\title{
32. EOCENE TO MIOCENE PALYNOLOGY OF THE NORWEGIAN SEA (ODP LEG 104) ${ }^{1}$
}

\author{
S. B. Manum, ${ }^{2}$ M. C. Boulter,${ }^{3}$ H. Gunnarsdottir, ${ }^{2}$ K. Rangnes,${ }^{2}$ and A. Scholze ${ }^{2}$
}

\begin{abstract}
Dinoflagellate cysts, pollen, and spores were studied from 78 samples of the Eocene to Miocene section of ODP Site 643 at the outer Vøring Plateau. Dinoflagellate cysts ranging from less than 1,000 to rarely over 30,000 per gram of sediment in the Paleogene, and generally between 50,000 and 100,000 in the Miocene were present. The shift to conspicuously higher cyst frequencies takes place in the lowermost Miocene section and appears to reflect increased cyst recruitment rather than a change in sedimentation rate. Of the 179 dinoflagellate cyst forms whose ranges were recorded, 129 are known species. Fifteen assemblage zones have been recognized, although the upper Eocene is missing and no substantial lower Eocene was recorded at Site 643. Norwegian Sea and Rockall Plateau zonations were compared with this study. Detailed correlation with existing onshore section zonations was difficult because key zonal species are inadequately represented; however, the middle to upper Miocene zonation established for Denmark is applicable.

Pollen and spores occur with relatively low frequencies, and palynodebris is generally absent, in contrast to the observations from DSDP Leg 38.

Thirty-nine samples from Eocene to Miocene sediments at Site 642 were studied and correlated with Site 643. A lower Eocene cyst assemblage present in Hole 642D is older than the questionably lower Eocene assemblage from Site 643. Site 642 has a lower Eocene to lower Miocene hiatus.
\end{abstract}

\section{INTRODUCTION}

Over the last few years there have been a number of contributions to the palynology of the Tertiary sediments from the Norwegian Sea. These include Manum (1976), Haaland (1981), Johnsen (1983), and Elde (1985) on the dinoflagellate cysts of DSDP Leg 38. Manum (1976) also presented a correlation of major changes in dinocyst/pollen ratios, (palynoevents; loc cit p. 905) for the Leg 38 sites. Koreneva et al. (1976) described the pollen and spore stratigraphy from Leg 38, and Boulter (1986) compared the pollen from Site 338 with that from marine Tertiary sections in the North Sea. Terrigenous and pelagic sources of palynodebris were analyzed from the Forties field in the North Sea by Boulter and Riddick (1986).

The spot coring practised on Leg 38 limited the usefulness of that material for biostratigraphic purposes. The continuous coring during Leg 104 increased considerably the palynological potential of these latter samples, and we have been able to make a much more detailed inventory of the palynomorphs than was possible with the material from Leg 38 .

This article reports our results and conclusions on Eocene to Miocene material from Site 642, Holes B, C, and D, and Site 643 (Fig. 1). The palynology of post-Miocene cores is dealt with by Mudie (this volume) who, as the shipboard palynologist, did the preliminary palynological study of the Leg 104 sites (Eldholm, Thiede, Taylor, et al., 1987). Detailed dinocyst work was carried out by H. Gunnarsdottir (Eocene), by K. Rangnes (Oligocene), and by A. Scholze (Miocene) who also prepared the zonation section for the Miocene. M. C. Boulter studied the pollen and spores from the entire sequence; K. Rangnes and $\mathrm{H}$. Gunnarsdottir did the quantitative work; S. B. Manum directed the project.

The major objectives of this article are: to establish the palynostratigraphy and provide a correlation for the Eocene to Mio-

\footnotetext{
${ }^{1}$ Eldholm, O., Thiede, J., Taylor, E. et al., 1989. Proc. ODP, Sci. Results, 104: College Station, TX (Ocean Drilling Program).

2 Department of Geology, University of Oslo, Oslo 3, Norway.

${ }^{3}$ Palynology Research Unit, North East London Polytechnic, London E15 4LZ, U.K.
}

cene parts of Sites 643 and 642, to compare the palynological data with other DSDP/ODP sites in the northern Atlantic and with onshore sections, and to identify palynoevents which might help with the interpretation of the Norwegian Sea geological history.

\section{MATERIAL AND METHODS}

\section{Sampling}

Our studies have been concentrated on Site 643 , as this was drilled with the principal objectives of establishing biostratigraphic and paleoenvironmental understanding. About 50 samples from Holes 642B to 642D were also examined to compare the two sections. More than 200 samples from 107 cores were processed, representing at least one sample per core from Holes $642 \mathrm{~B}$ to $642 \mathrm{D}$ and two to three samples per core from Hole 643 . Details of sampling positions for the various cores are given in Table 1. Results from separate studies of the deepest part of Site 642 , the intrabasaltic volcaniclastics from Hole $642 \mathrm{E}$, are reported in Boulter and Manum (this volume).

\section{Sample Processing}

Chemical processing was done as follows: (a) $10 \%$ cold $\mathrm{HCl}$ treatment for $1 \mathrm{hr}$, wash until neutral; (b) $40 \%-45 \%$ HF treatment at $70^{\circ} \mathrm{C}$ until all minerals are dissolved, directly followed by (c) $10 \% \mathrm{HCl}$ at $60^{\circ}-70^{\circ} \mathrm{C}$ until all fluorides are dissolved, centrifugation while still hot; (d) washing until neutral; (e) sieving through a $20-\mu \mathrm{m}$ metal sieve having circular holes (one slide was made at this stage); (f) oxidation of half the residue in fuming nitric acid for 0.5 to $1 \mathrm{~min}$, washing until neutral; $(\mathrm{g})$ sieving through the $20-\mu \mathrm{m}$ sieve and preparing at least four permanent slides.

\section{Preparation for Quantitative Analysis}

Studies on DSDP Leg 38 samples from the Norwegian Sea (Manum 1976) revealed changes through time in the marine to terrestrial palynomorph ratios and relative quantities of palynodebris at several sites, and these variations appeared to be corre- 


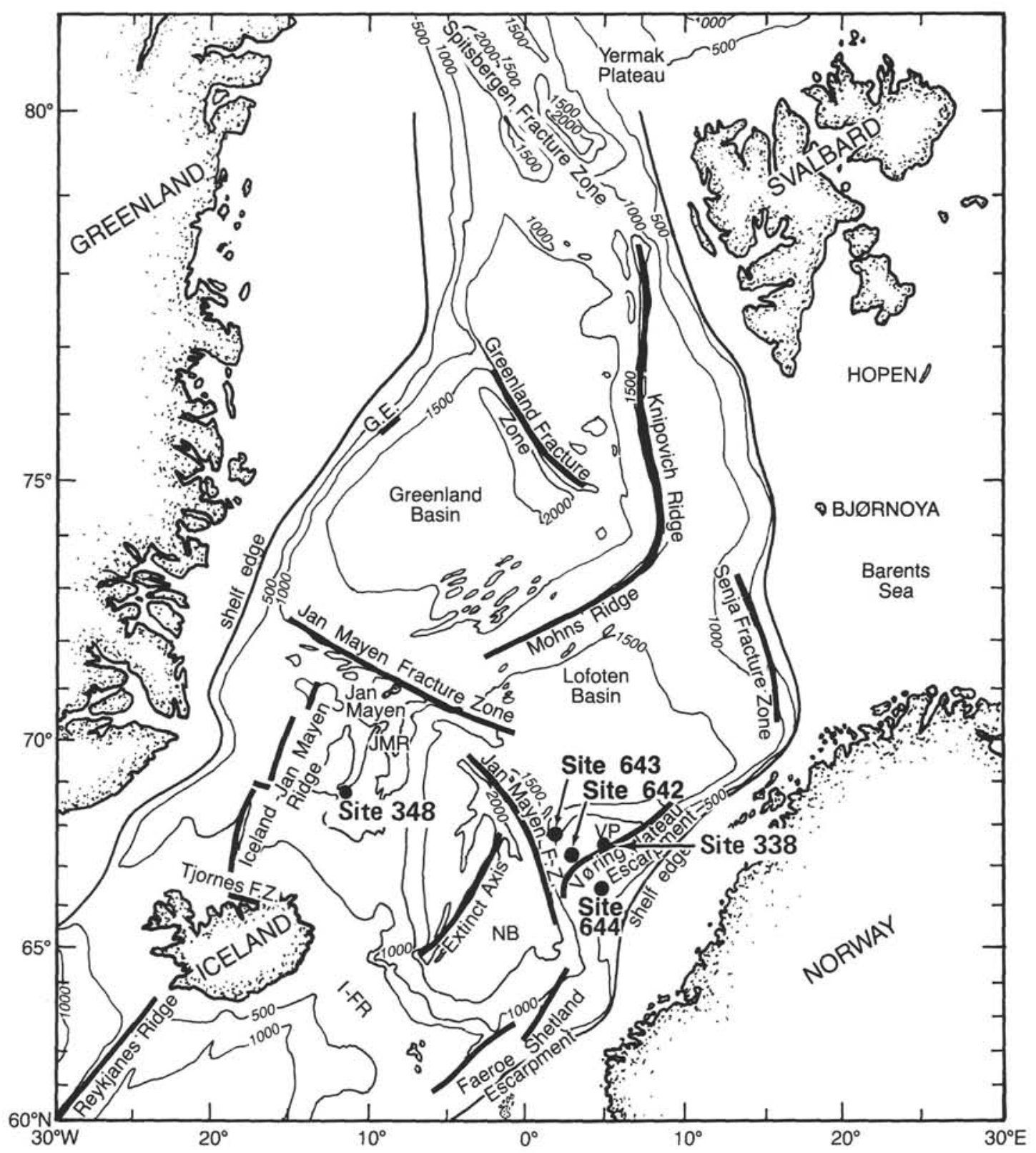

Figure 1. The Norwegian-Greenland Sea showing positions of ODP Leg 104 Sites 642, 643, and 644 and the DSDP Leg 38 Sites 338 and 348 used for correlation (Fig. 5).

latable events. However, Leg 38 material generated relative data only, as the task of processing samples within the short time available for initial reporting did not allow the use of absolute quantitative methods. So that palynomorph data may be related to other quantitative sediment parameters, we obtained absolute quantitative control of the palynomorph content in the sediments.

The method of adding a known number of Lycopodium spores to Quaternary samples to determine the absolute amount of pollen present was described by Stockmarr (1971). This method is widely used in Quaternary pollen analysis, but has rarely been attemped on pre-Quaternary material. Guidelines for application to the present material, particularly with respect to the amount of Lycopodium spores to be added, were gained from Haaland (1981) and Johnsen (1983) on Leg 38 material.
Samples consisting of 2 to $3 \mathrm{~cm}^{3}$ of core were weighed after air drying for $24 \mathrm{hr}$ in a drying cabinet. Then Lycopodium spores were added in the form of pills, each containing 12,077 $\pm 3.1 \%$ spores (supplier: Laboratory of Quaternary Biology, University of Lund, Sweden). Two pills added per gram of sediment yielded adequate results for most of the samples. Following the processing described in the section above, slides were produced by taking one drop of the thoroughly homogenized residue with a disposable pipette, mixing it with glycerol jelly on a slide, and sealing the preparation with wax after the cover slip was added.

Three slides from each sample were prepared in this way to provide an adequate number for counting. Counting was normally stopped at 300 palynomorphs (plus whatever number of Lycopodium spores were observed during the counting). Stock- 
Table 1. List of samples.

\begin{tabular}{|c|c|c|}
\hline $\begin{array}{c}\text { Core } \\
\text { section }\end{array}$ & $(\mathrm{cm})$ & $\begin{array}{l}\text { Depth } \\
\text { (mbsf) }\end{array}$ \\
\hline \multicolumn{3}{|l|}{642 B } \\
\hline $9-7$ & $50-52$ & 75.90 \\
\hline $11-5$ & $50-52$ & 91.90 \\
\hline $12-4$ & $59-61$ & 99.99 \\
\hline $13-5$ & $68-70$ & 110.88 \\
\hline $13-6$ & $68-70$ & 112.38 \\
\hline $15-1$ & $84-86$ & 124.34 \\
\hline $16-6$ & $74-76$ & 136.34 \\
\hline $17-6$ & $76-78$ & 146.26 \\
\hline $18-3$ & $77-79$ & 151.57 \\
\hline $19-6$ & $77-79$ & 165.97 \\
\hline $20-6$ & $83-85$ & 175.73 \\
\hline $21-6$ & $83-85$ & 185.43 \\
\hline $22-1$ & $67-70$ & 187.57 \\
\hline $23-3$ & 64-66 & 199.23 \\
\hline $24-1$ & $63-66$ & 206.23 \\
\hline $25-1$ & $63-66$ & 213.73 \\
\hline \multicolumn{3}{|l|}{$642 \mathrm{C}$} \\
\hline $10-1$ & $87-89$ & 64.37 \\
\hline $12-1$ & $78-80$ & 83.28 \\
\hline $14-1$ & $79-81$ & 102.29 \\
\hline $15-1$ & $79-81$ & 111.79 \\
\hline $17-1$ & $69-72$ & 130.69 \\
\hline $18-1$ & $81-84$ & 140.31 \\
\hline $19-3$ & $61-64$ & 152.61 \\
\hline $20-7$ & $67-70$ & 167.60 \\
\hline $21-6$ & $81-84$ & 176.31 \\
\hline $22-5$ & $67-70$ & 183.67 \\
\hline $23-2$ & $81-84$ & 186.61 \\
\hline $24-3$ & $81-84$ & 196.21 \\
\hline \multicolumn{3}{|l|}{$642 \mathrm{D}$} \\
\hline 2-6 & $80-82$ & 198.20 \\
\hline $3-2$ & $80-82$ & 201.90 \\
\hline $5-6$ & $80-82$ & 227.20 \\
\hline $6-5$ & $80-82$ & 235.30 \\
\hline $7-6$ & $80-82$ & 246.50 \\
\hline $8-6$ & $80-82$ & 256.10 \\
\hline $9-7$ & $27-30$ & 266.77 \\
\hline $10-5$ & $63-66$ & 273.73 \\
\hline $10-6$ & $63-66$ & 275.23 \\
\hline $11-1$ & $59-62$ & 277.39 \\
\hline $11-2$ & $59-62$ & 278.89 \\
\hline $12-1$ & $81-84$ & 287.31 \\
\hline $12-2$ & $81-84$ & 288.81 \\
\hline $12-3$ & $81-84$ & 290.31 \\
\hline $12-4$ & $84-87$ & 291.01 \\
\hline $12-5$ & $81-84$ & 293.31 \\
\hline $12-6$ & $81-84$ & 294.81 \\
\hline $13-1$ & $81-84$ & 297.09 \\
\hline $13-2$ & $81-84$ & 298.51 \\
\hline $13-3$ & $81-84$ & 300.01 \\
\hline $13-4$ & $81-84$ & 301.51 \\
\hline $14-1$ & $85-87$ & 306.65 \\
\hline $14-2$ & $85-87$ & 308.15 \\
\hline \multicolumn{3}{|l|}{$643 \mathrm{~A}$} \\
\hline $8-6$ & $48-50$ & 70.28 \\
\hline $9-5$ & $30-32$ & 78.10 \\
\hline $10-5$ & $31-33$ & 87.61 \\
\hline $11-5$ & $30-32$ & 97.10 \\
\hline $12-1$ & $31-33$ & 100.61 \\
\hline $12-4$ & $31-33$ & 105.11 \\
\hline $12-5$ & $31-33$ & 106.61 \\
\hline $13-6$ & $31-33$ & 117.61 \\
\hline $14-5$ & $32-34$ & 125.62 \\
\hline $15-6$ & $28-30$ & 136.58 \\
\hline $16-1$ & $30-32$ & 138.80 \\
\hline $18-1$ & $31-33$ & 157.81 \\
\hline $19-6$ & $30-32$ & 174.60 \\
\hline $20-6$ & $30-32$ & 184.20 \\
\hline $22-5$ & $30-32$ & 201.60 \\
\hline $23-5$ & $30-32$ & 211.40 \\
\hline $24-5$ & $30-32$ & 221.20 \\
\hline $25-2$ & $30-32$ & 226.50 \\
\hline
\end{tabular}

Table 1 (continued).

\begin{tabular}{|c|c|c|}
\hline $\begin{array}{c}\text { Core } \\
\text { section }\end{array}$ & $(\mathrm{cm})$ & $\begin{array}{l}\text { Depth } \\
\text { (mbsf) }\end{array}$ \\
\hline \multicolumn{3}{|c|}{642 A (Cont) } \\
\hline $25-6$ & $30-32$ & 232.50 \\
\hline $26-5$ & $30-32$ & 240.80 \\
\hline $27-5$ & $31-33$ & 250.61 \\
\hline $28-7$ & $30-32$ & 263.40 \\
\hline $29-6$ & $30-32$ & 271.70 \\
\hline $31-2$ & $30-32$ & 285.30 \\
\hline $32-1$ & $30-32$ & 293.60 \\
\hline $33-1$ & $53-54$ & 303.63 \\
\hline $34-2$ & $30-32$ & 314.70 \\
\hline $36-5$ & $30-32$ & 338.80 \\
\hline $37-3$ & $20-22$ & 345.50 \\
\hline $38-2$ & $29-31$ & 353.89 \\
\hline $39-1$ & $30-32$ & 362.10 \\
\hline $41-1$ & $18-20$ & 381.28 \\
\hline $42-1$ & $19-21$ & 390.89 \\
\hline $42-2$ & $19-21$ & 392.39 \\
\hline $42-3$ & $19-21$ & 393.89 \\
\hline $42-4$ & $19-21$ & 395.39 \\
\hline $44-1$ & $30-32$ & 410.50 \\
\hline $44-2$ & $30-32$ & 411.80 \\
\hline $44-3$ & $30-32$ & 413.30 \\
\hline $44-4$ & $30-32$ & 414.80 \\
\hline $44-6$ & $30-32$ & 417.80 \\
\hline $45-2$ & 29-31 & 421.49 \\
\hline $45-4$ & $29-32$ & 424.39 \\
\hline $45-5$ & 29-31 & 425.99 \\
\hline $46-1$ & $82-84$ & 430.22 \\
\hline $46-2$ & $82-84$ & 431.72 \\
\hline $46-5$ & $82-84$ & 436.22 \\
\hline $47-1$ & $90-92$ & 440.00 \\
\hline $47-3$ & $90-92$ & 443.00 \\
\hline $47-4$ & $90-92$ & 444.50 \\
\hline $47-5$ & $90-92$ & 446.00 \\
\hline $48-1$ & $90-92$ & 449.60 \\
\hline $48-3$ & $90-92$ & 452.60 \\
\hline $48-4$ & $90-92$ & 454.10 \\
\hline $48-5$ & $90-92$ & 455.60 \\
\hline $48-6$ & $90-92$ & 457.10 \\
\hline $49-1$ & $30-32$ & 458.70 \\
\hline $49-2$ & $30-32$ & 460.20 \\
\hline $49-3$ & $30-32$ & 461.70 \\
\hline $49-4$ & $30-32$ & 463.20 \\
\hline $50-1$ & $30-32$ & 468.40 \\
\hline $51-1$ & $30-32$ & 478.00 \\
\hline $51-2$ & $30-32$ & 479.50 \\
\hline $51-3$ & $30-32$ & 481.00 \\
\hline $51-4$ & $30-32$ & 482.50 \\
\hline $52-3$ & $28-30$ & 490.58 \\
\hline $52-4$ & $28-30$ & 492.08 \\
\hline 53-3 & $30-33$ & 500.30 \\
\hline $54-1$ & $30-32$ & 507.00 \\
\hline $54-5$ & $30-32$ & 513.00 \\
\hline $55-2$ & $30-32$ & 518.20 \\
\hline $55-5$ & $30-32$ & 522.70 \\
\hline $55-6$ & $30-32$ & 524.20 \\
\hline $56-2$ & $30-32$ & 527.80 \\
\hline $56-4$ & $30-32$ & 530.80 \\
\hline $57-4$ & $30-32$ & 540.40 \\
\hline $57-5$ & $30-32$ & 541.90 \\
\hline $60-2$ & $31-33$ & 556.71 \\
\hline
\end{tabular}

marr (1971) showed that the reliability of calculated absolute palynomorph contents is not significantly improved by counting higher numbers. The number of indigenous palynomorphs per gram of samples $(\mathrm{P})$ is calculated by using the formula:

$\mathrm{P}=\frac{\text { Lycopod } \text {. spores added to sample } \times \text { indig. palynomorphs counted }}{\text { weight of sample (grams) } \times \text { Lycopod } \text {. spores counted }}$

Our quantitative method has not been subject to extensive tests to verify its reliability. However, an indicator of the success of our method is comparison of the results of counting from Holes 642B and 642C (Fig. 2). These holes were drilled a few 
tens of meters apart through identical sequences. The counts produced consistently similar diagrams for palynomorph frequencies in $1 \mathrm{~g}$ of sediment, indicating that the errors inherent in the method are negligible. In Figure 2, comparison is also made with total organic carbon (TOC) analysis data (Henrich et al., this volume). There is fairly good agreement between our absolute counts and TOC values (TOC values and palynomorph counts are not from identical samples, and TOC sampling is much denser).

The processing residues are always rich in amorphous matter which can be removed by oxidation. Previous experience (Johnsen, 1983) shows that the oxidation process selectively removes or destroys the Lycopodium spores and thus invalidates the quantitative control. However, oxidation for less than $1 \mathrm{~min}$ has proved to be satisfactory.

\section{Taxonomic Approach}

Approximately 250 dinocyst species were recorded, approximately half of which can be referred to described taxa. The new taxa we use are not described here but are dealt with informally. Brief, preliminary descriptions of new taxa are available from either the authors or from the Ocean Drilling Program on floppy disk (MS-DOS, Wordstar) or printout. Our nomenclature for most of the known taxa follows Lentin and Williams' (1985) index of dinocyst genera and species. We have therefore omitted taxonomic authorships in the text and instead refer to that index for this taxonomic and bibliographic information. Our alphabetic species index (Table 2) gives information on the few taxa used here that are not indexed in Lentin and Williams (1985).

For reasons outlined in the Appendix to Boulter and Manum (this volume), a simple and informal nomenclature system has been adopted for pollen and spores, based on two words which convey something of their morphological character. Formal taxonomic treatment must wait until a full comparative study can be made.

\section{DINOFLAGELLATE CYST ZONATION: SITE 643}

The zonation presented here is based on the semiquantitative records of dinocyst distribution for Site 643 as presented in Figures $3 \mathrm{~A}$ and $3 \mathrm{~B}$. A summary of the ranges of the stratigraphically most significant taxa on which the zonation is based is presented in Figures 4A and 4B. An alphabetic index to assist in locating the individual taxa in range charts and plates is presented in Table 2. The stratigraphic resolution varies with our sampling density, which in the Eocene is 2 to 4 samples per core; in the Oligocene, 3 to 5 samples per core; and in the Miocene, 1 to 2 samples per core (Table 1).

Existing zonation schemes are difficult to use because their key species are inadequately represented. However, we have been able to apply Piasecki's (1980) zonation for the middle and upper Miocene. The Leg 104 shipboard zonation (Eldholm, Thiede, Taylor, et al., 1987) is also difficult to use, partly because it is based on Site 642 material, which is less complete than the Site 643 material we have used, and partly because of taxonomic differences. The tentative scheme proposed by Manum (1976) for DSDP Site 338 in the Vøring Plateau was based on 57 cyst taxa, many of which were informally named. Some of the taxa which appeared to be important for Manum's (1976) zonation are insufficiently represented in our new material. Also, there appear to be considerable differences between Sites 338 and 643 in the portions of the stratigraphic column that are preserved or missing.

The cysts from Site 643 have been recorded in greater detail than was possible for the Leg 38 material. Of the more than 250 cyst taxa recorded from 78 samples, our range charts (Figs. 3A and 3B) include only 179 taxa; taxa with rare occurrence in a single sample are not included.

\section{Eocene Section}

The Eocene is recognized from Sections 104-643A-60-2 to $-643 \mathrm{~A}-51-1$. The scarcity of species of the Wetzeliellaceae prevents the application of the Paleogene zonation established by Costa and Downie (1976; revised version in Williams and Bujak 1985: 883).

The scarcity of stratigraphically diagnostic representatives of this cyst family was also evident in Leg 38 material (Manum 1976), as well as in the correlatable sequences from Leg 48 (Rockall Plateau; Costa and Downie, 1979).

Only a few taxa from the Eocene section are sufficiently restricted to be useful in dating. The lowermost sample studied (Section 104-643A-60-2), has species whose ranges include the lower Eocene and younger (i.e., Achilleodinium biformoides, Diphyes colligerum, Eatonicysta ursulae, Palaeocystodinium golzowense, Samlandia chlamydophora, Thalassiphora pelagica, and Wetzeliella articulata). None of the recorded species from the lowermost sample indicate a conclusively lower Eocene dating. Rottnestia borussica occurs only in this sample, as does Eatonicysta ursulae, whose range is shown by Williams and $\mathrm{Bu}-$ jak (1985) to be restricted to the upper part of the middle Eocene, corresponding to the range documented in southern England (Bujak et al., 1980: Barton Beds). However, there are also records of this species from the lower Eocene (e.g., Morgenroth, 1966; Costa and Downie, 1979).

Adnatosphaeridium vittatum and Areosphaeridium diktyoplokus both first appear in Section 104-643A-57-5. Williams and Bujak (1985) show A. vittatum to be restricted to the lower Eocene, and $A$. diktyoplokus to appear first at the very top of the lower Eocene. In the Bracklesham Beds, however, these species are associated in what appears to be the middle Eocene (Zones B2-B4 of Bujak et al., 1980). Costa and Downie (1979) reported $A$. vittatum from lower Eocene sediments only from the Rockall Plateau, and its range did not overlap that of $A$. diktyoplokus. Thus, we find no conclusive support for an early Eocene age for Section 104-643A-57-5 either, and favor assigning a middle Eocene age to this sample. This is supported by the occurrence in a slightly higher sample, in Section 104-643A-574 , of Corrudinium incompositum, which appeared in the middle Eocene in the North Sea (Ioakim, 1979). Williams and Bujak (1985) indicate a mid-middle Eocene first appearance for this species.

Species diagnostic of upper Eocene sediments were not found. One species, Heteraulacacysta porosa, recorded from Section 104-643A-51-1, has a known range restricted to mid-middle Eocene (NP16 equivalent, according to Williams and Bujak, 1985), and would therefore appear to exclude any upper Eocene sediments up to this level. Other species having their first appearances from Sections 104-643A-57-5 to -643-51-1 all have known ranges from at least as early as middle Eocene.

On this basis, we conclude that the entire section Sections 104-643-60-2 to -643-51-1 is middle Eocene, with the reservation that for Section 104-643-60-2 an early Eocene age seems possible. The upper Eocene appears to be missing at Site 643 .

\section{Rottnestia borussica Zone (Section 104-643A-60-2 only), lower?/middle Eocene}

Interval from our lowest sample Section 104-643A-60-2 to lowest appearance of Adnatosphaeridium vittatum.

Other species: Highest appearance of Rottnestia borussica and Eatonicysta ursulae is within the zone; Wetzeliella articulata is abundant.

Comparison: $R$. borussica, $E$. ursulae, and $W$. articulata are associated in the Rockall Zone IV (Costa and Downie, 1979); $R$. 


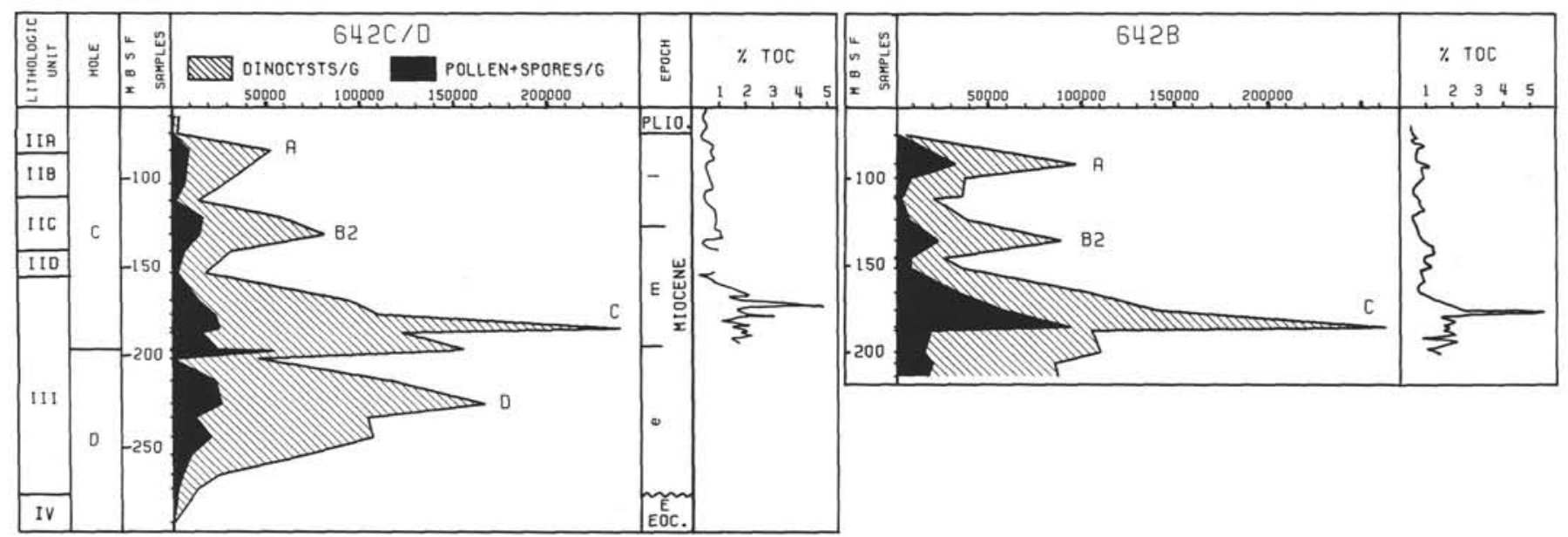

Figure 2. Graphical presentation of absolute frequency counts of marine (dinocysts) and terrestrial (pollen and spores) palynomorphs for Holes $642 \mathrm{C} / \mathrm{D}$ and $642 \mathrm{~B}$, and total organic carbon (TOC) values (from Henrich et al., this volume). The palynological maxima B-D correlate with results from Site 643, shown in Figure 7.

borussica and $W$. articulata were both reported from Zone VI (but not in association) in material from Leg 38 (Manum 1976).

(Interval Sections 104-643A-60-2 to -643A-57-7: one sample from 59-1 barren; no sediment recovery from Core 104-643A-58.)

\section{Adnatosphaeridium vittatum Zone (Sections 104-643A-57-5 to -643A-54-1), middle Eocene}

Interval from lowest appearance of Adnatosphaeridium vittatum to lowest appearance of Deflandrea sp. B.

Other species: Areosphaeridium diktyoplokus and Corrudinium incompositum have their lowest appearance within the zone (the former from the base of the zone). Cerebrocysta bartonensis and Phthanoperidinium geminatum are restricted to the zone.

Comparison: $C$. incompositum and $P$. geminatum are both associated in the Barton Beds (Bujak et al., 1980). At least the upper part of this zone would seem to compare with the Barton Bed Zones 1-5 (NP16-NP17 equivalent, Williams and Bujak, 1985).

Deflandrea sp. B Zone (Sections 104-643A-53-3 to -643-52-3), middle Eocene

Interval from lowest appearance of Deflandrea sp. B to lowest appearance of Areosphaeridium arcuatum.

Other species: Araneosphaera araneosa has its lowest appearance at the base of zone; Glaphyrocysta sp. 1 is commonto-abundant in the upper part.

\section{Areosphaeridium arcuatum Zone (Sections 104-643-51-4 to -643A-51-1), middle Eocene}

Interval from lowest appearance of Areosphaeridium arcuatum to lowest appearance of Chiropteridium lobospinosum.

Other species: Areosphaeridium pectiniforme, Nematosphaeropsis sp. 2, and Distatodinium ellipticum are restricted to this zone. Distatodinium craterum has its lowest appearance within this zone.

(This zone marks the top of the Eocene sequence at Site 643, and our results consequently indicate that the entire upper Eocene is missing.)

\section{Eocene/Oligocene Boundary}

This boundary is placed between the samples from Sections 104-643A-51-1 and -643A-49-4, between the highest occurrence of Areosphaeridium pectiniforme and Distatodinium ellipticum in Section 104-643A-51-1 and the lowest occurrence of Chiropteridium lobospinosum and Heteraulacacysta campanula in Section 104-643A-49-4. Between these two samples there is an undiagnostic sample from Section 104-643A-50-1, which lacks critical species of either Eocene or Oligocene sediments; the only species of stratigraphic significance recovered from it is Svalbardella cooksoniae, whose known range is upper Eocene to lower Oligocene. In the absence of other evidence for the upper Eocene, this sample is included in the Oligocene section. Unfortunately, Core 104-643A-50, which appears to be critical for the definition of the Eocene/Oligocene boundary, has poor sediment recovery. This boundary can therefore not be checked more closely.

\section{Oligocene}

\section{Chiropteridium lobospinosum Zone (Sections 104-643A-50-1 to $-643 A-48-6$ ), lower Oligocene}

Interval from lowest appearance of Chiropteridium lobospinosum to highest appearance of Areosphaeridium arcuatum. (The undiagnostic sample from Section 104-643A-50-1 is included in this zone by implication; see Eocene/Oligocene boundary discussion.)

Other species: The distinctive Spiniferites forms designated "sp. 1" and "sp. 2" are restricted to this zone and are commonto-abundant through parts of the interval. Gelatia sp. 1 and Dinocyst 3 (Evittosphaerula? sp. 1), are two other distictive forms which are common at the top of the zone, the latter ranging into the lower part of the zone above. Svalbardella cooksoniae is common in the otherwise undiagnostic sample from Section 104-643A-50-1 and has not been recovered from other samples at Site 643 .

Comparison: The presence of Areosphaeridium arcuatum indicates an early Oligocene age for this zone (Williams and $\mathrm{Bu}-$ jak, 1985).

\section{Areosphaeridium? actinocoronatum Zone (Sections 104-643A-48-5 to -643A-47-1), lower/upper Oligocene}

Interval from highest appearance of Areosphaeridium arcuatum to lowest appearance of Impagidinium sp. 1. (Samples from Sections 104-643A-48-5 to -643A-47-5 yield few and undiagnostic cysts and are included in this zone tentatively.) 
Table 2. Alphabetical listing of dinocyst taxa referring to the numerical indexes in Figures 3-5 and to Plates 1-20.

\begin{tabular}{|c|c|c|c|c|c|c|c|}
\hline & \multicolumn{2}{|c|}{ LO ${ }^{643} \mathrm{HI}$} & \multirow{2}{*}{\begin{tabular}{|l}
$642 \mathrm{C}$ \\
FIG. 6 \\
\end{tabular}} & \multirow{2}{*}{\begin{tabular}{|c|}
$642 \mathrm{D}$ \\
TABLE 3 \\
\end{tabular}} & \multicolumn{2}{|c|}{ LO ZONES HI } & \multirow[t]{2}{*}{ PLATE/FIG. } \\
\hline & FIG. $3 \mathrm{~A}$ & FIG. 3B & & & FIG. $4 \mathrm{~A}$ & FIG. 4B & \\
\hline Achilleodinium biformoides & 1 & 134 & & & 1 & 47 & $2 / 3$ \\
\hline Achomosphaera andalousiensis & 170 & 1 & 11 & 59 & 68 & 1 & $2 / 4$ \\
\hline Achomosphaera ramulifera & & & 12 & & & & $3 / 8$ \\
\hline Achomosphaera sp. 1 & 176 & 2 & & & & & $2 / 1-2$ \\
\hline Achomosphaera spp. & 2 & 97 & & 7 & & & \\
\hline Adnatosphaeridium robustum & 27 & 174 & & & & & $2 / 11-12$ \\
\hline Adnatosphaeridium vittatum & 15 & 155 & & & 6 & 59 & $2 / 7-8$ \\
\hline Aireiana sp. 1 & 58 & 146 & & & & & $1 / 4$ \\
\hline Amiculosphaera umbracula & & & 1 & & & & $1 / 6-7$ \\
\hline Amiculosphaera cf. umbracula & 177 & 3 & 26 & & & & $1 / 5$ \\
\hline Apectodinium homomorphum & & & & 100 & & & \\
\hline Apectodinium quinquelatum & & & & 101 & & & \\
\hline Apeotodinium spp. & & & & 80 & & & \\
\hline Apteodinium australiense & 32 & 99 & & 8 & 11 & 32 & $3 / 1$ \\
\hline Apteodinium teotatum & 103 & 53 & 71 & & & & $2 / 5-6$ \\
\hline Araneosphaera cf. araneosa & 45 & 148 & & & 12 & 56 & $3 / 4$ \\
\hline Areoligera sp. 1 & 63 & 132 & & & 25 & 46 & $1 / 3$ \\
\hline Areosphaeridium? actinocoronatum & 71 & 38 & 13 & 39 & 29 & 7 & $3 / 2$ \\
\hline Areosphaeridium arouatum & 49 & 141 & & & 15 & 51 & $1 / 1$ \\
\hline Areosphaeridium diktyoplokus & 16 & 156 & & & 7 & 60 & $3 / 3$ \\
\hline Areosphaeridium fenestratum & & & & 81 & & & \\
\hline Areosphaeridium pectiniforme & 50 & 149 & & & 16 & 57 & $1 / 2$ \\
\hline Ascostomocystis granosa Matsuoka 1983 & 88 & 63 & 64 & 62 & 40 & 20 & $3 / 5$ \\
\hline Batiacasphaera baculata & 94 & 108 & & 9 & & & $1 / 8-9$ \\
\hline Batiacasphaera hirsuta & 95 & 27 & 27 & 10 & & & $3 / 6$ \\
\hline Batiacasphaera micropapillata & 68 & 113 & & 11 & & & $4 / 1-4$ \\
\hline Batiacasphaera cf. scrobiculata & 3 & 160 & & & & & \\
\hline Batiacasphaera sphaerica & 100 & 39 & 14 & 12 & 46 & 8 & $1 / 10$ \\
\hline Batiacasphaera sp. 1 & 99 & 100 & 76 & 52 & & & $1 / 11$ \\
\hline Batiacasphaera sp. 2 & 171 & 64 & 77 & 40 & & & $1 / 12-14$ \\
\hline Bitectatodinium tepikiense & & & 2 & & & & $2 / 9$ \\
\hline Bitectatodinium? sp. 1 & 111 & 103 & & 13 & 50 & 34 & $4 / 11-12$ \\
\hline Caligodinium amiculum & 87 & 123 & & 74 & & & $4 / 7$ \\
\hline Cannosphaeropsis utinensis & 124 & 72 & 55 & & & & $4 / 5-6$ \\
\hline Cannosphaeropsis sp. A of Costa \& Downie 1979 & 104 & 65 & 72 & 66 & & & $4 / 13-14$ \\
\hline Cannosphaeropsis sp. 1 & 20 & 175 & & & & & $4 / 8$ \\
\hline Cannosphaeropsis sp. 2 & 35 & 171 & & & & & $4 / 9-10$ \\
\hline Cerebrocysta bartonensis & 28 & 161 & & 82 & 9 & 63 & $2 / 10$ \\
\hline Chiropteridium lobospinosum & 59 & 131 & & & 21 & 45 & $5 / 1$ \\
\hline Chiropteridium mespilanum & 86 & 125 & & & 39 & 42 & $5 / 2-3$ \\
\hline Chiropteridium partispinatum & 72 & 126 & & & 30 & 43 & \\
\hline Cleistosphaeridium sp. 1 & 157 & 40 & 15 & & & & $3 / 10-11$ \\
\hline Cordosphaeridium cantharellum & 48 & 104 & & 41 & 14 & 35 & $6 / 1$ \\
\hline
\end{tabular}


Table 2 (continued).

\begin{tabular}{|c|c|c|c|c|c|c|c|}
\hline & \multicolumn{2}{|c|}{$\mathrm{LO}^{643} \mathrm{HI}$} & \multirow{2}{*}{$\begin{array}{l}642 \mathrm{C} \\
\text { FIG. } 6 \\
\end{array}$} & \multirow{2}{*}{\begin{tabular}{|c|}
$642 \mathrm{D}$ \\
TABLE 3 \\
\end{tabular}} & \multicolumn{2}{|c|}{$\begin{array}{c}643 \mathrm{~A} \\
\text { LO ZONES HI }\end{array}$} & \multirow[t]{2}{*}{ PLATE/FIG. } \\
\hline & FIG. $3 \mathrm{~A}$ & FIG. $3 \mathrm{~B}$ & & & FIG. $4 \mathrm{~A}$ & FIG. 4B & \\
\hline Cordosphaeridium inodes & 4 & 165 & & & & & $6 / 2$ \\
\hline Cordosphaeridium sp. I of Manum 1976 & 152 & 73 & 57 & & 65 & 22 & $5 / 4$ \\
\hline Corrudinium incompositum & 21 & 157 & & & 8 & 61 & $4 / 15$ \\
\hline Corrudinium sp. 1 & 149 & 70 & & & & & $15 / 8-9$ \\
\hline Cribroperidinium giuseppei & 5 & 162 & & 83 & & & $5 / 5$ \\
\hline Cribroperidinium giuseppei major & 148 & 87 & & 63 & & & $5 / 6-7$ \\
\hline Cribroperidinium tenuitabulatum & 105 & 92 & & 42 & 48 & 29 & $5 / 8-9$ \\
\hline Danea manicata & 36 & 166 & & & & & $6 / 4$ \\
\hline Dapsitidinium pastielsii & 106 & 4 & 39 & 14 & & & $9 / 1$ \\
\hline Dapsilidinium pseudocolligerum & 91 & 88 & 65 & & & & $9 / 2$ \\
\hline Dapsitidinium sp. 1 & 158 & 93 & & 15 & & & $9 / 3$ \\
\hline Deflandrea oebisfeldensis & & & & 84 & & & \\
\hline Deflandrea phosphoritica & 22 & 139 & & 85 & & & $9 / 4-6$ \\
\hline Deflandrea sp. B of Powell 1986 & 46 & 137 & & & 13 & 48 & $9 / 7$ \\
\hline Dinocyst 1 & 23 & 176 & & & & & $8 / 1-2$ \\
\hline Dinocyst 2 & 37 & 167 & & & & & $6 / 5-6$ \\
\hline Dinocyst 3 (Evittosphaerula? sp. 1) & 64 & 140 & & & 26 & 50 & $8 / 3-4$ \\
\hline Dinocyst 4 & 138 & 109 & & & & & $8 / 5-7$ \\
\hline Dinocyst 5 & 139 & 105 & & 43 & & & $8 / 14-15$ \\
\hline Dinocyst 6 & 140 & 80 & 58 & & 61 & 26 & $8 / 8-9$ \\
\hline Dinocyst 7 & 153 & 74 & 73 & & & & $8 / 10-11$ \\
\hline Dinocyst 8 & & & & 86 & & & \\
\hline Dinocyst II of Manum 1976 & 96 & 107 & 40 & 16 & & & $8 / 12$ \\
\hline Dinocyst IV of Manum 1976 & 125 & 114 & & 17 & & & $8 / 13$ \\
\hline Dinopterygium cladoides sensu Morgenroth 1966 & 43 & 110 & & 53 & & & $9 / 10$ \\
\hline Diphyes colligerum & & & & 102 & & & \\
\hline Diphyes cf. cotligerum & 6 & 172 & & & 2 & 65 & $9 / 8$ \\
\hline Diphyes sp. 1 & 38 & 168 & & & & & $9 / 9$ \\
\hline Distatodinium craterum & 52 & 111 & & 75 & 18 & 37 & $7 / 2$ \\
\hline Distatodinium ellipticum & 54 & 150 & & & 19 & 58 & $7 / 1$ \\
\hline Distatodinium paradoxum & 74 & 81 & 16 & 44 & 32 & 27 & $7 / 3$ \\
\hline Eatonicysta ursulae & 7 & 177 & & 87 & 3 & 67 & $6 / 3$ \\
\hline Emslandia spiridoides & 81 & 94 & & 18 & 37 & 30 & $3 / 12-13$ \\
\hline Evittosphaerula paratabulata & 113 & 112 & & 54 & 52 & 38 & $6 / 7$ \\
\hline Evittosphaerula? sp. 2 & & & 33 & & & & $7 / 8-10$ \\
\hline Filisphaera filifera & 167 & 41 & 3 & & & & $9 / 11-12$ \\
\hline Gelatia sp. 1 & 65 & 142 & & & 27 & 52 & $6 / 8-9,7 / 6-$ \\
\hline Gen. et sp. indet. of Piasecki 1980 & 164 & 54 & 41 & & & & $10 / 1-3$ \\
\hline Glaphyrocysta intricata & 24 & 133 & & & & & $7 / 4$ \\
\hline Glaphyrocysta ordinata & & & & 88 & & & \\
\hline Glaphyrocysta cf. vioina & 47 & 144 & & & & & $7 / 5$ \\
\hline Glaphyrocysta spp. & 25 & 135 & & & & & \\
\hline Hafniasphaera spp. & & & & 105 & & & \\
\hline Heteraulacacysta campanula & 60 & 55 & & 19 & 22 & 16 & $6 / 11-13$ \\
\hline Heteraulacacysta porosa & 56 & 151 & & & & & $6 / 14$ \\
\hline
\end{tabular}


Table 2 (continued).

\begin{tabular}{|c|c|c|c|c|c|c|c|}
\hline & \multicolumn{2}{|c|}{$\mathrm{LO}^{643} \mathrm{HI}$} & \multirow{2}{*}{$\begin{array}{l}642 \mathrm{C} \\
\text { FIG. } 6\end{array}$} & \multirow{2}{*}{$\begin{array}{c}642 \mathrm{D} \\
\text { TABLE } 3\end{array}$} & \multicolumn{2}{|c|}{$\begin{array}{r}643 \mathrm{~A} \\
\text { LONES } \mathrm{HI}\end{array}$} & \multirow[t]{2}{*}{ PLATE/FIG. } \\
\hline & FIG. $3 \mathrm{~A}$ & FIG. $3 B$ & & & FIG. $4 \mathrm{~A}$ & FIG. $4 \mathrm{~B}$ & \\
\hline Homotryblium floripes & 75 & 95 & 59 & & 33 & 31 & $10 / 6-7$ \\
\hline Homotryblium vallum & 150 & 56 & 34 & 60 & & & $10 / 8$ \\
\hline Hystrichokolpoma cinctum & 82 & 117 & & & & & $13 / 3$ \\
\hline Hystrichokolpoma rigaudiae & 76 & 5 & 28 & 55 & 34 & 2 & $13 / 4$ \\
\hline Hystrichokolpoma sp. 1 & 8 & 178 & & & & & \\
\hline Hystrichokolpoma? sp. 2 & 112 & 115 & & & 51 & 39 & $13 / 1-2$ \\
\hline Hystrichokolpoma sp. 3 & & & & 89 & & & \\
\hline Hystricosphaeridium latirictum & 77 & 42 & 74 & 70 & 35 & 9 & $10 / 9-10$ \\
\hline Hystricosphaeridium tubiferum & & & & 90 & & & \\
\hline Hystricosphaeridium sp. 1 & 130 & 98 & & 20 & & & $10 / 13-14$ \\
\hline Hystrichosphaeropsis cf. complanata & 131 & 43 & & & & & $11 / 4-5$ \\
\hline Hystrichosphaeropsis obscura & 107 & 6 & 17 & & 49 & 3 & $11 / 1-2$ \\
\hline Hystriohosphaeropsis sp. 1 & 33 & 169 & & & & & $11 / 3$ \\
\hline Hystrichostrogylon cf. membraniphorum & 168 & 66 & 60 & & & & $10 / 11$ \\
\hline Hystrichostrogylon sp, of Edwards 1984 & 151 & 68 & 42 & & & & $10 / 12$ \\
\hline Hystrichostrogylon sp. 1 & 161 & 67 & & & & & $13 / 11-13$ \\
\hline Impagidinium aculeatum & 73 & 44 & 2 & & 31 & 10 & $17 / 9$ \\
\hline Impagidinium aquaeductum & 166 & 71 & 66 & & 67 & 21 & $11 / 6-7$ \\
\hline Impagidinium japonicum & 154 & 28 & & 64 & & & $12 / 1$ \\
\hline Impagidinium maculatum & 163 & 82 & 29 & 71 & & & $11 / 10-11$ \\
\hline Impagidinium pallidum & 92 & 29 & 18 & 72 & & & $17 / 10$ \\
\hline Impagidinium paradoxum & 117 & 45 & 43 & 21 & 54 & 11 & $11 / 9$ \\
\hline Impagidinium patulum & 141 & 46 & 19 & 45 & 62 & 12 & $17 / 3-4$ \\
\hline Impagidinium velorum & 39 & 33 & 67 & 23 & & & $11 / 8$ \\
\hline Impagidinium sp. 1 & 78 & 116 & & 73 & 36 & 40 & $17 / 7-8$ \\
\hline Impagidinium sp. 2 & 101 & 30 & 4 & 65 & & & $11 / 12-14$ \\
\hline Impagidinium sp. 3 & 114 & 31 & 44 & & & & $12 / 2-4$ \\
\hline Impagidinium sp. 4 & 146 & 83 & & & & & $12 / 5-6$ \\
\hline Impagidinium spp. & 17 & 32 & 35 & 22 & & & \\
\hline Impletosphaeridium spp. & 66 & 34 & 6 & 46 & & & \\
\hline Invertocysta lacrymosa & 172 & 7 & 20 & & & & $10 / 15$ \\
\hline Invertocysta tabulata & 89 & 84 & 68 & 76 & 41 & 28 & $10 / 16$ \\
\hline Invertocysta? sp. 1 & 126 & 118 & & & & & $3 / 9$ \\
\hline Kissetovia coleothrypta & & & & 91 & & & \\
\hline Labyrinthodinium truncatum & 165 & 47 & 46 & & 66 & 13 & $12 / 7-8$ \\
\hline Labyrinthodinium of truncatum & 142 & 8 & 45 & & 63 & 4 & $12 / 9-10$ \\
\hline Lanternosphaeridium lanosum & & & & 106 & & & \\
\hline Lejeunecysta fallax & 108 & 48 & & 56 & & & $10 / 5$ \\
\hline Lejeunecysta of. hyalina & 132 & 76 & & & & & $10 / 4$ \\
\hline Lejeunecysta spp. & & & & 78 & & & \\
\hline Lentinia serrata & & & & 92 & & & \\
\hline Lentinia wetzelii & & & & 93 & & & \\
\hline Leptodinium? sp. III of Manum 1976 & 118 & 120 & & 67 & & & $12 / 14-15$ \\
\hline Lingulodinium machaerophorum & 34 & 9 & 6 & 24 & & & $15 / 1-2$ \\
\hline
\end{tabular}


Table 2 (continued).

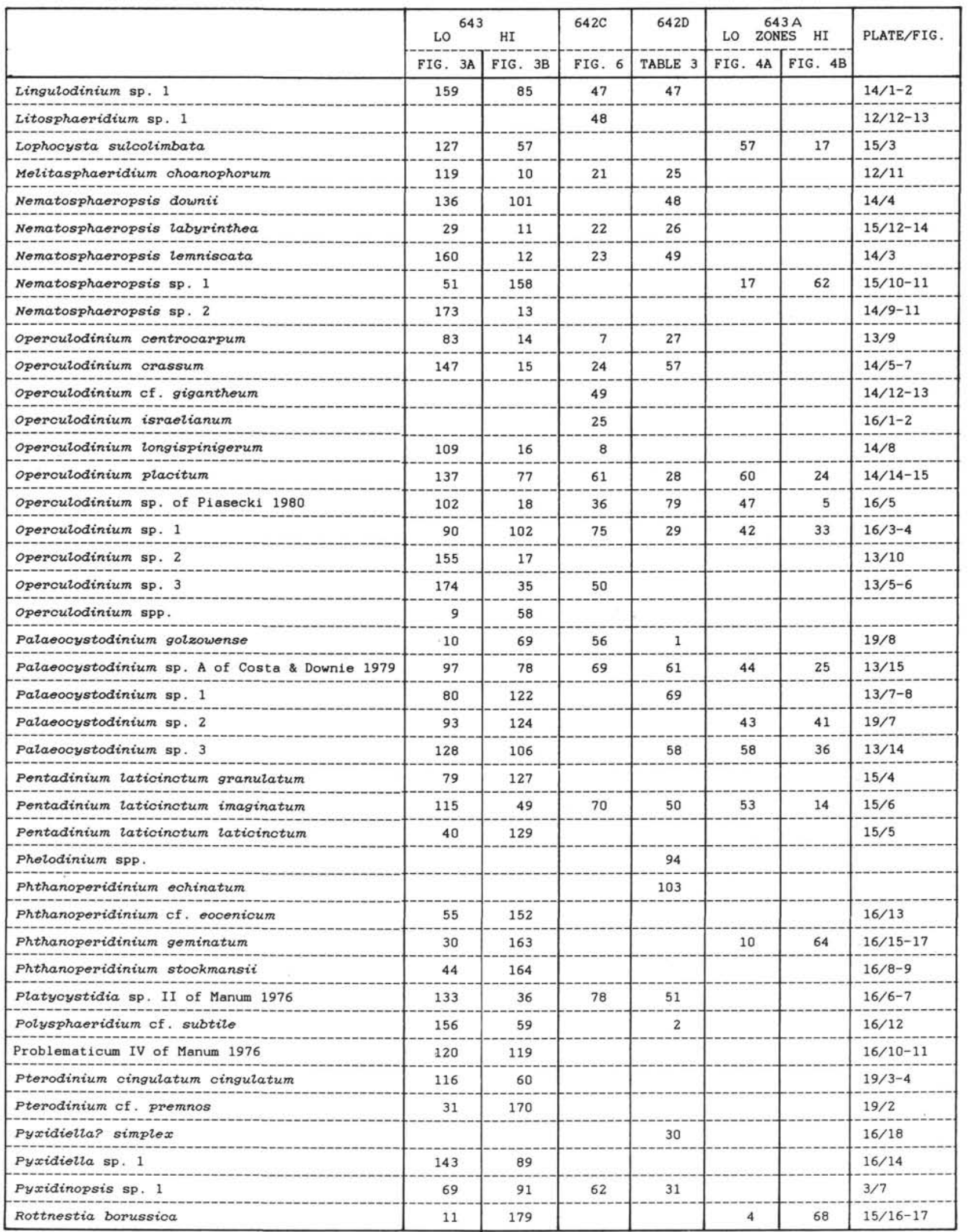


Table 2 (continued).

\begin{tabular}{|c|c|c|c|c|c|c|c|}
\hline & \multicolumn{2}{|c|}{ LO ${ }^{643} \mathrm{HI}$} & \multirow{2}{*}{$\begin{array}{l}642 \mathrm{C} \\
\text { FIG. } 6 \\
\end{array}$} & \multirow{2}{*}{$\begin{array}{c}642 \mathrm{D} \\
\text { TABLE } 3 \\
\end{array}$} & \multicolumn{2}{|c|}{$\begin{array}{c}643 \\
\text { LO } \\
\text { ZONES HI }\end{array}$} & \multirow[t]{2}{*}{ PLATE/FIG. } \\
\hline & FIG. $3 \mathrm{~A}$ & FIG. $3 B$ & & & FIG. $4 \mathrm{~A}$ & FIG. $4 \mathrm{~B}$ & \\
\hline Samlandia chlamydophora & 12 & 159 & & 95 & & & $15 / 7$ \\
\hline Samlandia sp. 1 & 70 & 138 & & & 28 & 49 & $15 / 15$ \\
\hline Selenopemphix nephroides & 144 & 79 & & 77 & & & $19 / 5$ \\
\hline Spiniferites bentorii & 178 & 19 & 51 & & & & $19 / 11$ \\
\hline Spiniferites elongatus & 179 & 20 & & & & & $19 / 1$ \\
\hline Spiniferites hyperacanthus & 67 & 90 & & & & & $19 / 10$ \\
\hline Spiniferites of. mirabilis & 110 & 50 & 52 & 32 & & & $19 / 9$ \\
\hline Spiniferites pseudofurcatus & 18 & 21 & 53 & 33 & & & $17 / 1$ \\
\hline Spiniferites ramosus-group & 41 & 22 & 9 & 34 & & & $18 / 1-4,8$ \\
\hline Spiniferites ramosus brevifurcatus & 134 & 86 & 63 & 3 & & & \\
\hline Spiniferites sp. 1 & 61 & 145 & & & 23 & 54 & $17 / 5$ \\
\hline Spiniferites sp. 2 & 62 & 143 & & & 24 & 53 & $17 / 2$ \\
\hline Spiniferites sp. 3 & 85 & 128 & & & & & $19 / 12-13$ \\
\hline Spiniferites sp. 4 & 175 & 23 & & & & & $18 / 5-7$ \\
\hline Spiniferites spp. & 19 & 24 & 10 & 4 & & & \\
\hline Sumatradinium? sp. C of Powe11 1986 & 121 & 61 & 30 & 35 & 55 & 18 & $20 / 12,15$ \\
\hline Sumatradinium? sp. D of Powell 1986 & 122 & 62 & & & 56 & 19 & $20 / 14$ \\
\hline Svalbardella cooksoniae & 57 & 147 & & & 20 & 55 & $19 / 6$ \\
\hline Systematophora placacantha & 26 & 37 & 31 & 5 & & & $18 / 9-10$ \\
\hline Systematophora sp. 1 & 84 & 130 & & & 38 & 44 & $18 / 11-13$ \\
\hline Tanyosphaeridium sp. I of Manum 1976 & 123 & 121 & & & & & $20 / 10$ \\
\hline Tectatodinium psilatum & 129 & 25 & & 36 & 59 & 6 & $20 / 1,5$ \\
\hline Tectatodinium sp. I of Manum 1976 & & & & 104 & & & \\
\hline Tectatodinium sp. 1 & 42 & 153 & & & & & $20 / 2$ \\
\hline Tectatodinium sp. 2 & 135 & 26 & 38 & 37 & & & $20 / 3-4$ \\
\hline Tectatodinium sp. 3 & 162 & 96 & 54 & 68 & & & $20 / 8-9$ \\
\hline Tectatodinium sp. 4 & 169 & 51 & & 6 & & & $20 / 6-7$ \\
\hline Thatassiphora deticata & & & & 96 & & & \\
\hline Thalassiphora fenestrata & 53 & 154 & & & & & $17 / 6$ \\
\hline Thalassiphora pelagica & 13 & 136 & & 97 & & & \\
\hline Tuberculodinium vancampoae & 98 & 52 & 32 & 38 & 45 & 15 & $20 / 11$ \\
\hline Trinovantedinium of. capitatum & 145 & 75 & & & 64 & 23 & $6 / 10$ \\
\hline Wetzeliella articulata & 14 & 173 & & 98 & 5 & 66 & $20 / 13$ \\
\hline
\end{tabular}

Other species: Areosphaeridium? actinocoronatum has its lowest appearance within this zone (above a low productivity interval). Areoligera sp. 1 is common near the top. Samlandia sp. 1 is restricted to the zone.

Comparison: The lowest appearance of Areosphaeridium? actinocoronatum marked the base of Manum's (1976) Zone III at Site 338 and Costa and Downie's (1979) Zone VI at the Rockall Plateau (DSDP Leg 48). Costa and Downie (1979) compared their Zone VI and Manum's (1976) Zone III with upper Rupelian-Chattian assemblages of North Germany (NP23/24 equivalent). The upper part of the present zone (above a sequence of low productivity) may be correlated with Zone III of Manum
(1976) and with Zone VI of Costa and Downie (1979), and represents upper lower to lower upper Oligocene.

\section{Impagidinium sp. 1 Zone (Sections 104-643A-46-5 to $-643 A-46-1)$, upper Oligocene}

Interval from lowest appearance of Impagidinium sp. 1 to lowest appearance of Systematophora sp. 1.

Other species: Distatodinium paradoxum, Homotryblium floripes, and Hystrichokolpoma rigaudiae appear simultaneously in similar numbers at the base of this zone. All three have a much earlier first appearance (Eocene) in other regions and so their late first appearance at this site is anomalous. (H. ri- 


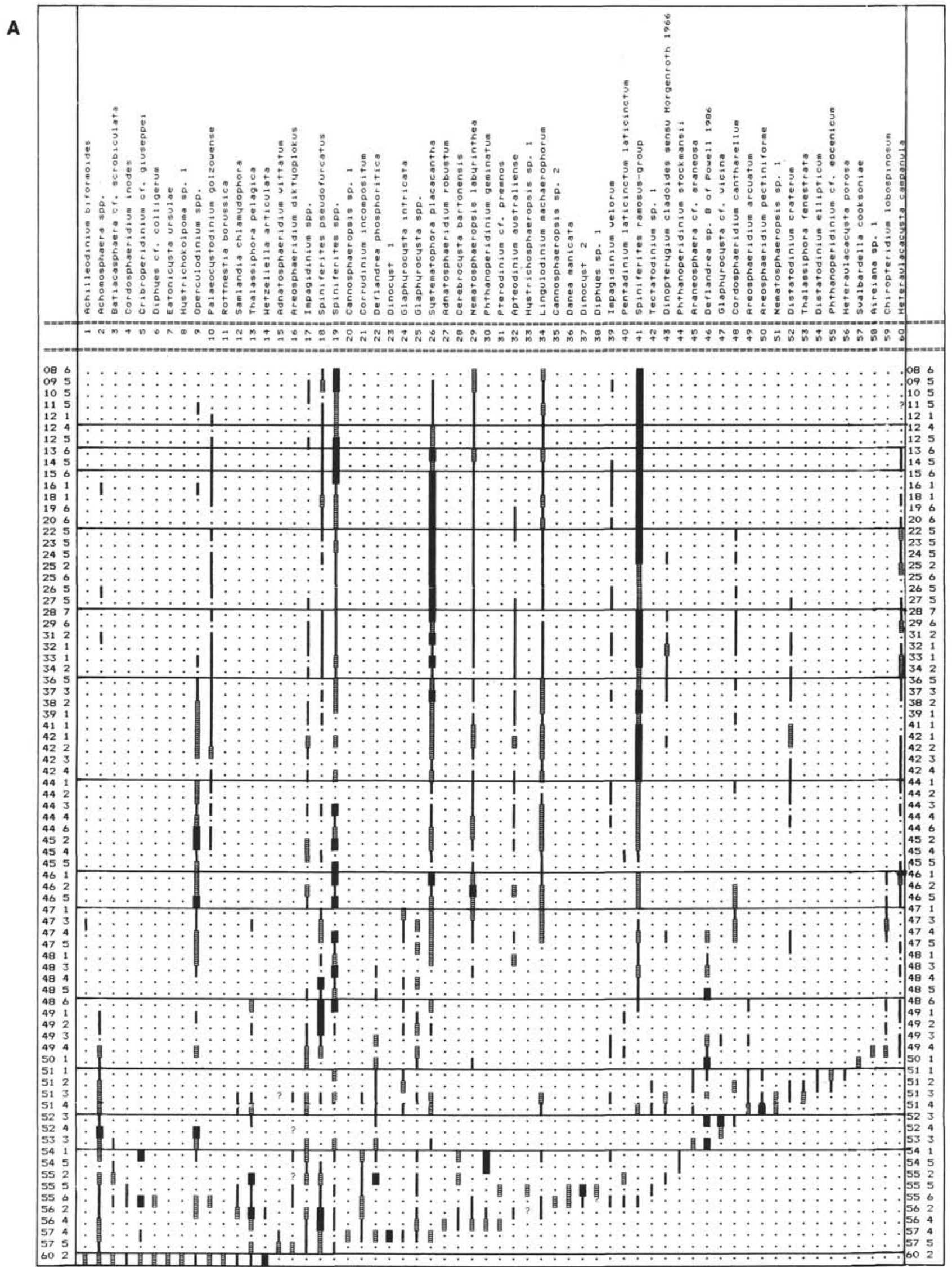

Figure 3. Range charts of dinocyst taxa at Site 643 arranged in the sequence of first (A) and last (B) appearances. Rare: $<2 \%$; Common: $2 \%-25 \%$; Abundant: $>25 \%$. 
A

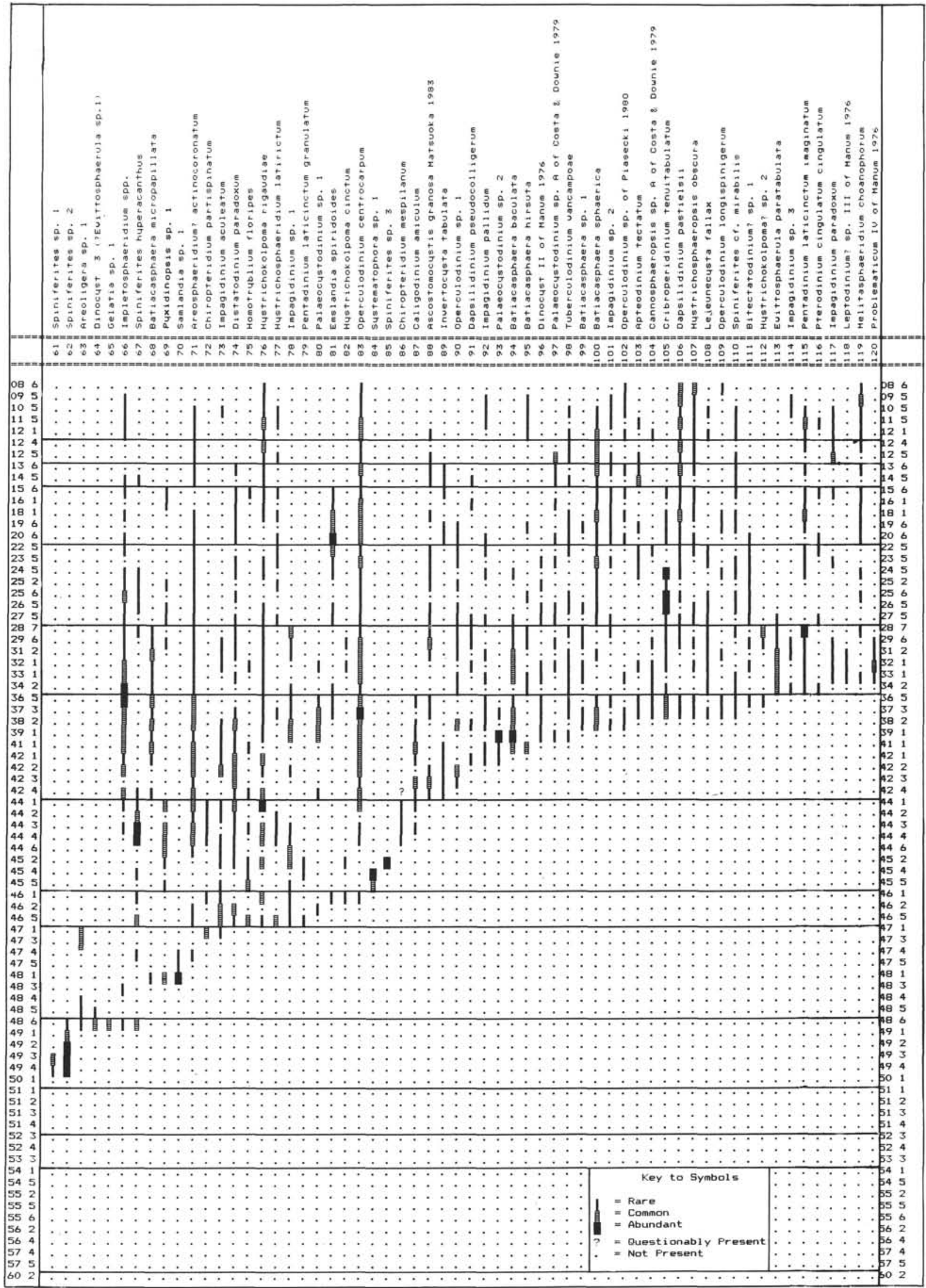

Figure 3 (continued). 


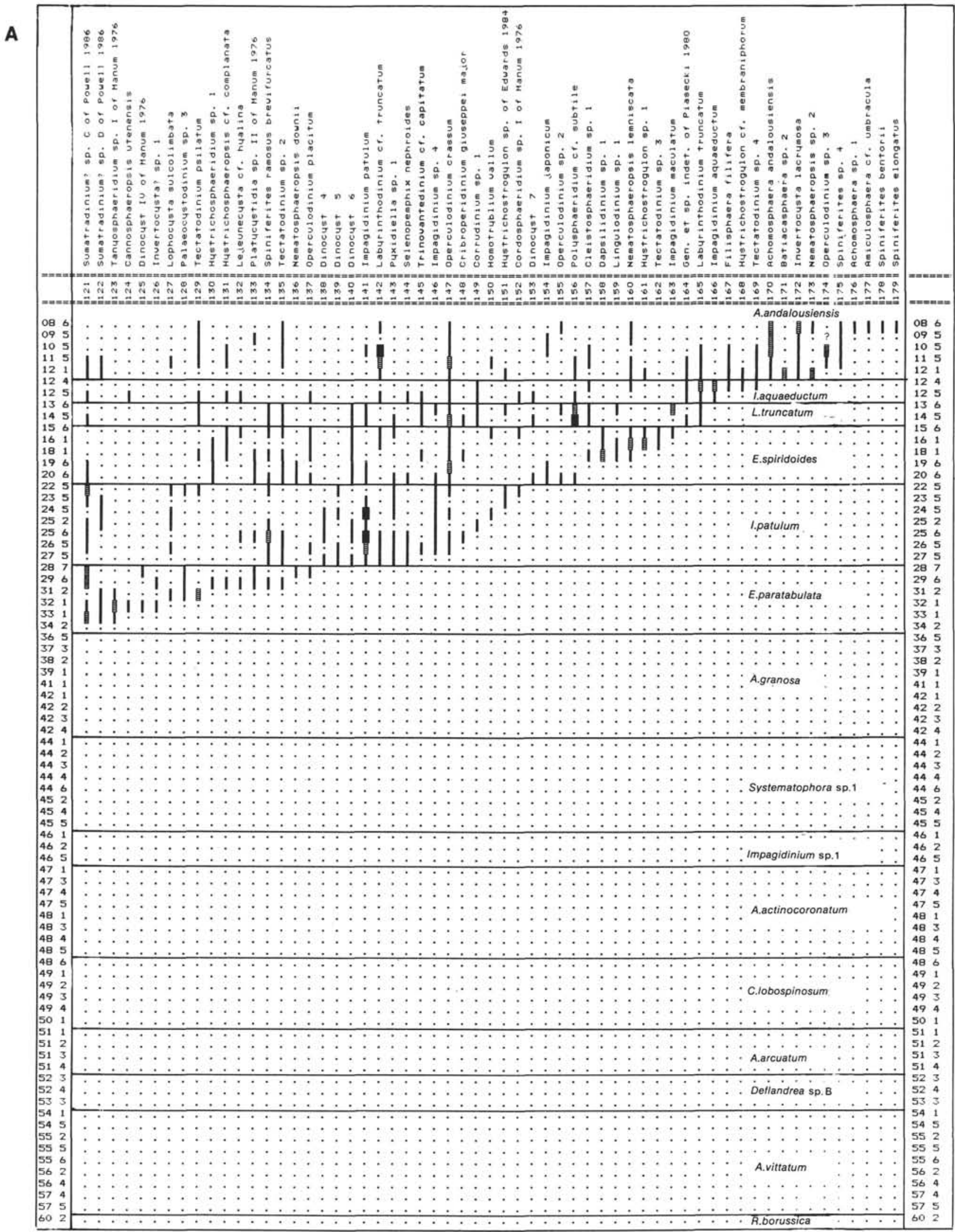

Figure 3 (continued). 


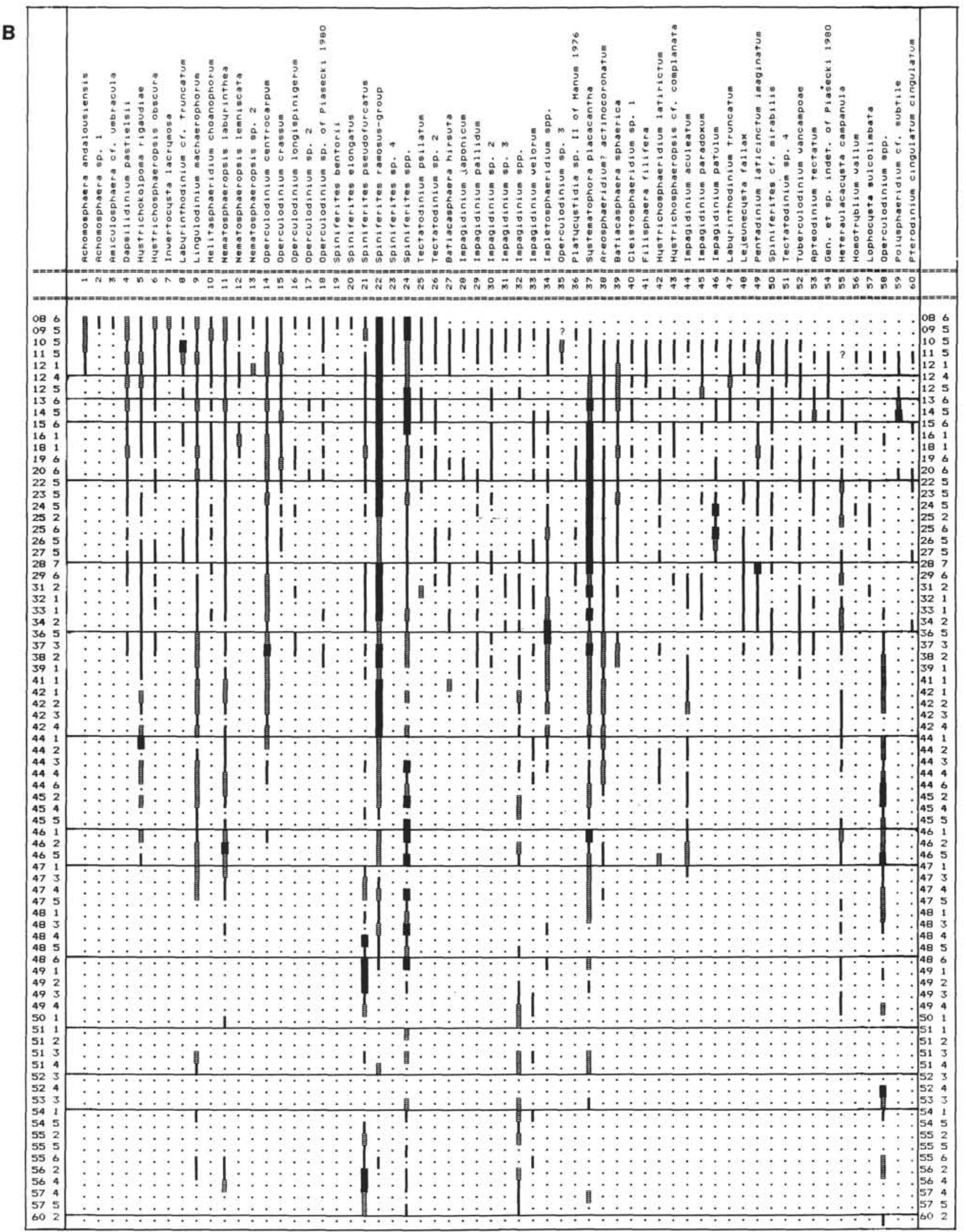

Figure 3 (continued). 
B

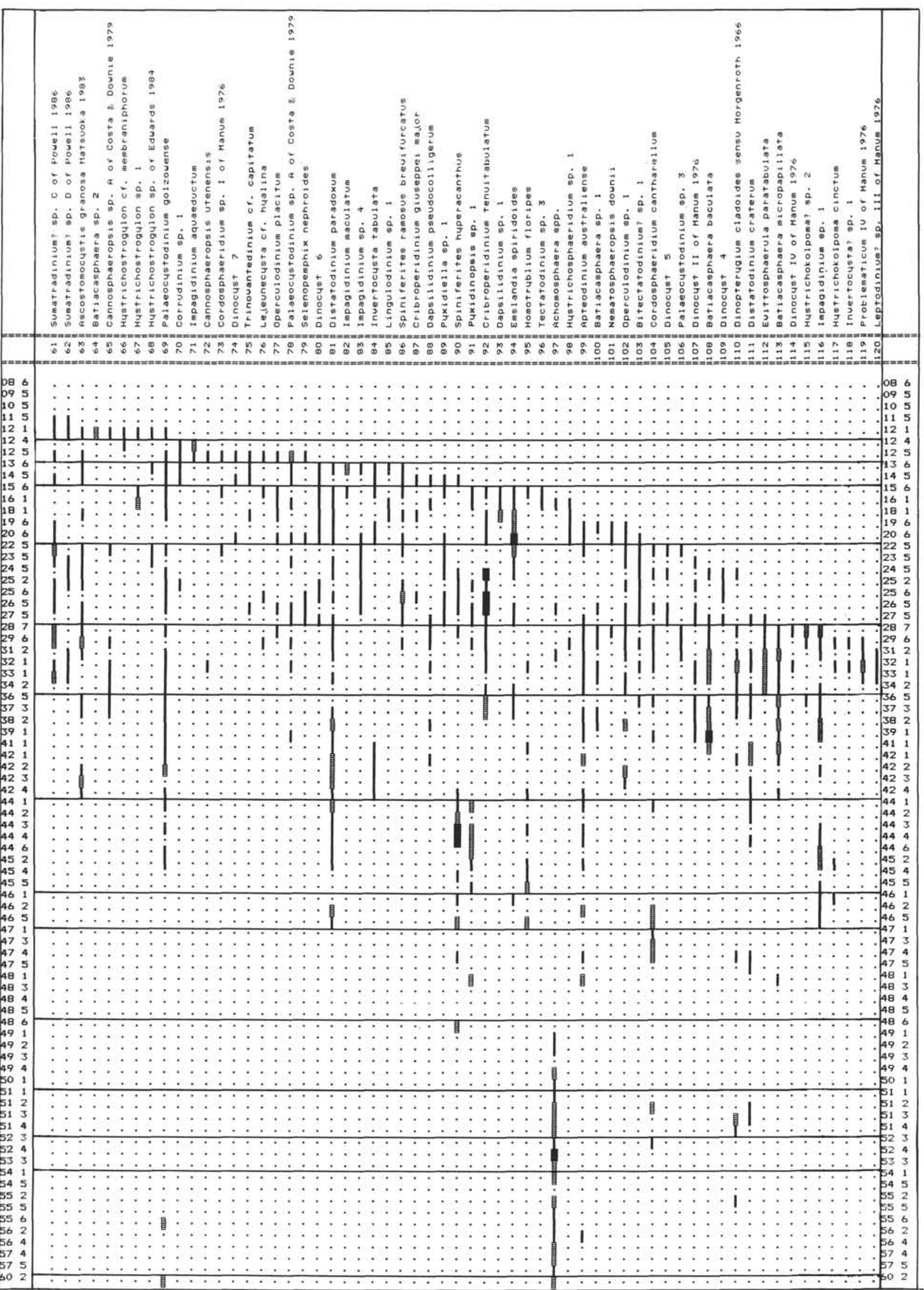

Figure 3 (continued). 


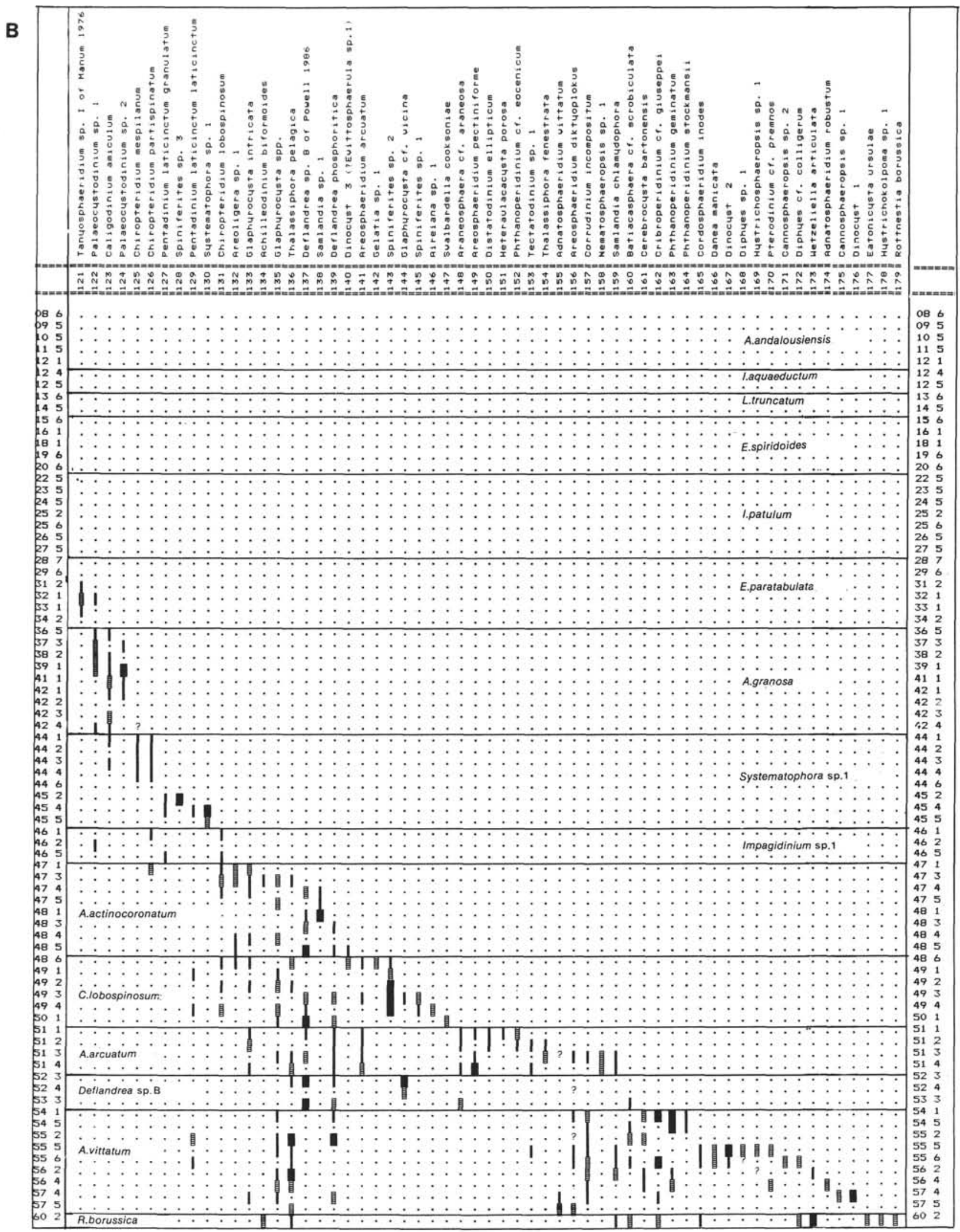

Figure 3 (continued). 
A

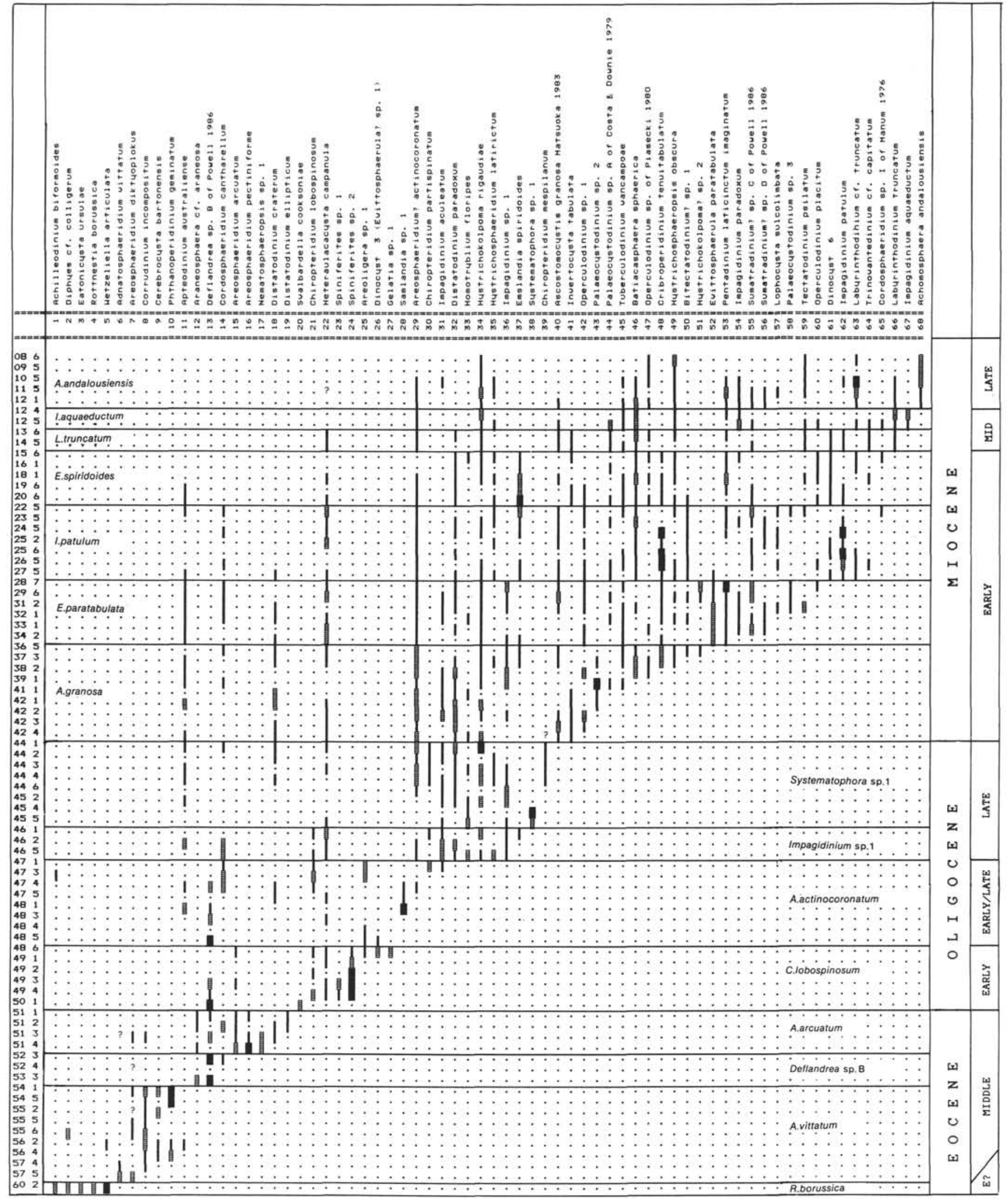

Figure 4. Range charts of the stratigraphically most significant taxa used for zonation at Site 643 arranged in the sequence of first (A) and last (B) appearances (key to symbols is in Fig. 3A). 
B

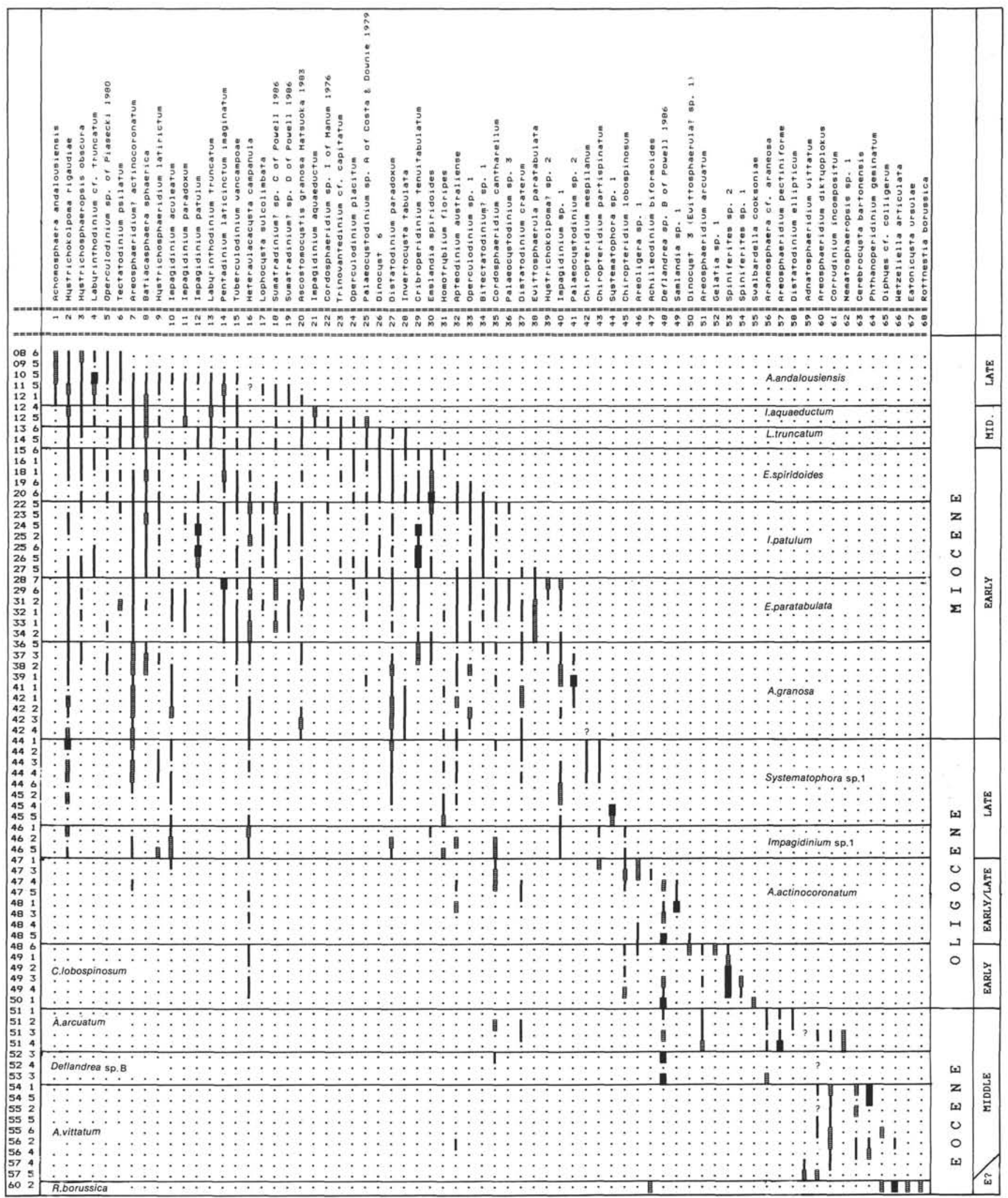

Figure 4 (continued). 
gaudiae has been recorded from around the Paleocene/Eocene boundary at Site $642 \mathrm{E}$; Boulter and Manum, this volume).

\section{Systematophora sp. 1 Zone (Sections 104-643A-45-5 to} -643A-44-1), upper Oligocene

Interval from lowest appearance of Systematophora sp. 1 to lowest appearance of Ascostomocystis granosa.

Other species: Hystrichokolpoma rigaudiae is common to abundant more or less throughout, Spiniferites hyperacanthus is abundant in the middle of the zone; Batiacasphaera sp. 1 is common in the upper part of the zone. Chiropteridium partispinatum has its highest appearance in this zone; $C$. mespilanum has its lowest appearance within this zone and ranges into the lowermost part of the zone above.

\section{Oligocene/Miocene Boundary}

The Oligocene/Miocene boundary is placed between the samples from Sections 104-643A-44-1 and -643A-42-4, marked by the highest appearance of Chiropteridium partispinatum (Section 104-643A-44-1) and the lowest appearance of Ascostomocystis granosa (Section 104-643A-42-4). (There was no sediment recovery from the intervening Core 104-643A-43). The pollen also shows a marked change at this point in the section, as discussed on page 22 .

Williams and Bujak (1985) indicate the stratigraphically highest appearance for $C$. partispinatum at the Oligocene/Miocene boundary; at Site 643 its highest appearance is in Section 104 643-44-1. In general, the highest appearance of the genus Chiropteridium is considered to be a reliable marker for the top of the Oligocene (Williams, 1975, 1977; Williams and Brideaux, 1975; Bujak, 1984). However, C. mespilanum ranges into the lowermost Miocene (NN1 equivalent: Williams and Bujak, 1985), Stover (1977), Ioakim (1979), and Powell (1986a) report Chiropteridium spp. from the earliest Miocene.

Ascostomocystis granosa is considered to be another boundary marker at Site 643. Williams and Bujak (1985) indicate lowest appearance of this species (alias $A$. sp. I) in the latest Oligocene (late NP25 equivalent). At Site 643, C. mespilanum (identified on a few fragments only) and Ascostomocystis granosa occur together in the sample from Section 104-643A-42-4. Therefore, following our discussion above, this sample cannot be assigned conclusively to either the Oligocene or the Miocene. Section 104-643A-38-2 has the lowest appearance of Batiacasphaera sphaerica, which is believed to be a Miocene indicator (Stover, 1977).

For Site 643 we have defined the Oligocene/Miocene boundary by the highest appearance of $C$. partispinatum, and the lowest appearance of $A$. granosa, i.e., between Sections 104-643A44-1 and $-643 \mathrm{~A}-42-4$.

\section{Miocene}

\section{Ascostomocystis granosa Zone (Sections 104-643A-42-4 to -643A-36-5), lower Miocene}

Interval from lowest appearance of Ascostomocystis granosa to lowest appearance of Evittosphaerula paratabulata.

Other species: lowest appearance at the base of the zone: Invertocysta tabulata. Lowest appearance close to the base of the zone: Operculodinium sp. 1. Lowest appearance within the zone: Batiacasphaera sphaerica, Cribroperidinium tenuitabulatum, Hystrichosphaeropsis obscura, Operculodinium sp., Palaeocystodinium sp. A, and Tuberculodinium vancampoae. Restricted to the zone: Palaeocystodinium sp. 2.

Comparison: $A$. granosa occurs from the base of Zone IIa of Manum (1976; alias $A$. sp. I), indicating a correspondence to this zone; however, it is uncertain to what extent they overlap. Costa and Downie's (1979) Zone VIIa from the Rockall Plateau, and Powell's (1986b) Subzone LAN-1-A from the Piedmont Basin, both stated to be latest Oligocene, share a few first appearances with this zone, viz. $T$. vancampoae (Rockall and Piedmont), Palaeocystodinium sp. A, and Invertocysta tabulata (Rockall only; both in Piedmont from middle Miocene). However, A. granosa was not recorded in either of the two areas. Stover (1977) reported the lowest appearance of $B$. sphaerica and $T$. vancampoae in his lower Miocene Tuberculodinium interval from the eastern United States; his assemblage compares well with ours.

\section{Evittosphaerula paratabulata Zone (Sections 104-643A-34-2 to -643A-28-7), lower Miocene}

Interval from lowest appearance of Evittosphaerula paratabulata to lowest appearance of Impagidinium patulum.

Other species: lowest appearance at the base of the zone: Pentadinium laticinctum imaginatum. Lowest appearance within the zone: Impagidinium paradoxum, Lophocysta sulcolimbata, Palaeocystodinium sp. 3, Sumatradinium? sp. C and S.? sp. D, and Tectatodinium psilatum. Highest appearance at the top of the zone: Impagidinium sp. 1 and Hystrichokolpoma? sp. 2. Restricted to the zone: Invertocysta? sp. 1, Leptodinium? sp. III, Problematicum IV, Tanyosphaeridium sp. I.

Comparison: E. paratabulata is common to abundant in lower Miocene sediments from DSDP Sites 338, 342, 345, 346, and 348 (Manum, 1979); however, it also occurs in an upper Oligocene sample from Site 338 (Core 23) and in unconfirmed Oligocene from Site 348 (Core 30). Pentadinium laticintum imaginatum (alias $P$. cf. taeniagerum) and Problematicum IV have their first appearances at the base of Manum's (1976) Zone IIa from the lower Miocene of Site 338, indicating that Zone IIa overlaps the lower part of the present zone; the lower part of Manum's Zone Ic appears to overlap the upper part of this zone.

In the Piedmont Basin, Powell (1986b) recorded the lowest appearance of his Sumatradinium? sp. C in Subzone LAN-1-B, and the highest appearance of Distatodinium craterum at the top of the same zone. These two lowest and highest appearances compare with the present zone $(D$. craterum ranges just into our next zone); however, LAN-1-B is stated to be upper Oligocene. In Rockall, the highest appearance of $D$. craterum is in the lower Miocene, within Zone VIIb of Costa and Downie (1979).

\section{Impagidinium patulum Zone (Sections 104-643A-27-5 to -643A-22-5), lower Miocene}

Interval from lowest appearance of Impagidinium patulum to highest appearance of Cordosphaeridium cantharellum.

Other species: lowest appearance at the base of the zone: Dinocyst 6 and Labyrinthodinium 6, cf. truncatum. Lowest appearance within the zone: Impagidinium sp. 4. Highest appearance within the zone: Batiacasphaera baculata and Dinopterygium cladoides. Restricted to the zone: Dinocyst 4 and 5 .

Comparison: Assemblages containing I. patulum were recorded by Costa and Downie (1979) from the middle Miocene of the Rockall Plateau, but otherwise their assemblages show little similarity to ours. From the Bay of Biscay, Brown and Downie (1985) recorded lower Miocene assemblages (in NN2NN4 strata) which can be compared to the present zone. Their lowest record of I. patulum was from NN2 strata, where it is associated with Areosphaeridium? actinocoronatum (alias Impletosphaeridium sp. I), Cannosphaeropsis sp. A, Distatodinium paradoxum, Emslandia spiridoides and Hystrichosphaeropsis obscura. 
In the Piedmont Basin, Powell (1986b) recorded I. patulum from the middle Miocene (LAN-5-B), and $I$. cf. patulum from the lower Miocene (LAN-3-B). From the illustration of the latter we consider Powell's (1.c.) morphotype to be within the range of variability acceptable for $I$. patulum, whose stratigraphic range would thus begin in the lower Miocene in Piedmont.

Williams (1977) recognized a Cordosphaeridium cantharellum Zone from the lower Miocene in the Grand Banks which appears to compare with the present $A$. granosa to $I$. patulum zones. Both $C$. cantharellum and $D$. cladoides disappear in the C. cantharellum Zone as well as in the I. patulum Zone.

\section{Emslandia spiridoides Zone (Sections 104-643A-20-6 to -643A-15-6), lower Miocene}

Interval from highest appearance of $C$. cantharellum to lowest appearance of Labyrinthodinium truncatum.

Other species: highest appearance at the top of the zone: Emslandia spiridoides and Cribroperidinium tenuitabulatum. Highest appearance within the zone: Apteodinium australiense, Bitectatodinium? sp. 1 and Operculodinium sp. 1. Restricted to the zone: Hystrichostrogylon sp. 1.

Comparison: We agree with Williams and Bujak (1985) that Apteodinium sp. B of Williams and Brideaux (1975) is synonymous with $E$. spiridoides. As defined by Williams and Bujak (1985) for offshore eastern Canada, the $A$. sp. B Zone spans the interval from the highest appearance of Chiropteridium mespilanum to the highest appearance of $A$. sp. B ( $=E$. spiridoides), thus starting much earlier than the present $E$. spiridoides Zone. The tops of the Canadian and the present zone are defined by the disappearance of the same species, yet there is a difference which makes the correlation of tops uncertain: highest appearance of $C$. cantharellum is at the base of the present zone, whereas in sediments offshore Canada it coincides with the top of E. spiridoides. Williams and Bujak (1985) indicate highest appearance of $A$. spiridoides at the top of the lower Miocene. However, based on the biostratigraphic synthesis of all data from Leg 104 (Goll, this volume), our A. spiridoides Zone may range into the middle Miocene. The upper part of Manum's (1976) Zone Ic compares well to this and the preceeding zones, particularly with regard to the highest appearances of $C$. cantharellum, D. cladoides, and E. spiridoides.

\section{Labyrinthodinium truncatum Zone (Sections 104-643A-14-5 to -643A-13-6), middle Miocene}

Interval from lowest appearance of Labyrinthodinium truncatum to lowest appearance of Impagidinium aquaeductum.

Other species: lowest appearance at the base of the zone: Corrudinium sp. 1 and "Gen. et sp. indet." Highest appearance at the top of the zone: Distatodinium paradoxum.

Comparison: The present zone is recognized on the basis of the same species as those used by Piasecki (1980) for the $L$. truncatum Zone he erected for the Danish Miocene. In the Danish material as well as the present, first appearances and ranges of "Gen. et sp. indet." and L. truncatum coincide. Similarly, there is also a disappearance of $D$. paradoxum at the top of this zone. The lowest appearances of Apteodinium tectatum and Spiniferites mirabilis were noted within this zone in Denmark, but at Site 643 they appear earlier, in the Ascostomocystis granosa Zone; however, Piasecki (1980) had no lower Miocene material, which may explain this difference. In the Rockall Plateau, L. truncatum and "Gen. et sp. indet." are restricted to the middle Miocene (NN7/8 strata; Edwards, 1984). Although their lowest appearance seems to correspond to Site 643 , we have ob- served their disappearance in younger sediments than at Rockall. Manum (1976) reported L. truncatum (alias Cordosphaeridium sp. II) from Zone Ia in the middle Miocene. In addition, Edwards (1986) reported L. truncatum from middle Miocene sediments in South Carolina.

The middle Miocene age for the species characteristic of this zone appears to be well documented (Manum, 1976; Edwards, 1984: nannofossils; Piasecki, 1980: molluscs). The lower/middle Miocene boundary is therefore defined at the base of this zone. However, data from other biostratigraphers of Leg 104 (Goll, this volume) indicate that this zone boundary may be placed somewhat up into the middle Miocene.

\section{Impagidinium aquaeductum Zone (Sections 104-643A-12-5 to -643A-12-4), middle Miocene}

Interval from lowest appearance of Impagidinium aquaeductum to lowest appearance of Achomosphaera andalousiensis.

Other species: highest appearance within the zone: Cordosphaeridium sp. I, Trinovantedinium $\mathrm{cf}$. capitatum, Operculodinium placitum, and Palaeocystodinium sp. A.

Comparison: The present zone is recognized on the same basis as the I. aquaeductum Zone of Piasecki (1980) defined for the Danish Hodde Formation (middle Miocene). Systematophora placacantha and Spiniferites pseudofurcatus have their highest appearance at the top of this zone in the Hodde Fm., whereas at Site 643 they range into the zone above.

Manum (1976) recorded I. aquaeductum (as Leptodinium sp. V) from his Zone Ia (middle Miocene), which compares well with our L. truncatum and I. aquaeductum zones. Edwards (1984) and Brown and Downie (1985) reported the lowest appearance of $I$. aquaeductum in the middle Miocene of Rockall and the Bay of Biscay respectively; Brown and Downie (1985) reported $I$. aquaeductum also from the upper Miocene. In the Piedmont Basin, Powell (1986b) recognized an I. aquaeductum Zone (LAN-6) from the Serravallian (middle Miocene), but with a quite different cyst association.

\section{Achomosphaera andalousiensis Zone (Sections from 104-643A-12-1), upper Miocene}

Interval from lowest appearance of Achomosphaera andalousiensis; the top of this zone cannot be defined (highest sample, Section 104-643A-8-6; compare Mudie (this volume) for higher samples and overlap with ours).

Other species: highest appearance within the zone: Areosphaeridium? actinocoronatum, Ascostomocystis granosa, Batiacasphaera sphaerica, Hystrichosphaeridium latirictum, Labyrinthodinium truncatum, Palaeocystodinium golzowense, Pentadinium laticinctum imaginatum, Sumatradinium? sp. C and S.? sp. D. Restricted to the zone: Achomosphaera sp. 1, Nematosphaeropsis sp. 2.

Comparison: The A. andalousiensis Zone Piasecki (1980) defined for the Danish Gram Formation (upper Miocene, stratigraphic control: molluscs; planktonic foraminifer Zone N15N16) is recognized on the basis of the lowest appearance of $A$. andalousiensis, as well as corresponding highest appearances of $P$. laticinctum, $P$. golzowense, and "Gen. et sp. indet." Data from Site 643 agrees closely with Piasecki (1980). In the Bay of Biscay area, A. andalousiensis has its lowest appearance in the upper Miocene (Harland, 1979; Brown and Downie, 1985: NN11 strata. However, the latter authors have a hiatus from NN7 to NN10). In the Piedmont Basin, Powell (1986b) identified the $A$. andalousiensis Zone (LAN-8) with an association that may be compared to the present showing the following highest appearances within the zone: $P$. golzowense, $H$. latirictum (alias? Cor- 
dosphaeridium? minimum) and Dapsilidinium pastielsii. Powell (l.c.) indicated a late middle Miocene age for this zone in the Piedmont Basin (planktonic foraminifer Zone N12). However, upper Miocene highest appearances were reported in Piedmont for $P$. laticinctum and Sumatradinium? sp. C, both with highest appearances in the $A$. andalousiensis zone at Site 643. Benedek (1980) reported $A$. andalousiensis from presumed middle Miocene strata of the Netherlands. Harland (1978) placed the lowest appearance of $A$. andalousiensis at the middle/upper Miocene boundary. Offshore eastern Canada, Williams (1977) and Williams and Bujak (1977) defined a P. laticinctum Zone that may be compared to the $L$. truncatum Zone and the lower part of the $A$. andalousiensis Zone herein; species characteristic of the $P$. laticinctum Zone $(P$. laticinctum, $H$. obscura, and $P$. golzowense) range into the $A$. andalousiensis Zone at Site 643.

The base of this zone is used here to define the boundary between the middle and upper Miocene in our material. For this, we rely mainly on the stratigraphic control by Piasecki (1980) for his Danish material. Data from other relevant areas also support this age determination (Harland, 1978 and 1979; Brown and Downie, 1985). However, A. andalousiensis has also been reported from middle Miocene sediments in the Piedmont Basin (Powell, 1986b) and from the Netherlands (Benedek, 1980). These occurrences may well represent range differences which are enviromentally controlled, particularly the Mediterranean one for which there also appears to be good stratigraphic control.

\section{CORRELATION OF DINOCYSTS BETWEEN SITES 642 AND 643}

\section{Hole 642D (Figs. 5A and 5B, Table 3)}

Sections 104-642D-14-2 to -642D-13-3 contain an early Eocene assemblage based on the presence of Deflandrea oebisfeldensis and Apectodinium quinquelatum, which is older than the lowest zone at Site 643 (Rottnestia borussica Zone). A. quinquelatum, Cerebrocysta bartonensis, Eatonicysta ursulae, and Diphyes colligerum were also reported from lower Eocene sediments at the Goban Spur (Brown and Downie, 1985).

Sections 104-642D-13-1 to -642D-8-6 contain completely different assemblages which are of distinctly Miocene composition.* Smalley et al. (this volume) have reported isotope ages for carbonate (microfossils) and phosphate (fish teeth) from core 104-642D-12, Sections 4 and 5, which yielded dates of $38.0 \pm$ 1.5 $\mathrm{Ma}$ and $37.0 \pm 1.0 \mathrm{Ma}$, respectively, equating a late Eocene age. They argue that the consistency of their isotope ages makes reworking unlikely, and that the palynomorphs, therefore, must be contaminants from higher levels in the borehole. Against this we argue that the stratigraphic distribution of the dinocyst taxa shown in Table 3 presents a coherent and convincing story, strongly indicating in-situ conditions. We therefore think that the radiometrically dated fossils are reworked. Some support for this conclusion is also to be found in the core descriptions for Core 104-642D-12 (Eldholm, Thiede, Taylor, et al., 1987, page $354)$, where reworked sand is stated to be among the major lithologies. In Section 104-642D-13-2 there is a change in lithology just below our undiagnostic sample from Section 104-642D13-2. Our sample below this lithologic change, from Section

\footnotetext{
- In his biostratigraphic synthesis of Leg 104 Goll (this volume) argues that drilling disturbances from younger strata have produced mixing of younger fossils in 104-642D-13-1 through 642D-11. Consequently he concludes that this section is of Eocene age. We now favor this conclusion.
}

104-642D-13-3, is the highest sample with an Eocene assemblage. There is a distinct assemblage change between Sections 104-642D-13-3 and 642D-13-1, marking the boundary between the Eocene and the Miocene. Our samples from Sections 104642D-13-2, -642D-12-6, and -642D-11-2 have few diagnostic cysts, but the others have good assemblages diagnostic of the Miocene. Eocene forms are missing. The assemblage from Section 104-642D-13-1 belongs to the E. paratabulata zone, those from the interval 104-642D-12-6 to -642D-5-6 belongs to the $I$. patulum Zone. The assemblage from Section 104-642D-3-2 belongs to the $E$. spiridoides Zone. The sample from Section 104642D-2-6 contains a poor and undiagnostic assemblage, which could not positively be correlated to either the $E$. spiridoides or the $L$. truncatum Zone. Between the Sections 104-642D-3-2 and $-642 \mathrm{D}-2-6$ there is another assemblage change, suggesting a hiatus (Fig. 6; we have not studied any material from Core 104642D-1).

\section{Hole 642C (Figs. 5A and 6)}

Our highest sample from Hole 642D (from Section 104-642D2-6) and the lowest from Hole 642C (from Section 104-642C24-3) lack the zone diagnostic species $E$. spiridoides and $L$. truncatum. It is therefore difficult to correlate between them and with Site 643. However, the presence of Batiacasphaera sp. 1 and Operculodinium sp. 1 in Section 104-642C-24-3, which have their highest appearance in the $E$. spiridoides Zone at Site 643, suggests a correlation for Section 104-642C-24-3 to that zone. This sample contains Dinocyst II and Palaeocystodinium golzowense in abundance, which is not observed from Site 643; furthermore, there is an increase in species diversity from Section 104-642C-24-3 to -642C-23-2. These differences between Sites 642 and 643 suggest the presence of a sequence at Site 642 that is missing at Site 643 , occupying a position between the $E$. spiridoides and $L$. truncatum Zones. The interval 104-642C-232 to $-642 C-21-6$ correlates with the $L$. truncatum Zone, and the interval from Section 104-642C-20-7 to $-642 C-17-1$ correlates with the I. aquaeductum zone. I. aquaeductum is of rare to common occurrence throughout the zone at Site 643. At Site $642 \mathrm{C}$, however, I. aquaeductum is recorded only at the base of the zone.

The interval from Sections 104-642C-19-3 to -642 C-17-1 contains species not observed at Site 643 (Litosphaeridium sp. 1 and Operculodinium cf. giganteum), suggesting that this interval at Site 642 represents a sequence that is missing from Site 643 between the $I$. aquaeductum and $A$. andalousiensis Zones (Fig. 5A).

The interval $104-642 \mathrm{C}-15-1$ to $-642 \mathrm{C}-12-1$ contains $A$. andalousiensis, associated also are species which were not recorded from Site 643, viz. Achomosphaera ramulifera, Bitectatodinium tepikiense, and Evittosphaerula? sp. 2. The association of B. tepikiense with $A$. andalousiensis in the upper part of the latter's range has been observed also in the Bay of Biscay (Brown and Downie, 1985) and the central North Atlantic (Mudie, 1986). Since this association was not observed at Site 643 , we conclude that Sections 104-642C-15-1 and higher are younger than our highest sample from Site 643 (Fig. 6). Section 104-642C-10-1 is considered to be of Pliocene age. Hystrichosphaeropsis obscura, the highest appearance of which is believed to be a good Miocene-Pliocene marker (Drugg and Stover, 1975; Williams and Bujak, 1985) has its highest appearance in our sample from Section 104-642C-12-1. The presence of Filisphaera filifera in Section 104-642C-10-1 suggests a Pliocene age for this interval (Bujak, 1984). We do not propose any zonation for the Pliocene (see Mudie, this volume). 
A

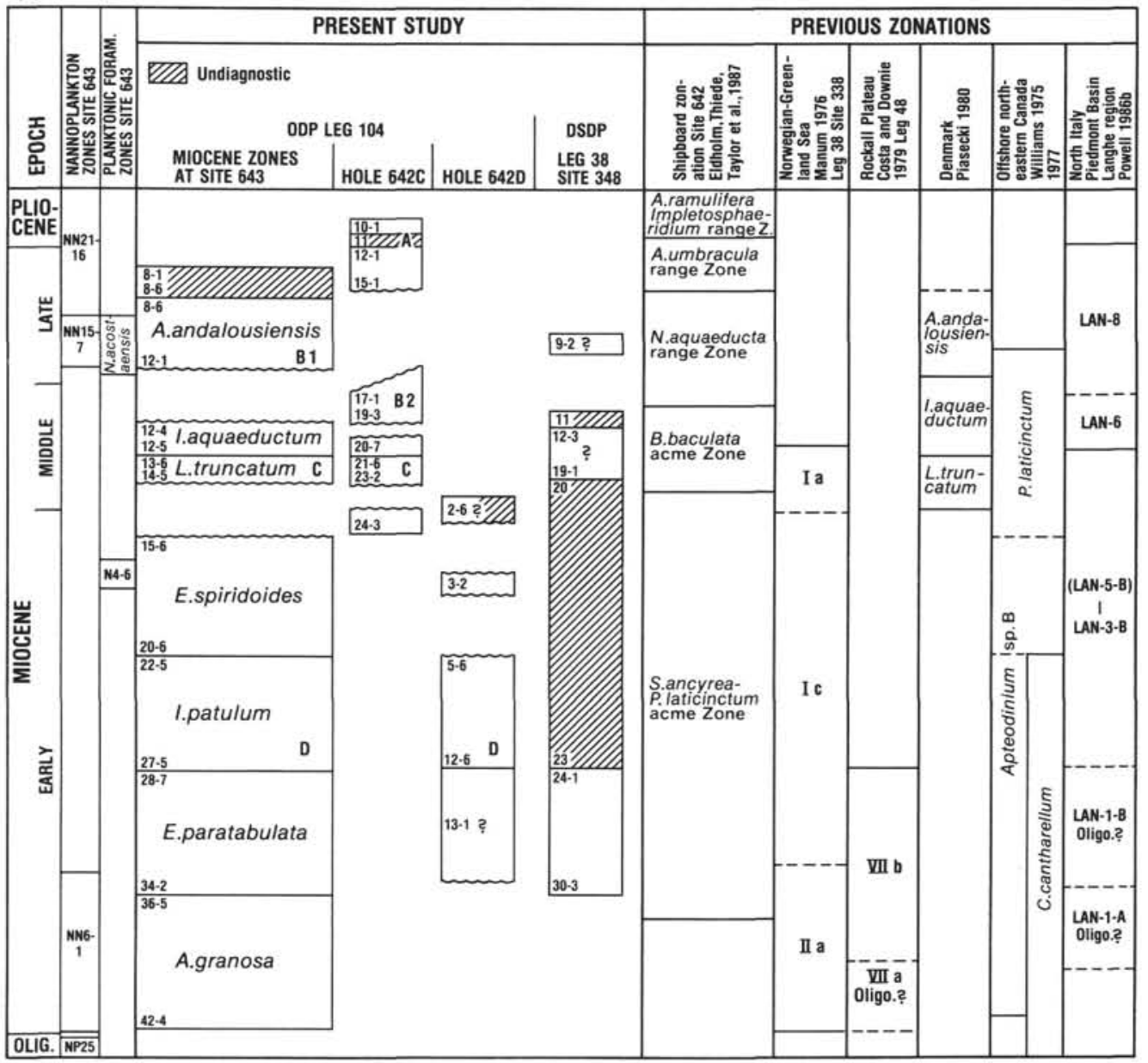

B

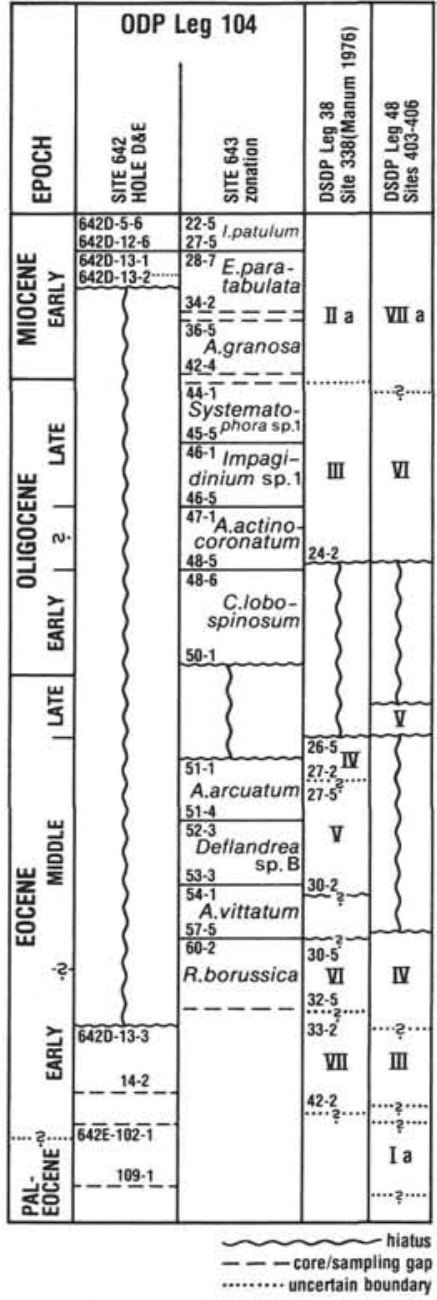

Figure 5. A. Proposed correlation of the Miocene dinocyst zonation for Leg 104, Sites 643, 642C/D, with Legs 38 and 48 , Denmark, offshore Northeast Canada, and the northern Italy Piedmont Basin. The palynomorph maxima A-D shown in Figures 2 and 7 are indicated in the respective zones for Sites 642 and 643. B. Proposed dinocyst correlation of Paleogene sections, Leg 104, with those of DSDP Legs 38 and 48.

The absolute palynomorph frequency maximum B (Fig. 7) appears in the lower upper Miocene at Site 643 (indicated by B1), but appears in the upper middle Miocene at Site 642, Holes B and C (indicated by B2 in Fig. 2). This differentiation of the maximum B is based on our zonal correlation between Sites 643 and 642 as discussed above and shown in Figure 5A.

\section{INTERPRETATION OF THE POLLEN AND SPORE DATA}

Besides being relatively uncommon in most of the samples we have studied, the pollen and spores are far less useful for zonation and correlation. In most of the samples pollen and spores are absent, or else are represented by a few specimens of bisaccate pollen which have been transported long distances by wind and water. The results of our semiquantitative analysis are presented in Figures 8 and 9. The lowest sample we have examined from Site 643 is Section 104-643A-60-2, $32 \mathrm{~cm}$. It contains abundant remains of Azolla massulae with glochidia (Plate 21), suggesting that warm freshwater conditions were close to the area of deposition. Identical fossils have been recorded from DSDP Leg 38 Site 338, at $300 \mathrm{~m}$ (Boulter, 1986) and from Site 343 at $148 \mathrm{~m}$ (middle Eocene). We do not suggest that a correlation between the two holes can be based on just one sample from each.
One very clear trend within these data is the difference between the Paleogene and Neogene assemblages. The Paleogene samples from Site 643 are dominated by conifer pollen, many of which are of types absent in the Neogene. A particularly noticeable form is what we call BIGFRILLED MONOSACCATES (Plate 21), in which the frill is up to $20 \mu \mathrm{m}$ wide. Paleogene forms of triporate pollen are also present only in these samples.

Pollen is more or less absent in samples close to the Eocene/ Oligocene boundary, but that from adjacent samples can contribute to the debate on the position of this boundary. Figure 8 shows that BIGFRILLED MONOSACCATES have their highest appearance at Section 104-643A-42-4, $20 \mathrm{~cm}$, in the same sample that contains common VERRUCATE MONOCOLPATES. This is just below a part of the section which is more or less lacking terrestrially derived fossils. Paleogene bisaccates have their highest appearance in the sample below, Section 104$643 \mathrm{~A}-44-3,30 \mathrm{~cm}$. Our dinocyst data cause us to place the Oligocene/Miocene boundary between our Sections 104-643A-42-4 and -643A-44-1. Although there is no useful pollen assemblage in this latter sample, it is clear that another feature of the boundary is the highest appearance of BIGFRILLED MONOSACCATES.

The considerable changes in the pollen and spore assemblages at this part of Site 643 (Fig. 8) have not been detected so 
Table 3. Dinocyst ranges in Sections 104-642D-8-6 through -14-2. Carbonate and phosphate fossils radiometrically dated from the upper Eocene were sampled from Sections 104-642D-12-4 and -5 (Smalley et al., this volume).

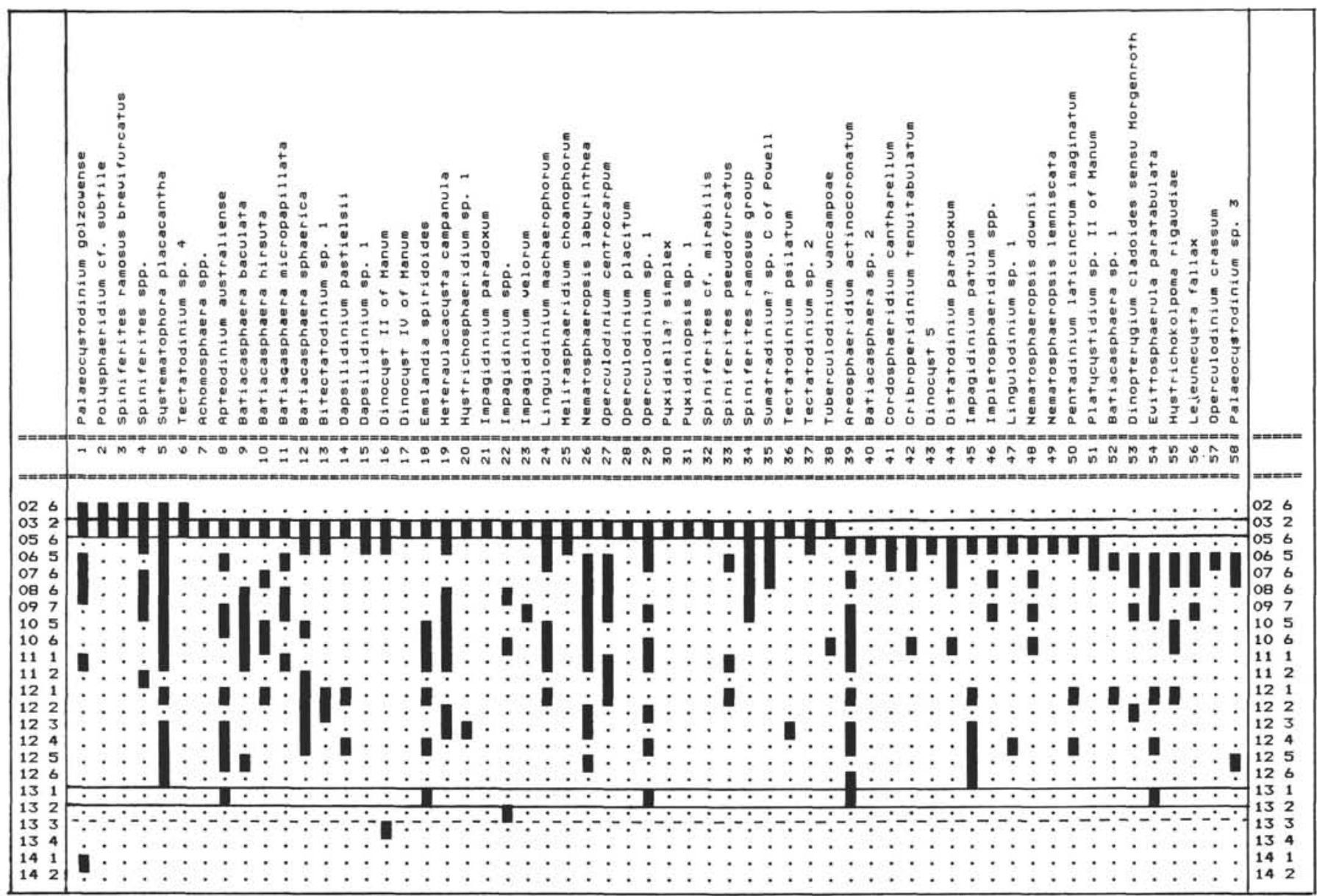

clearly before in sections of this age. The palynomorphs are from a similar marine facies and there are enough productive samples to make a reliable comparison between Paleogene and Neogene pollen and spore assemblages. The results show clearly that the Neogene assemblage is consistent and different from the Paleogene one (which is also consistent taxonomically). There are at least three explanations for this difference: (a) The change is due to major alterations in ocean currents causing palynomorphs from a different source to be deposited at Site 643. The consistency of both the Neogene and Paleogene assemblages means that largely the same taxa were present in each region for more than 10 m.y. before and after the change. (b) The change is due to an event that stimulated a surge in the rate of evolution of some of the land plants. (c) The change is due to plant migration caused by alterations in the environment.

The Miocene samples from Sites 643 and 642 show very little variation in their pollen assemblages. We can expect a wellmixed and allochthonous range of terrigenous fossils in marine sediments such as these, but the continuity of the pollen suggests that there was very little change in the source vegetation throughout the Miocene. This observation is in line with DSDP Leg 38 work by Koreneva et al. (1976), who identified one palynoflora (NK3) during the Miocene, and with Leg 104 shipboard observations (Eldholm, Thiede, Taylor, et al., 1987). The lack of change may be due to the selective influences of marine deposition or else may partly represent a truly static vegetation at the source of these sediments for the greater part of the Miocene.

\section{INTERPRETATION OF THE ABSOLUTE PALYNOLOGICAL COUNTS}

Significant qualitative and quantitative changes in the Eocene-to-Miocene palynomorph assemblages of the Norwegian Sea were observed by Manum (1976). These changes undoubtedly reflect much of the changing depositional enviroments such as land-sea relationships and oceanic circulation patterns which developed during the post-Paleocene tectonic evolution of the North Atlantic. However, the evolution and distribution of organisms were also affected. Manum (1976) presented only relative palynomorph data to illustrate some of the major changes. For the present study, absolute quantitative control of the palynomorph concentrations in the sediments have been obtained, with the objective of gaining improved insight into the events reflected by these newly recognised changes.

Three variables: fossil pollen and spores, dinoflagellates, and the Lycopodium spores added in controlled quantities, were counted in at least one sample from each pre-Pliocene core, and the total quantity of palynomorphs present in one gram of sediment were calculated. Absolute palynomorph frequencies for Site 643 (Fig. 7) show some striking variations, and it is possible to correlate maxima and minima between Sites 643 and 642 
Table 3 (continued).

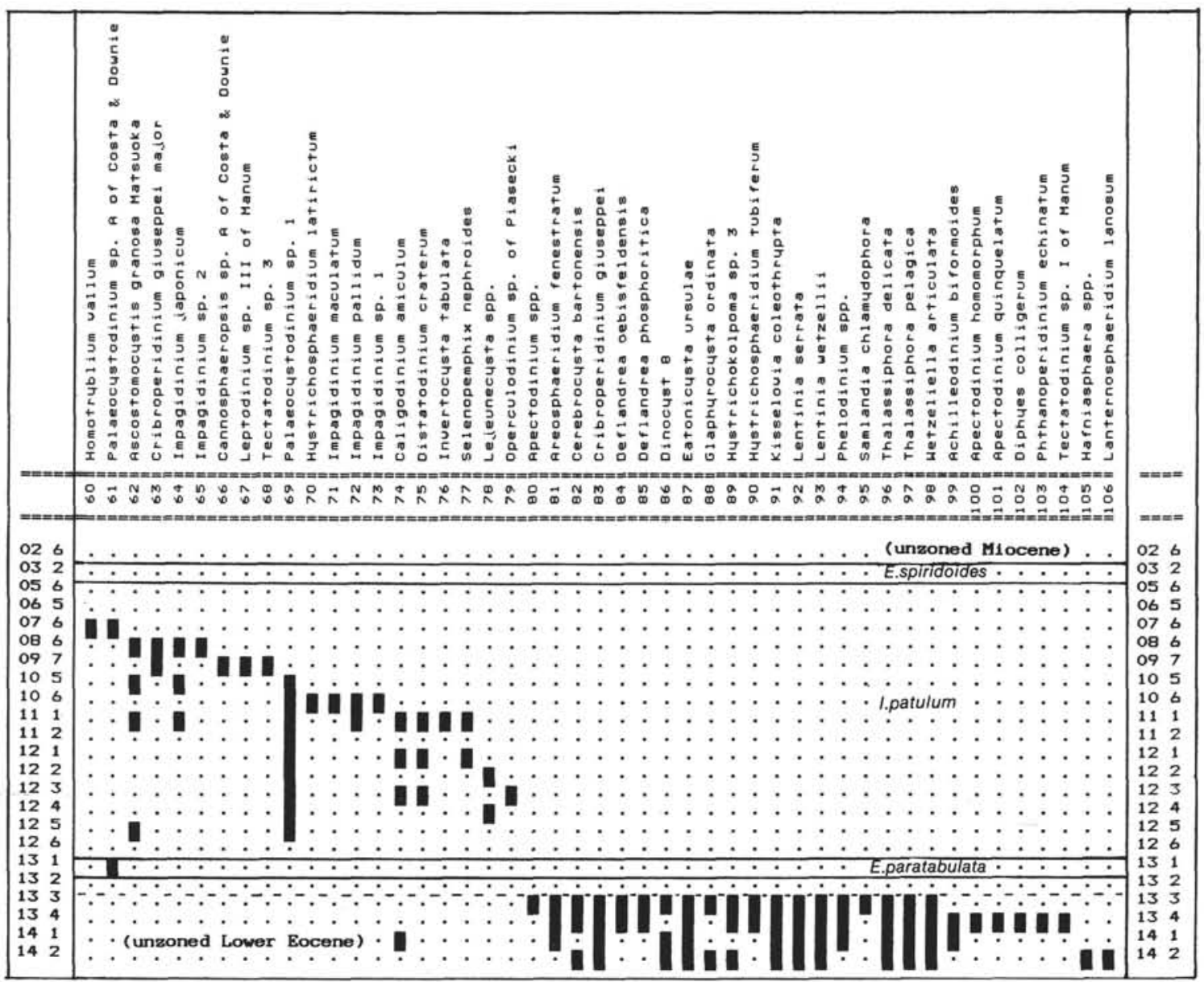

(Figs. 2, 5A and 7). The most prominent change occurs between 380 and 350 mbsf (Cores 104-643-41 to -643-37). During this interval, the average amounts increase from a level of the order of $10,000-20,000$ palynomorphs to the order of $100,000-150,000$ in $1 \mathrm{~g}$ of sediment. The cyst stratigraphy and shipboard nannoplankton studies (Eldholm, Thiede, Taylor, et al., 1987) indicate that the age of this event is earliest Miocene.

Another noteworthy feature is the frequent large fluctuations between maxima and minima, more or less throughout the entire sequence, and a drop to about half the average palynomorph contents at about $\mathbf{2 0 0}$ mbsf in the upper lower Miocene. The increase in palynomorph contents noted at $380-350 \mathrm{mbsf}$ is mainly due to higher frequencies of dinocysts. Dinocyst frequencies in the Paleogene range from less than 1.000 to rarely exceeding 30,000 , while from the lowermost Miocene frequencies are generally between 50,000 and 100,000 in $1 \mathrm{~g}$ of sediment, with a conspicuous maximum just below $350 \mathrm{~m}$ (Fig. 7). We believe that this shift to higher cyst frequencies is related to increased cyst recruitment rather than to changes in sediment input. There is no corresponding lithological shift at this level (Eldholm, Thiede, Taylor, et al., 1987). In fact, the lithology shift from Unit V to Unit IV appears earlier and is not expressed in our data (Fig. 7).

Our view that the lowermost Miocene event reflects a change in cyst recruitment rather than in the sediment dilution factor is also supported by preliminary estimates of sedimentation rates. A conservative figure for the thickness of the middle Eocene section is $90 \mathrm{~m}$. As indicated by our distinct cyst zones, there are breaks in this section, as well as truncations below and above. If about half the middle Eocene is thought to be missing, the average sedimentation rate is $15 \mathrm{~mm}$ per m.y. An estimate for the $250 \mathrm{~m}$ of lower Miocene section above the event (interval from $380 \mathrm{mbsf}$ to $130 \mathrm{mbsf}$ ) leads to an average sedimentation rate of $36 \mathrm{~mm}$ per $1 \mathrm{~m} . \mathrm{y}$. This rate is based on the assumption, for which there is biostratigraphical support, that there is no major break in this section except in the upper part (see Figure 5A). Sedimentation rates therefore appear to be considerably higher after, than before, this event. The dilution effect on marine palynomorphs is thus higher after the event, but is more than compensated by higher cyst recruitment.

The Paleogene section shows low pollen frequencies and there is hardly any terrestrially derived palynodebris, quite unlike the situation in lower to middle Eocene sections at DSDP Leg 38 Sites 338 and 343 (Manum, 1976; Talwani, Udintsev, et al., 1976; Boulter and Riddick, 1986). The Paleogene section at Site 643 has several large gaps which make further interpretation of our data difficult. The terrestrial vs. marine palynomorph ratios (Fig. 10) show large variations, particularly in the middle Eocene, which suggest changing conditions. The early lower Miocene event takes place over a little less than 1 m.y., estimated from the Miocene sedimentation rates proposed above. This appears to be too early to be related to the submergence of the Iceland-Faeroe Ridge, which substantially changed the oceanic circulation in the Norwegian Sea. The fluctuations observed in the 


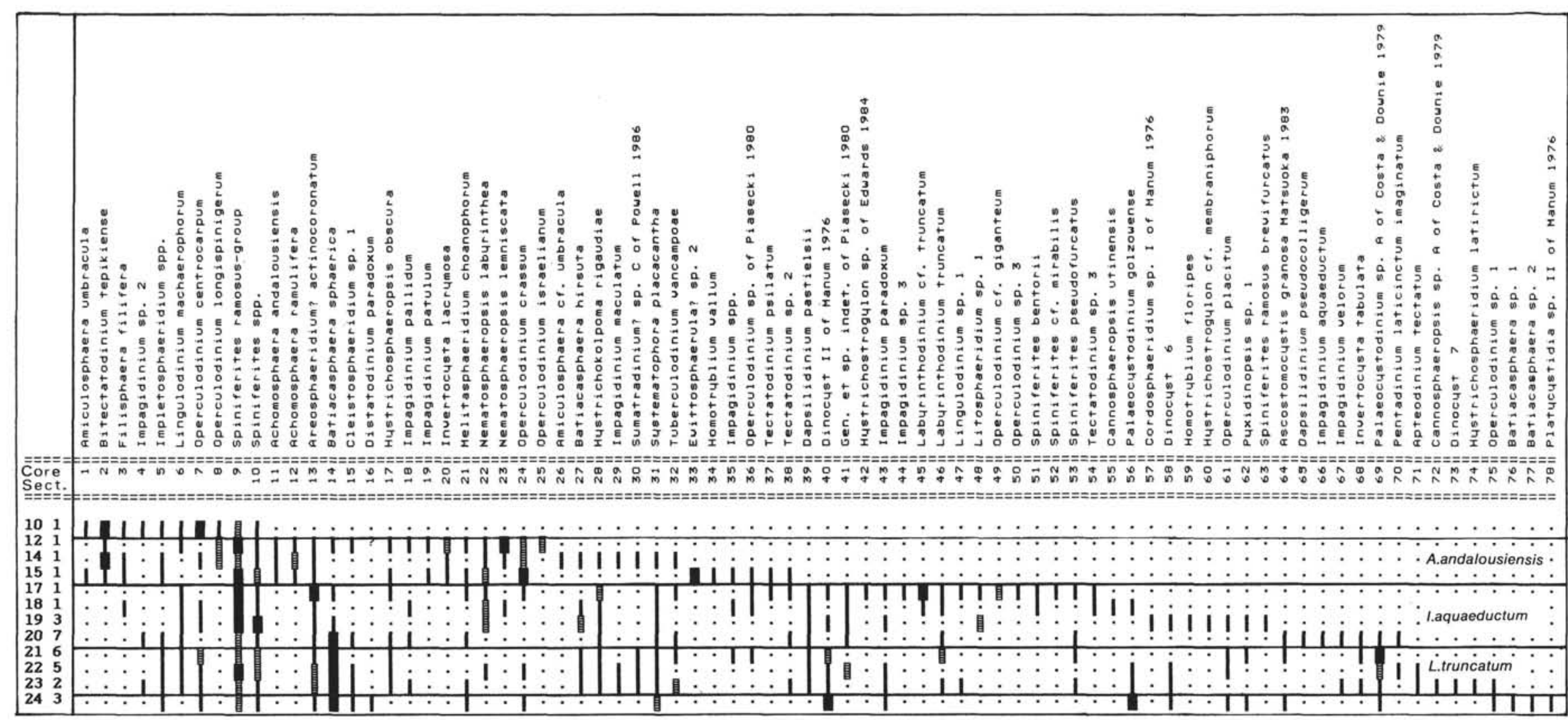

Figure 6. Range chart of dinocyst taxa arranged in the sequence of first appearance at Hole $642 \mathrm{C}$ (key to symbols is in Fig. 3A). 


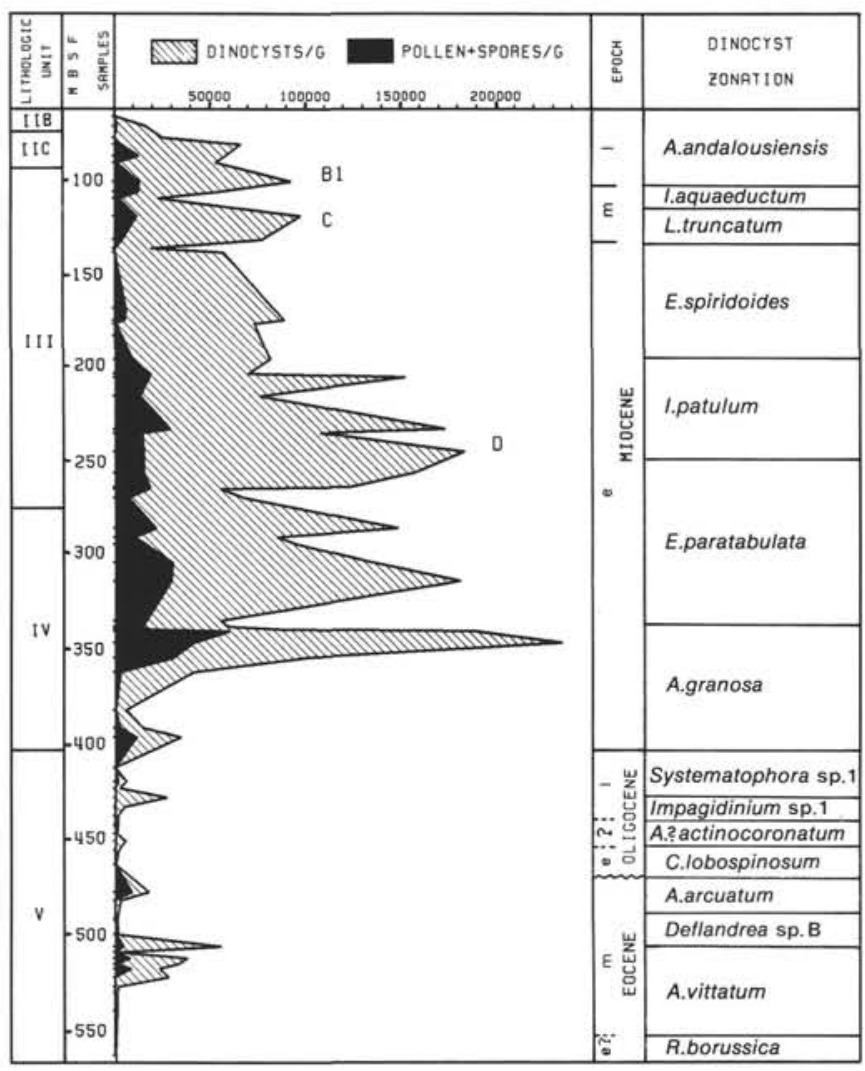

Figure 7. Graphical presentation of absolute frequency counts of marine and terrestrial palynomorphs for Site 643 . The palynological maxima B-D correlate with results from Site 642 in Figure 2.

Miocene section may have been controlled by ecological factors which have affected cyst input. Opal data (Henrich et al., this volume) suggests changes in planktonic productivity which appear to support this interpretation.

\section{COMPARISONS TO DSDP LEG 38}

Correlation with Norwegian Sea sites from DSDP Leg 38 are difficult because of differences between the dinocyst assemblages from the various sites. These differences may in part be explained by environmental variations. However, results from Leg 104 have confirmed the impression from Leg 38 that nowhere is there a continuous Tertiary sequence that offers a complete micropaleontological record. Major hiatuses evidently occur at different stratigraphical positions at different sites (Fig. 6), and this is obviously creating correlation problems. Dinocyst correlations which can be made with Leg 38, and Site 338 in particular, are discussed above under the individual zones. Correlations to Site 348 and to Manum's (1976) zonation for Site 338 are presented in Figure 5A.

The Oligocene and Miocene palyno-events shown for Site 338 in the Vøring Plateau and other Leg 38 sites (Manum, 1976), also appear at Site 643. In Figure 10, absolute palynomorph counts for Site 643 are presented as relative frequencies to compare with those for Site 338. Compared to the Site 338 data, there appears, possibly, to be less consistency and more "noise" in the data from Site 643; also, Site 643 shows less dramatic change in relative frequencies in the Eocene than Site 338 . However, the lower Eocene section showing low relative cyst frequencies at Site 338 is missing at Site 643, and the middle Eocene was represented by only two samples on the steep upward-trending part of the curve for Site 338. Both Site 338 and Site 643 curves show a downward trend in the late Oligocene, an upward trend in the early Miocene, and again a downward dinocyst frequency trend in the middle Miocene. The latest Paleogene and early Neogene records for Site 643 therefore show similarity to those from Site 338.

\section{CONCLUSION}

Palynomorphs are present in useful amounts in nearly all cores of the Eocene to Miocene sections studied from ODP Sites 642 and 643 . While pollen and spores are of limited biostratigraphic value, dinoflagellate cysts can be used throughout for zonation and correlation; however, key species for existing zonations are generally scarce or lacking. A local zonation scheme was established based on the sequence from Site 643 . Still, sufficient age diagnostic species are present that allow identification of epochs. The dinocysts thus become particularly important in the Paleogene sections where other biostratigraphic indicators are missing (Eldholm, Thiede, Taylor, et al., 1987: 144, 483).

The number of previously undescribed taxa recorded is high, even for the taxonomically better-known Paleogene. The environments prevailing in the Norwegian Sea were clearly different from areas of previous taxonomic studies, as indicated by the different species composition and ranges. Detailed paleoenvironmental interpretations and their effect on dinocyst distribution, however, were not possible within the scope of this paper. Of the 15 local dinocyst assemblage zones distinguished at Site 643 , the top three zones, representing middle and upper Miocene, were recognized previously in Denmark; the remainder were defined from the Leg 104 material alone, but are to varying degrees correlatable with previous DSDP zonations from the northern Atlantic (Legs 38, 48, and 81) and from the Piedmont Basin in northern Italy (Miocene).

At Site 643, dinocysts indicate a middle Eocene age from Cores 104-643A-51 to -643A-57. The lower Eocene has not been confidently identified, although one sample from Section 104$643 \mathrm{~A}-60-2$ is possibly of the lower Eocene. Otherwise, Cores 104-643A-58 to $-643 \mathrm{~A}-62$ (bottom of the hole) are either barren or with undiagnostic assemblages. No upper Eocene section has been identified, indicating a middle Eocene to lower Oligocene hiatus somewhere in the section between our samples from Sections 104-642A-50-1 and -642A-51-1. The Oligocene section contains upper Oligocene assemblages from Sections 104-643A-46-5 to $-643 \mathrm{~A}-44-1$ and lower Oligocene assemblages from Sections $104-643 \mathrm{~A}-50-1$ to $-643 \mathrm{~A}-48-6$. The intervening cores represent a dinocyst zone that is not diagnostic of either lower or upper Oligocene.

The Oligocene/Miocene boundary is placed between Sections 104-643A-42-4 and -643A-44-1, which has few dinocysts but abundant pollen which show a major change at this part of the section.

Miocene dinocyst ages at Site 643 conform to those based on other microfossil groups, lower Miocene assemblages being identified in Sections 104-643A-15-6 to -643A-42-4, middle Miocene in Sections 104-643A-12-4 to -643A-14-5, and upper Miocene from Sections 104-643A-8-6 to -643A-12-1; our sample from $-643 \mathrm{~A}-8-1$ yielded an undiagnostic Miocene-Pliocene assemblage.

At Site 642, the Paleogene section above the basalts is represented only by the lower Eocene (Sections 104-642D-13-3 to $-642 \mathrm{D}-14-2)$. The lower Miocene is identified from Core 642D10 , thus indicating a lower Eocene-lower Miocene hiatus at Site 642.

Dinocyst assemblage changes in the middle Miocene in Hole 642D suggest hiatuses between Sections 104-642D-2-6 and -642D3-2, and between -642D-3-2 and -642D-5-6. An upper middle Miocene sequence appears to be represented in Hole $642 \mathrm{C}$ but is missing at Site 643 (Fig. 5A). 

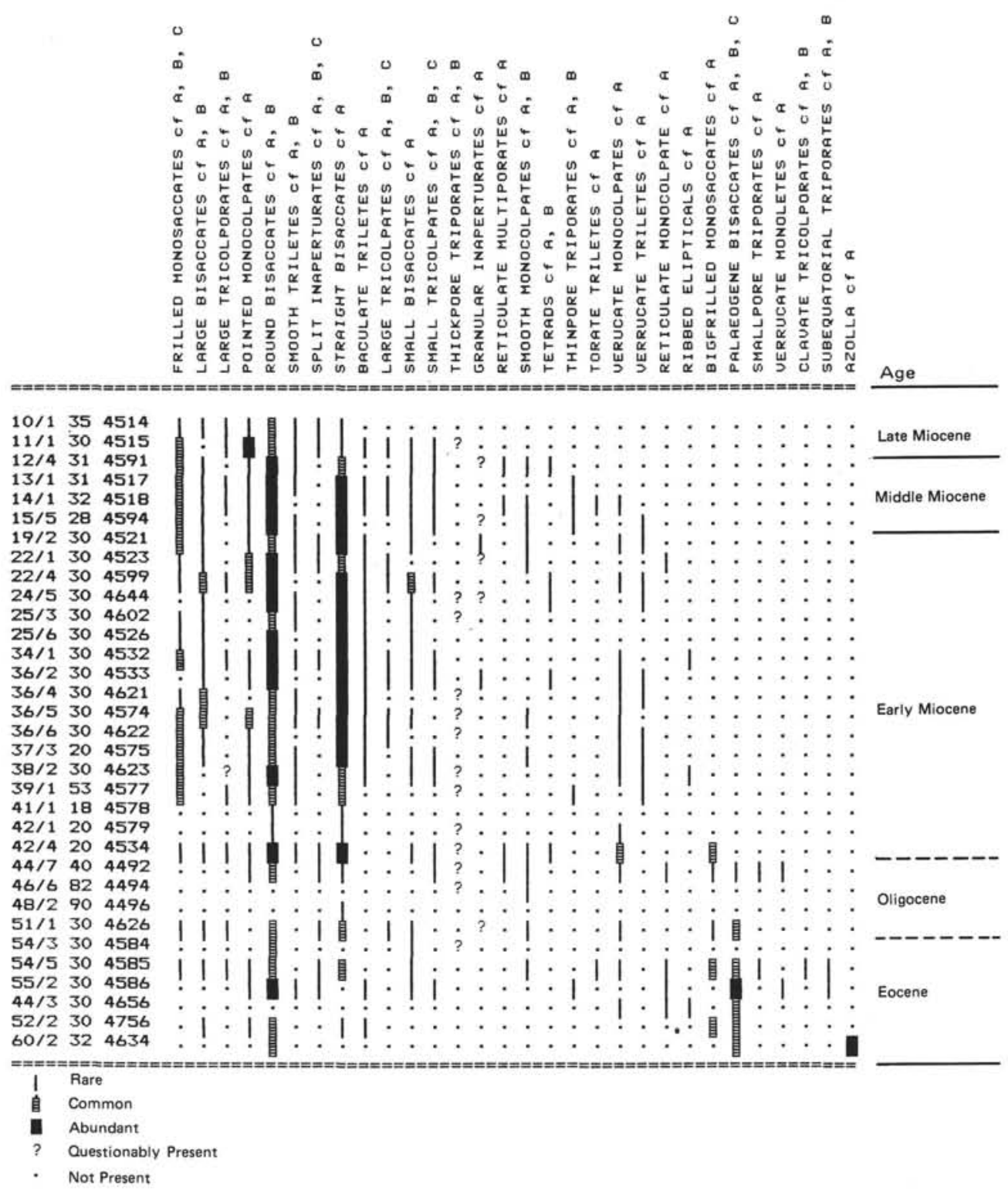

Figure 8. Range chart of pollen and spore types at Site 643 arranged in the sequence of last appearance.

In the lowermost Miocene sediments at Site 643, absolute dinocyst frequencies increase substantially over a relatively short interval and remain at a higher level than in the Paleogene. Because sedimentation rate considerations make it unlikely that the observed change is related to a change in the sediment dilution effect, the most likely explanation is an ecological event.

\section{ACKNOWLEDGMENTS}

We thank the shipboard scientists on ODP Leg 104 for sampling the cores, Astri Dugan and Berhanu Kifle (University of Oslo) for making the palynological preparations, and P. Mudie (Atlantic Geoscience Center, Dartmouth) for useful discussions. R. Henrich (Kiel University) kindly provided TOC data for comparisons. This study forms the major part of a research project initiated by the two senior authors: "Tertiary Geohistory of the northern Atlantic realm, as elucidated by palynological methods"; a VISTA-project financed by Statoil, Norway, under the auspices of the Norwegian Academy of Science and Letters. Knut Bakken (Statoil, Stavanger) helped communications with Statoil.

\section{REFERENCES}

Benedek, P. N., 1980. Vorläufige Ergebnisse der Phytoplankton-Untersuchungen aus dem nordwesteuropäischen Tertiärbecken. IGCP Project 124, The northwest European Tertiary Basin, Rept., 6:87-92.

Boulter, M. C., 1986. Pollen and spore events from the marine Tertiary of north Europe. J. Micropalaeontol., 5:75-84.

Boulter, M. C., and Riddick, A., 1986. Classification and analysis of palynodebris from the Palaeocene sediments of the Forties Field. Sedimentology, 33:871-886.

Brosius, M., 1963. Plankton aus dem nordhessischen Kasseler Meeressand (Oberoligozän). Z. deutsch. Geol. Ges., 114:32-56.

Brown, S., 1986. Nematosphaeropsis downii sp. nov.: a new dinoflagellate cyst from Miocene sediments in the Bay of Biscay. J. Micropalaeontol., 5:7-10.

Brown, S., and Downie, C., 1985. Dinoflagellate cyst stratigraphy of Paleocene to Miocene sediments from the Goban Spur (Sites 548550, Leg 80). In Graciansky, P. C. de, and Poag, C. W., et al., Init. Repts. DSDP, 80: Washington (U. S. Govt. Printing Office), 643651. 
Bujak, J. P., 1984. Cenozoic dinoflagellate cysts and acritarchs from the Bering Sea and northern North Pacific, D.S.D.P. Leg 19. Micropaleontology, 30:180-212.

Bujak, J. P., Downie, G., Eaton, G. L., and Williams, G. L., 1980. Dinoflagellate cysts and acritarchs from the Eocene of southern England. Spec. Pap. Palaeontol., 24:1-100.

Costa, L. I., and Downie, C., 1976. The distribution of the dinoflagellate Wetzeliella in the Palaeogene of north-western Europe. Palaeontology, 19:591-614.

1979. Cenozoic dinocyst stratigraphy of sites 403 to 406 (Rockall Plateau), IPOD, Leg 48. In Montadert, L., and Roberts, D. G., Init. Repts. DSDP, 48: Washington (U. S. Govt. Printing Office), 513-529.

Drugg, W. S., and Stover, L. E., 1975. Stratigraphic range charts-selected Cenozoic dinoflagellates. Am. Assoc. Stratigr. Palynol., Contr. Ser., 4:73-77.

Eaton, G. L., 1976. Dinoflagellate cysts from the Bracklesham Beds (Eocene) of the Isle of Wight, southern England. Bull. Br. Mus. (Nat. Hist.), Geol., 26:227-332.

Elde, T., 1985. The late Eocene dinoflagellate flora at DSDP Site 338 (Vøring Plateau) [unpublished thesis], University of Oslo, Norway.

Eldholm, O., Thiede, J., Taylor, E., et al., 1987. Proc. ODP, Init. Repts., 104: College Station, TX (Ocean Drilling Program).

Edwards, L. E., 1984. Miocene dinocysts from Deep Sea Drilling Project Leg 81, Rockall Plateau, eastern North Atlantic Ocean. In Roberts, D. G., Schnitker, D., et al., Init. Repts. DSDP, 81: Washington (U.S. Govt. Printing Office), 581-594.

1986. Late Cenozoic dinoflagellate cysts from South Carolina, U.S.A. Am. Assoc. Stratigr. Palynol., Contr. Ser., 17:45-57.

Haaland, T., 1981. A palynological study of Eocene-Oligocene sediments on the Jan Mayen Ridge (DSDP Site 346). [unpublished thesis], University of Oslo, Norway.

Harland, R., 1978. Quaternary and Neogene dinoflagellate cysts. In Thusu, B., (Ed.), Distribution of biostratigraphically diagnostic dinoflagellate cysts and miospores from the northwest European continental shelf and adjacent areas. Institut for kontinentalsokkelundersøkelser (IKU), Publ. 100:7-17.

1979. Dinoflagellate biostratigraphy of Neogene and Quarternary sediments at holes 400/400A in the Bay of Biscay (Deep Sea Drilling Project Leg 48). In Montadert, L., Roberts, D. G., Init. Repts. DSDP, 48: Washington (U.S. Govt. Printing Office), 531545.

Ioakim, K., 1979. Étude comparative des dinoflagellés du Tertiaire inférieur de la Mer du Labrador et de la Mer du Nord [Thèse diplome de docteur], troisième cycle a l'Universite Pierre et Marie Curie (Paris IV): $1-204$.

Johnsen, K., 1983. Palynological study of Tertiary sediments on the Iceland-Faeroe Ridge (DSDP Site 336). [unpublished thesis], University of Oslo, Norway.

Koreneva, E. V., Zaklinskaya, E. D., Bratseva, G. M., and Kartashova, G. G., 1976. Palynology studies of sites $336,338,345,346$, and 348, DSDP Leg 38. In Talwani, M., Udinitsev, G., et al., Init. Repts. DSDP, 38: Washington (U.S. Govt. Printing Office), 1169-1194.
Lentin, J. K., and Williams, G. L., 1985. Fossil dinoflagellates: index to genera and species. Can. Tech. Rep. Hydrogr. Ocean. Sci., 60.

Matsuoka, K., 1983. Late Cenozoic dinoflagellates and acritarchs in the Niigata District, Central Japan. Palaeontographica B, 187:89-154.

Manum, S. B., 1976. Dinocysts in Tertiary Norwegian-Greenland Sea sediments (Deep Sea Drilling Project Leg 38) with observations on palynomorphs and palynodebris in relation to environment. In Talwani, M., Udintsev, G., et al., Init. Repts. DSDP, 38: Washington (U.S. Govt. Printing Office), 897-919.

, 1979. Two new Tertiary dinocyst genera from the Norwegian Sea: Lophocysta and Evittosphaerula. Rev. Palaeobot. Palynol., 28: 237-248, pl. 1-2.

Morgenroth, P., 1966. Mikrofossilien und Konkretionen des Nordwesteuropäischen Untereozäns. Palaeontographica B, 119:1-53.

Mudie, P. J., 1986. Palynology and dinoflagellate biostratigraphy of Deep Sea Drilling Project Leg 94, Sites 607 and 611, North Atlantic Ocean. In Ruddiman, W. F., Thomas, E., et al., Init. Repts. DSDP, 94: Washington (U.S. Govt. Printing Office), 785-812.

Piasecki, S., 1980. Dinoflagellate cyst stratigraphy of the Miocene Hodde and Gram Formations, Denmark. Bull. Geol. Soc. Denmark, 29: 53-76.

Piasecki, S., 1980. Dinoflagellate cyst stratigraphy of the Miocene Hodde and Gram Formations, Denmark. Bull. Geol. Soc. Denmark, 29:5376.

1986b. A dinoflagellate cyst biozonation for the late Oligocene to middle Miocene succession of the Langhe region, northwest Italy. Am. Assoc. Stratigr. Palynol. Contr. Ser., 17:105-127.

Stockmarr, J., 1971. Tablets with spores used in absolute pollen analysis. Pollen et Spores, 13:615-621.

Stover, L. E., 1977. Oligocene and early Miocene dinoflagellates from Atlantic corehole 5/5B, Blake Plateau. Am. Assoc. Stratigr. Palynol., Contr. Ser., 5A:66-89.

Talwani, M., Udintsev, G., et al., 1976. Init. Repts. DSDP, 38: Washington (U.S. Govt. Printing Office).

Williams, G. L., 1975. Dinoflagellate and spore stratigraphy of the Mesozoic-Cenozoic, offshore eastern Canada. Geol. Surv. Can., Paper 74-30, 2:107-161.

1977. Dinocysts: their paleontology, biostratigraphy, and paleoecology. In Ramsay, A. T. S., (Ed.), Oceanic Micropalaeontology: London (Academic Press), 1231-1325.

Williams, G. L., and Brideaux, W. W., 1975. Palynologic analyses of upper Mesozoic and Cenozoic rocks of the Grand Banks, Atlantic continental margin. Geol. Surv. Can. Bull., 236:1-162.

Williams, G. L., and Bujak, J. P., 1977. Cenozoic palynostratigraphy of offshore Eastern Canada. Am. Assoc. Stratigr. Palynol., Contr. Ser., $5 \mathrm{~A}: 14-47$.

1985. Mesozoic and Cenozoic dinoflagellates. In Bolli, H. M., Saunder, J. B., and Perch-Nielsen, K., (Eds.), Planktonic stratigraphy: Cambridge, U.K. (Cambridge Univ. Press), 847-964.

Date of initial receipt: 23 April 1987

Date of acceptance: 19 February 1988

Ms 104B-176 

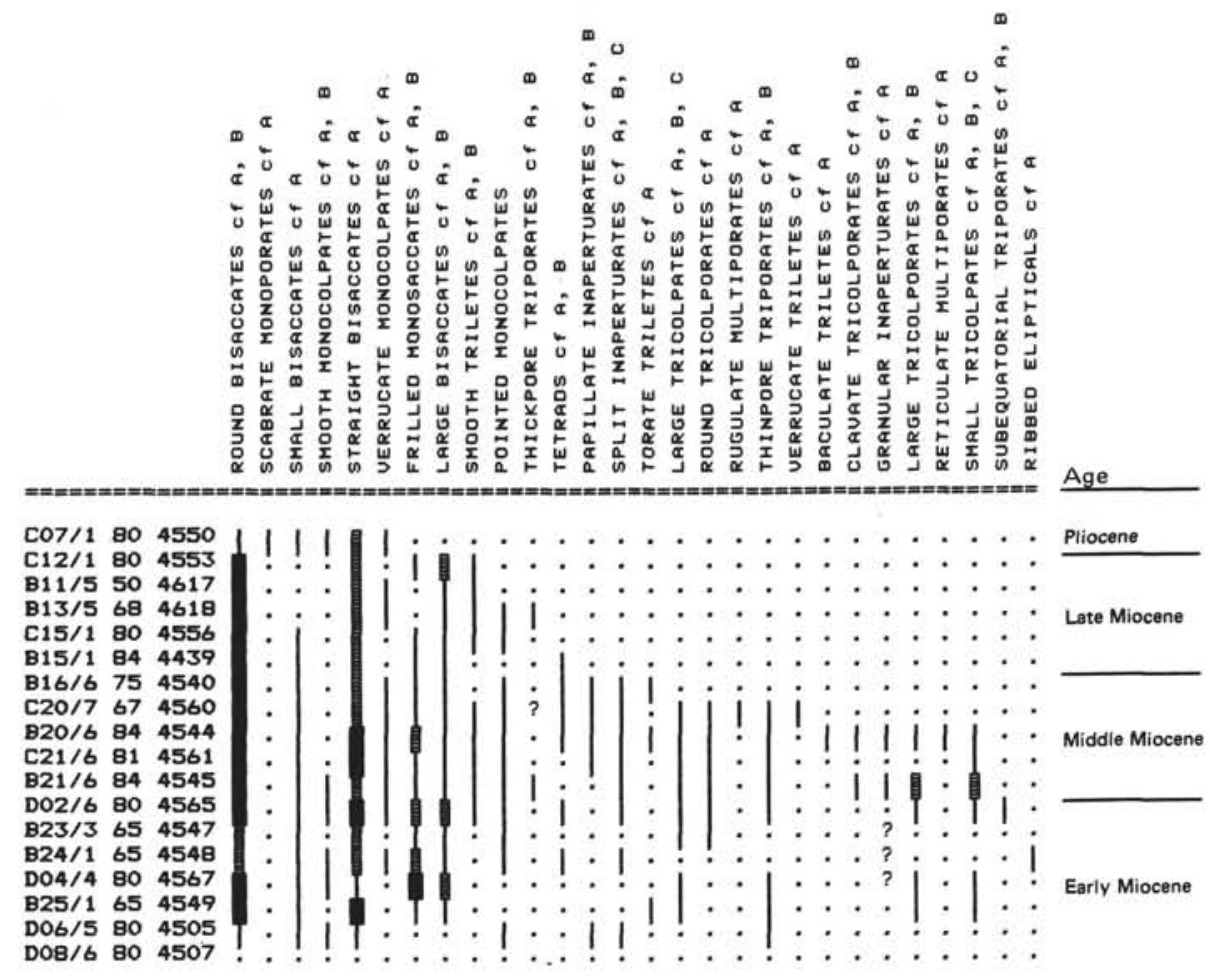

I Rare - Common Abundant ? Questionably Present

Figure 9. Range chart of pollen and spore types from Holes 642B, 642C, and 642D arranged in the sequence of last appearance.

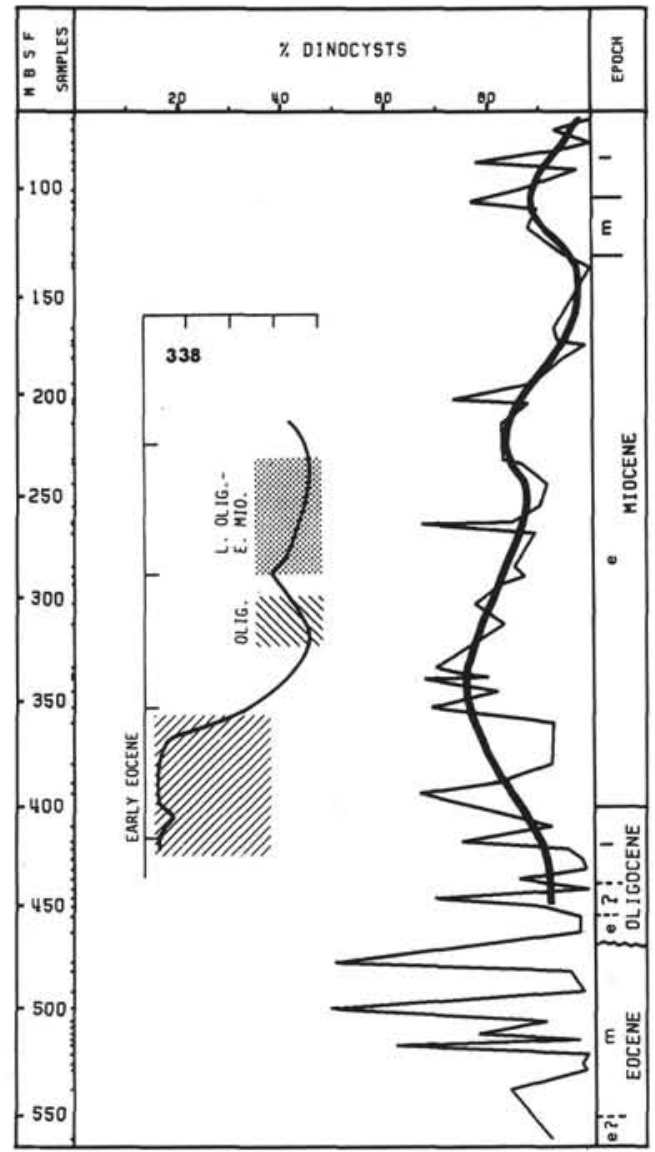

Figure 10. Absolute counts expressed as relative frequencies of marine and terrestrial palynomorphs, to compare with palyno-events recognized by Manum (1976, Fig. 3) at Site 338. 

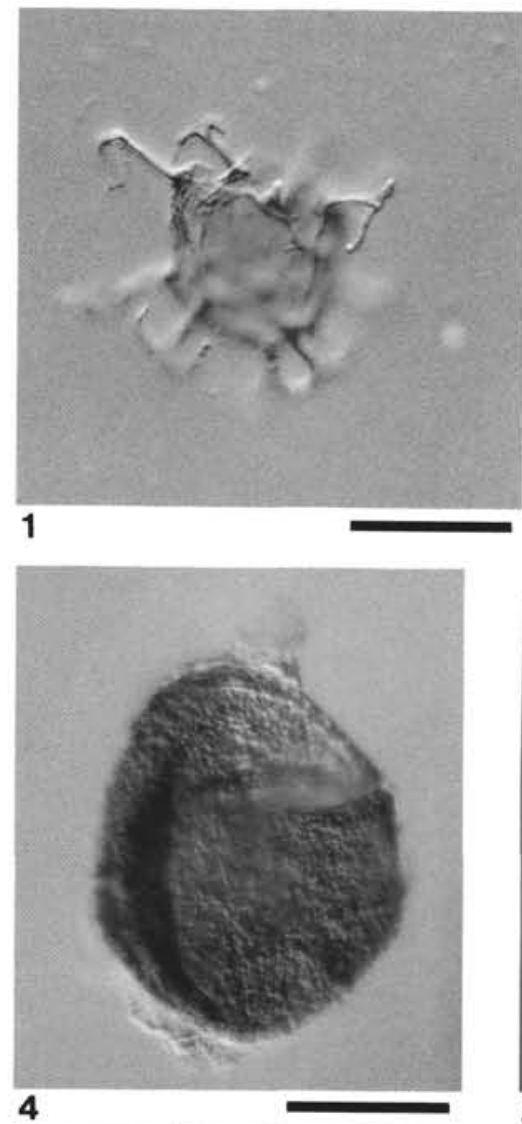

\section{4}

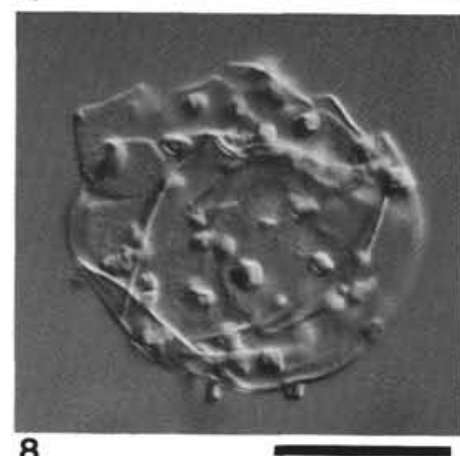

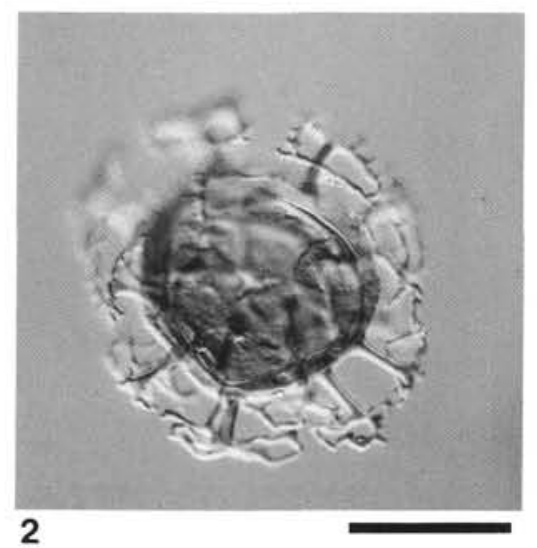

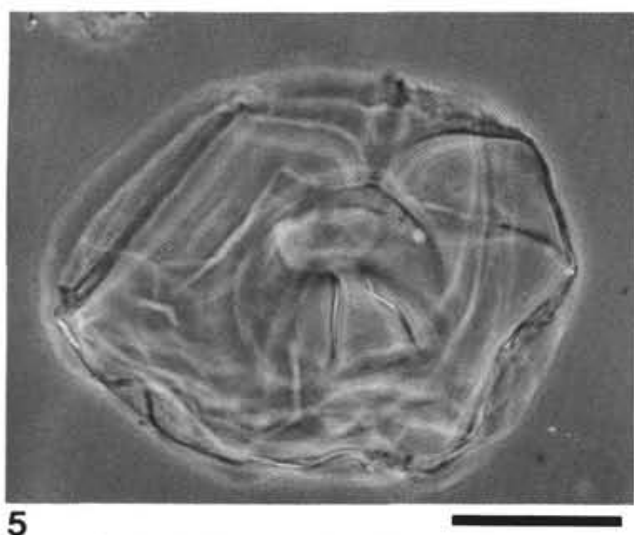

\section{5}

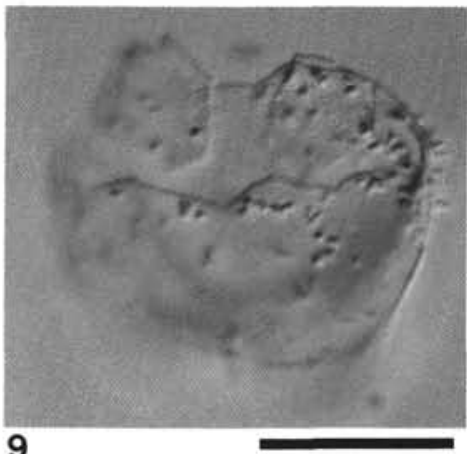

9

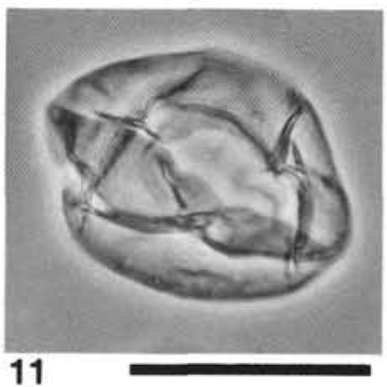

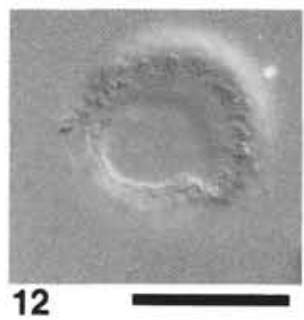

12

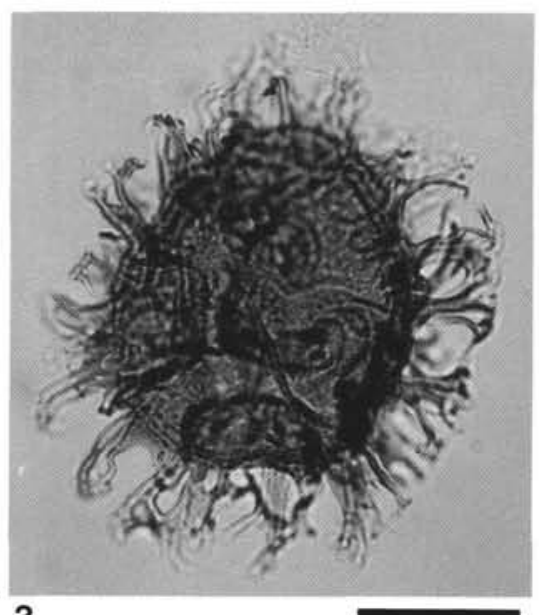

3

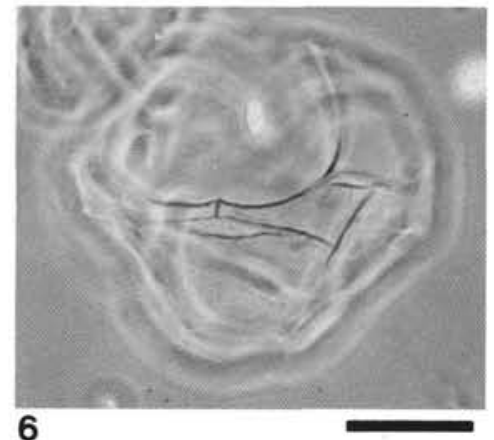

6

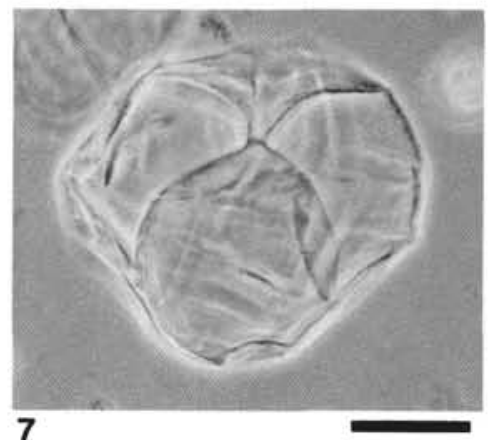

7
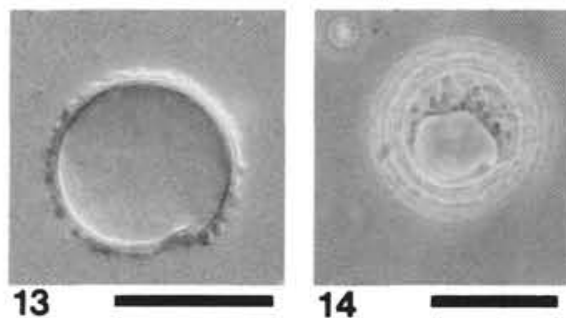

Plate 1. (Scale bars $=30 \mu \mathrm{m} ; \mathrm{Ph}=$ phase, $\mathrm{I}=$ interference, $\mathrm{B}=$ bright field). 1. Areosphaeridium arcuatum; 104-643A-48-6, 90-92 $\mathrm{cm}(\mathrm{I}) .2$. A. pectiniforme; 104-643A-51-4, 30-32 cm (I). 3. Areoligera sp. 1; 104-643A-47-1, 90-92 cm (B). 4. Aireiana sp. 1; 104-643A-49-4, 30-32 cm (I). 5. Amiculosphaera cf. umbracula 104-643A-8-6, 48-50 cm (Ph). 6-7. A. umbracula 104-642C-15-1, 79-81 cm (Ph). 8. Batiacasphaera baculata; 104-643A-39-1, 30-32 cm (I). 9. B. baculata; 104-643A-29-6, 30-32 cm (I). 10. B. sphaerica; 104-643A-22-5, 31-32 cm (B). 11. Batiacasphaera sp. 1; 104-643A-20-6, 30-32 cm. Apical, hi. (Ph). 12-14. Batiacasphaera sp. 2; 104-643A-12-1, 31-33 cm (12-13:I, 14:Ph). 12 and 14: apical, hi. 13: equatorial. 

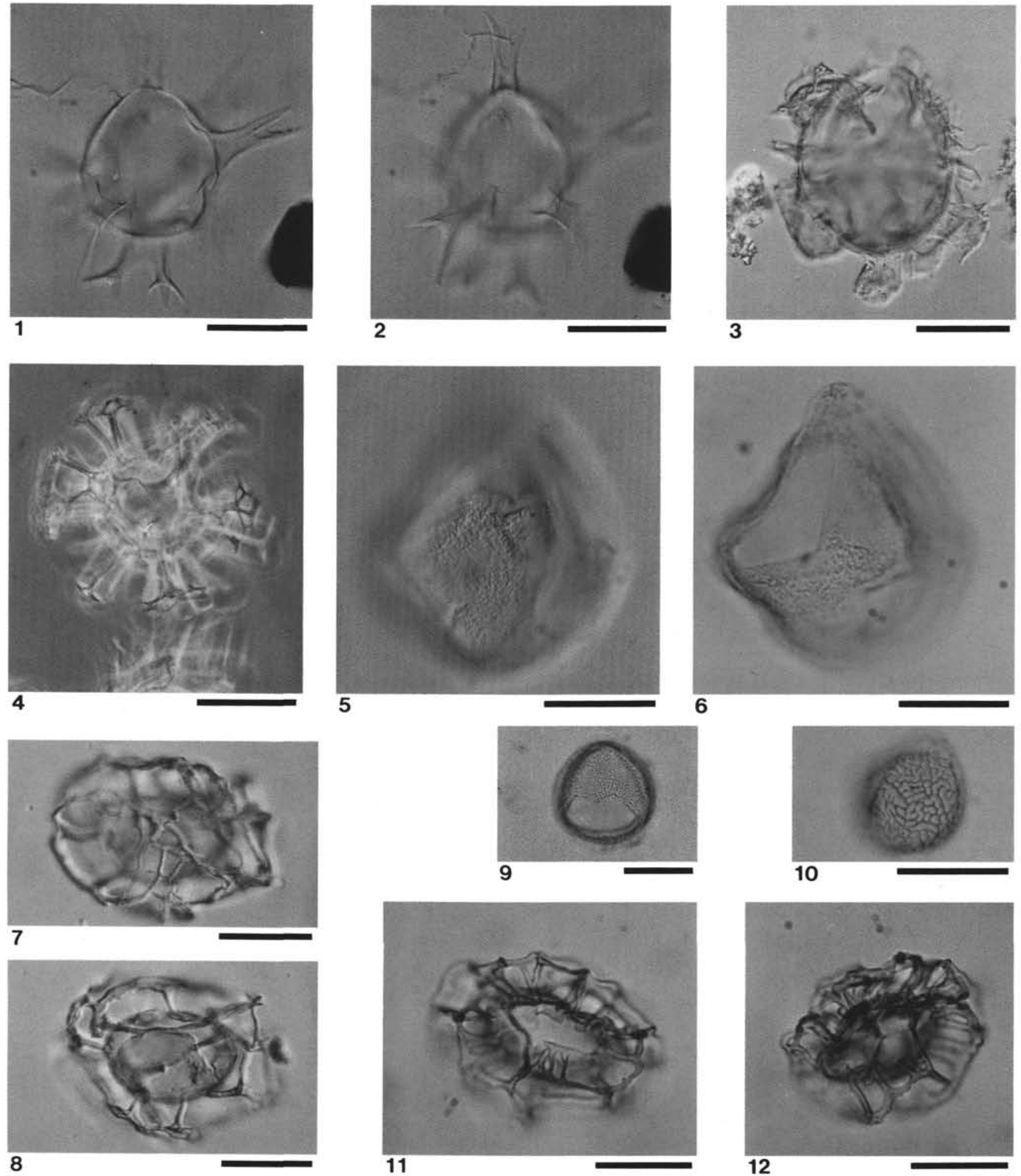

Plate 2. (Scale bars $=30 \mu \mathrm{m} ; \mathrm{Ph}=$ phase, $\mathrm{I}=$ interference, B = bright field). 1-2. Achomosphaera sp. 1; 104-643A-8-6, 48-50 cm (I). 1: equatorial. 2: ventral, lo. 3. Achilleodinium biformoides; 104-643A-60-2, 30-32 cm (I). 4. Achomosphaera andalousiensis; 104-643A-11-5, 30-32 cm (Ph). 5-6. Apteodinium tectatum; 104-643A-14-5, 32-34 cm (5:I, 6:B). 7-8. Adnatosphaeridium vittatum; 104-643A-57-5, 30-32 cm (I). 9. Bitectatodinium tepikiense; 104-642C-14-1, 79-81 cm (B). 10. Cerebrocysta bartonensis; 104-643A-54-1, 30-32 cm (B). 11-12. Adnatosphaeridium robustum; 104-643A-56-4, 30-32 cm (I). 

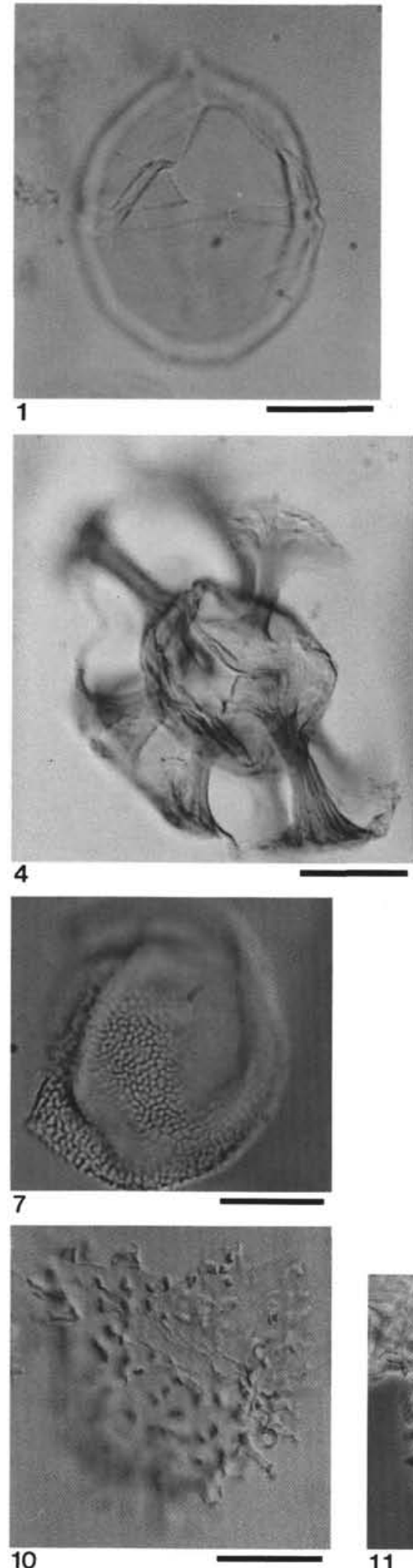

11

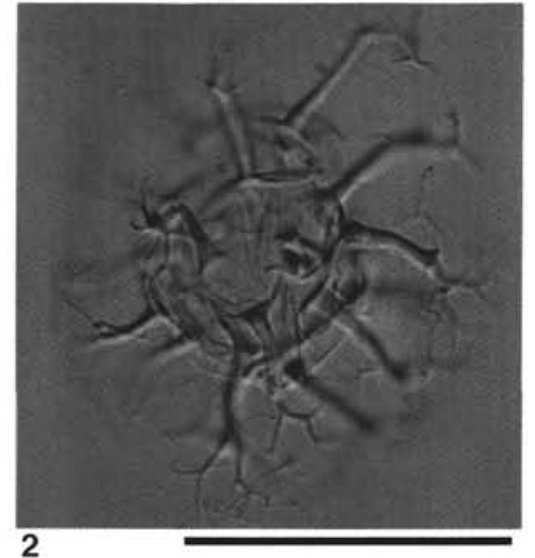

2
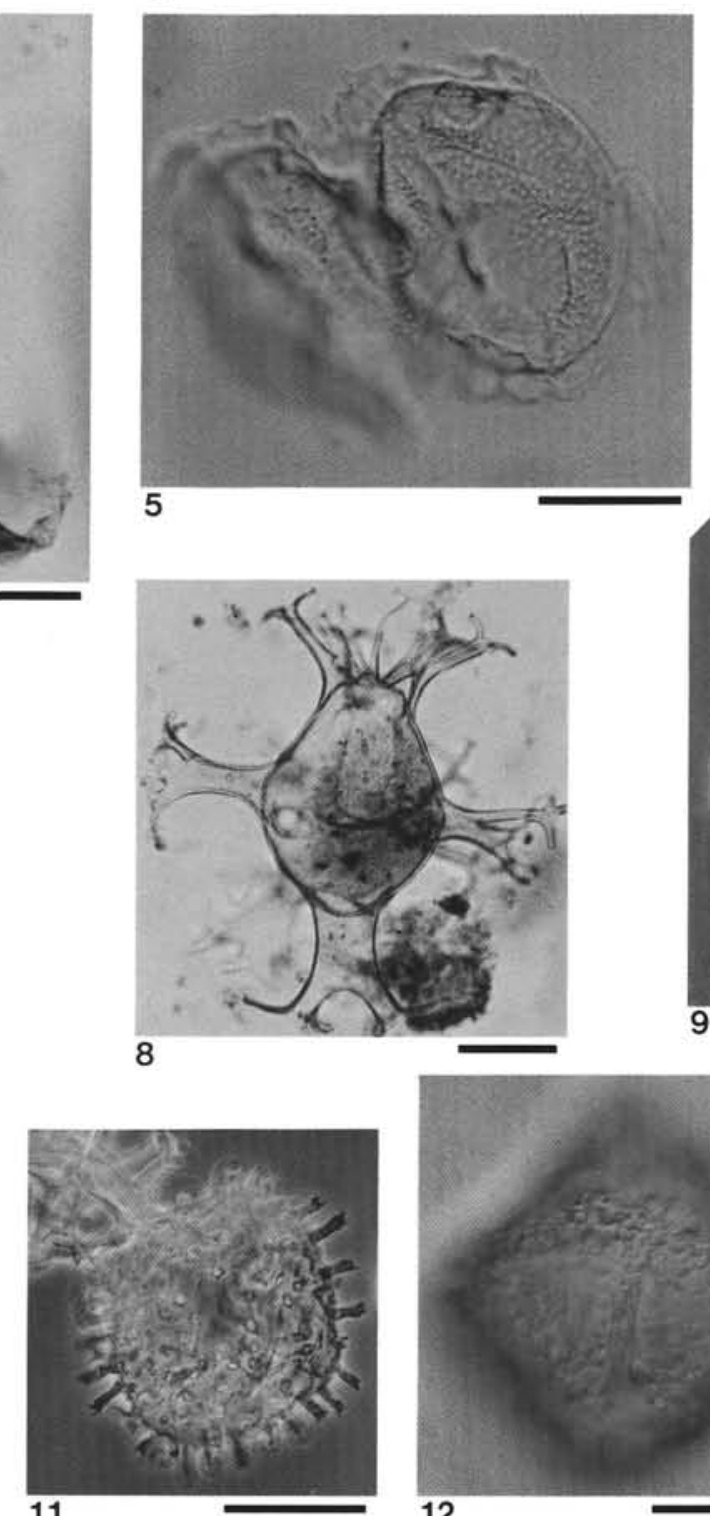

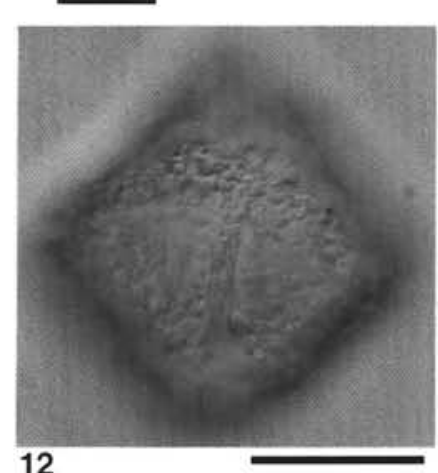

12
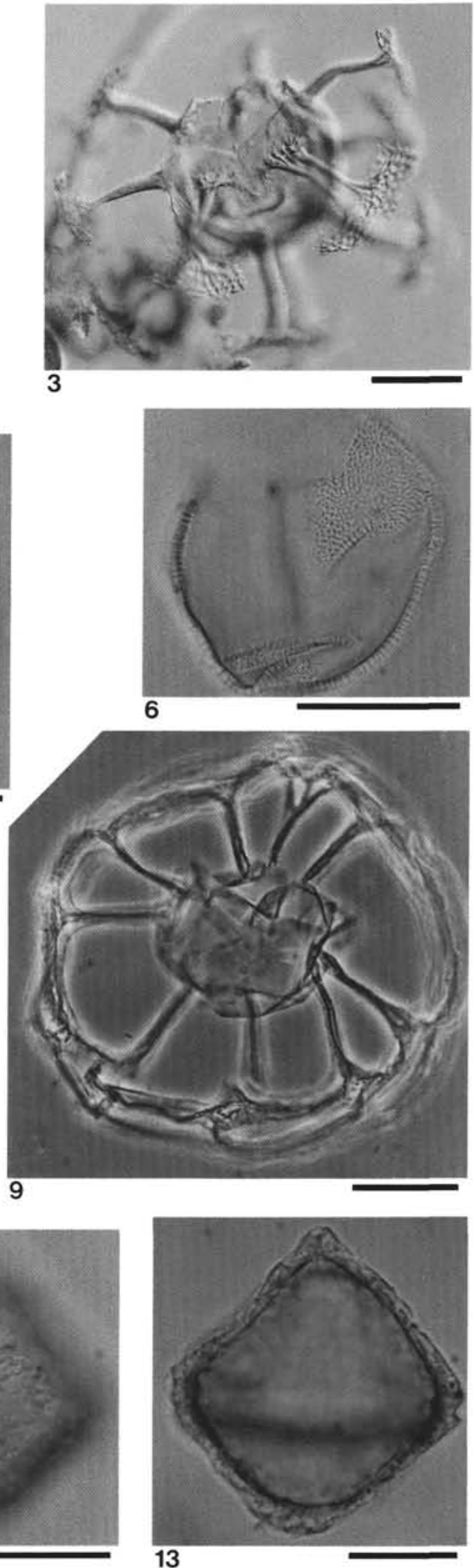

Plate 3. (Scale bars $=30 \mu \mathrm{m} ; \mathrm{Ph}=$ phase, $\mathrm{I}=$ interference, $\mathrm{B}=$ bright field). 1. Apteodinium australiense; 104-643A-33-1, 53-54 $\mathrm{cm}$ (B). 2. ?Areosphaeridium actinocoronatum; 104-643A-42-3, 19-21 cm (I). 3. A. diktyoplokus; 104-643A-54-1, 30-32 cm (I). 4. Araneosphaera araneosa; 104-643A-53-3, 30-33 cm (B). 5. Ascostomocystis granosa matsuoka 1983; 104-643A-29-6, 30-32 cm (I). 6. Batiacasphaera hirsuta; 104-643A-9-5, 30-32 cm (I). 7. Pyxidinopsis sp. 1; 104-643A-44-1, 19-21 cm (I). 8. Achomosphaera ramulifera; 104-642C-14-1, 79-81 cm (B). 9. ?Invertocysta sp. 1; 104-643A-29-6, 30-32 cm (Ph). Probably a new genus. Oblique dorsal, hi. 10-11. Cleistosphaeridium sp. 1; 104-643A-11-5, 30-32 cm. 10: hi. (I) 11: equatorial. $(\mathrm{Ph})$ 12-13. Emslandia spiridoides; 104-643A-20-6, 30-32 cm (12:I, 13:B). 

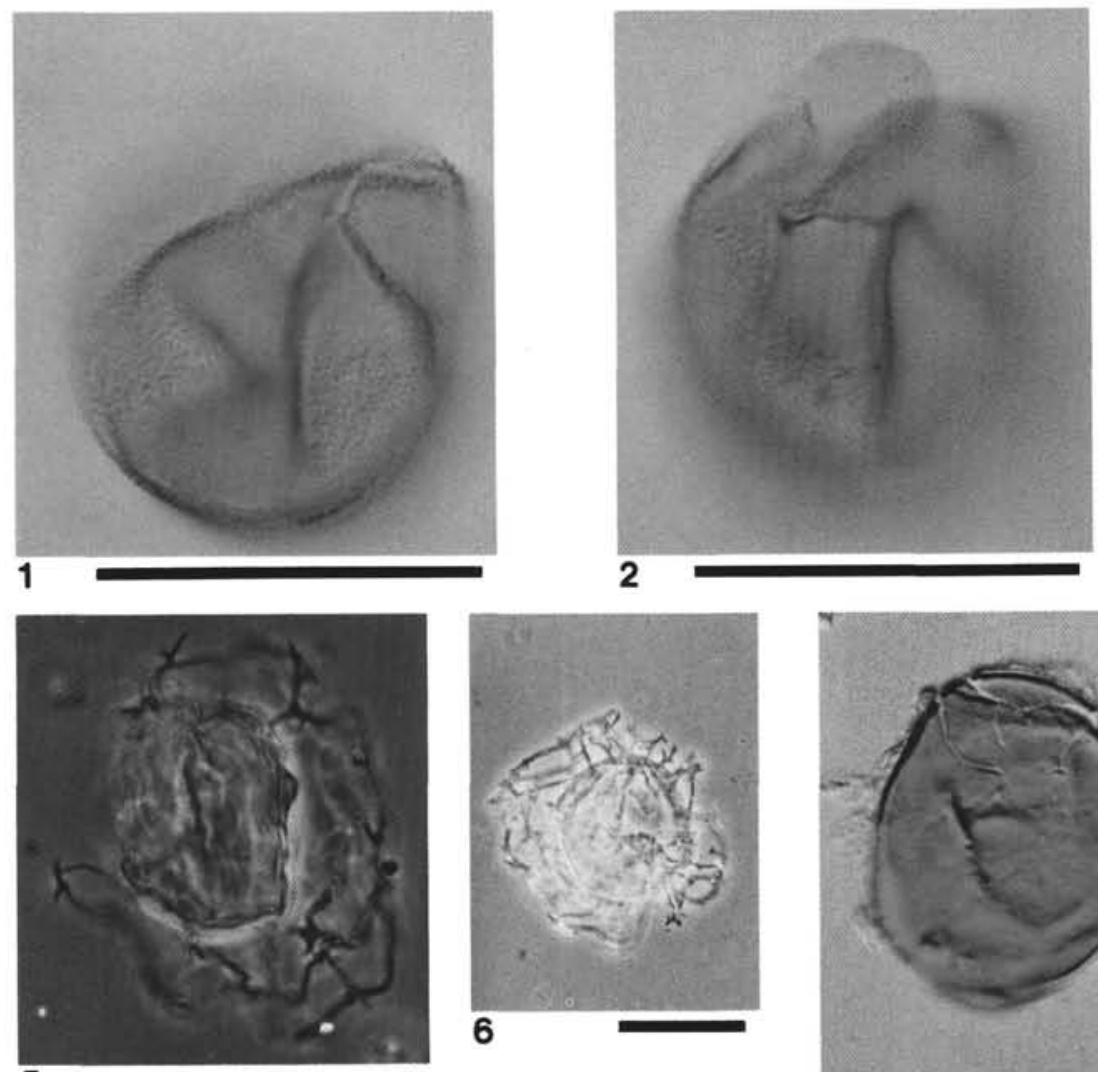

5
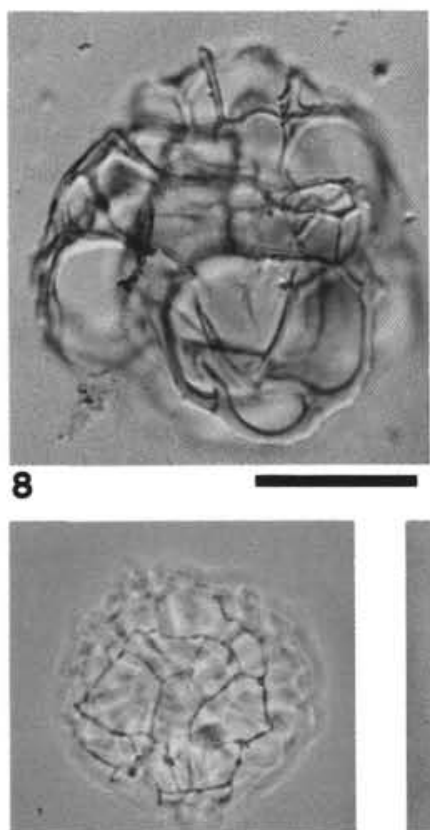

13
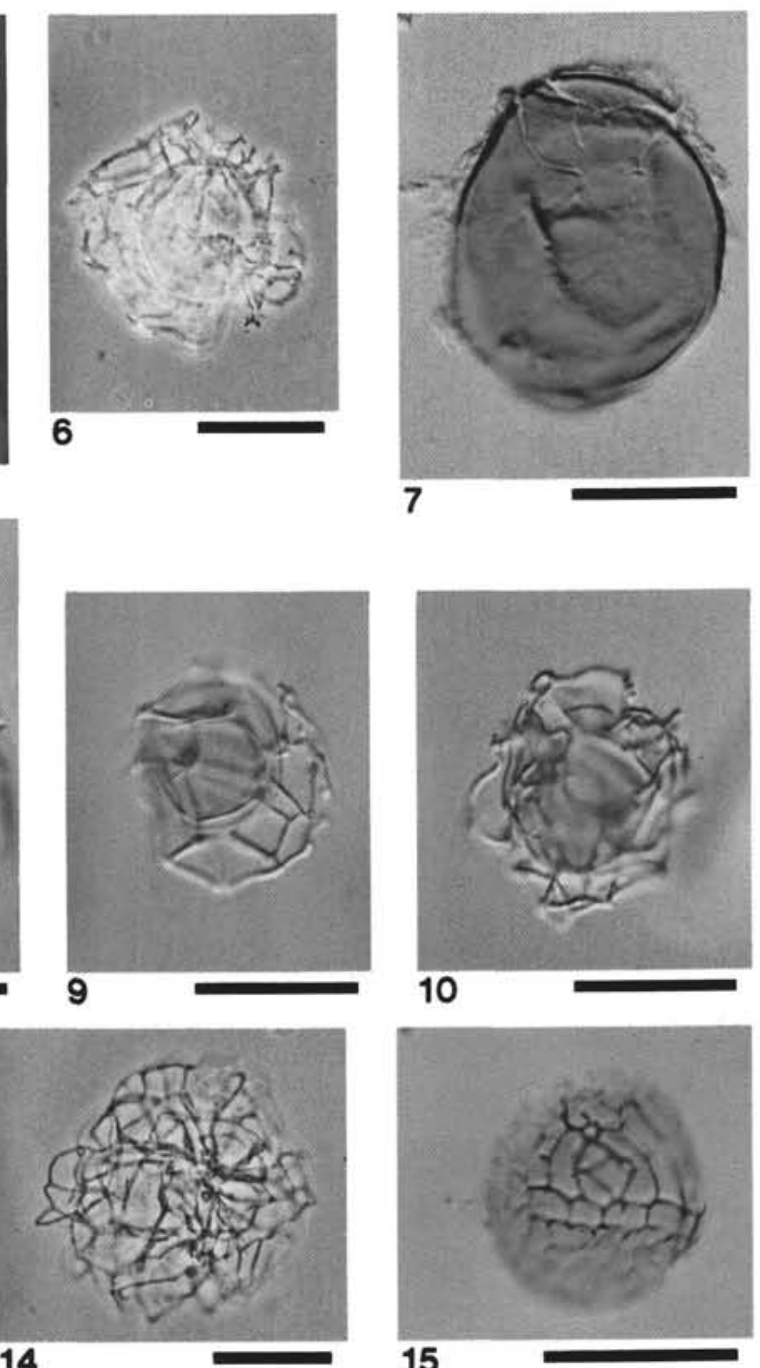
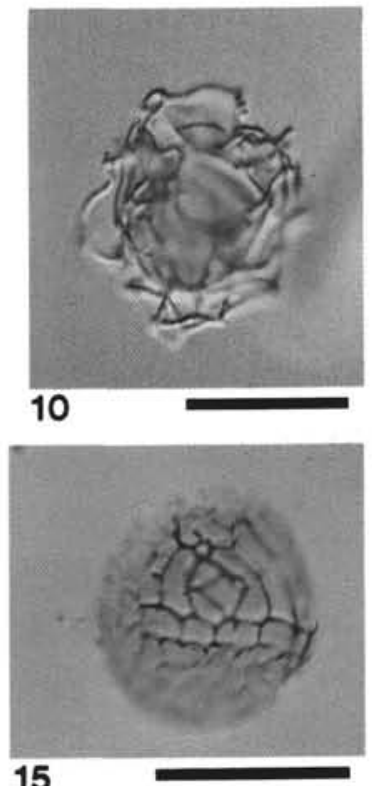

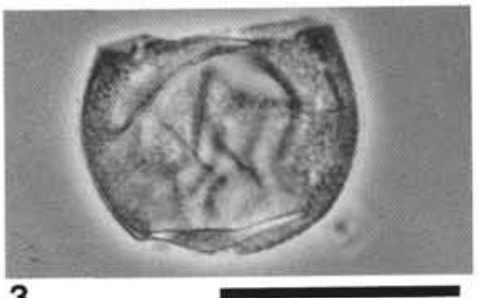

3

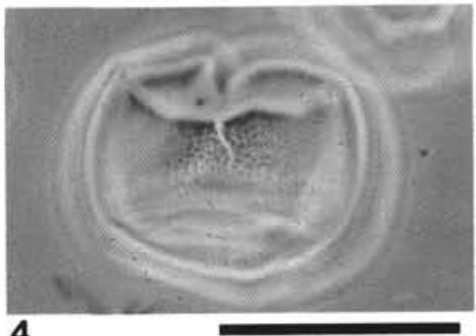

4
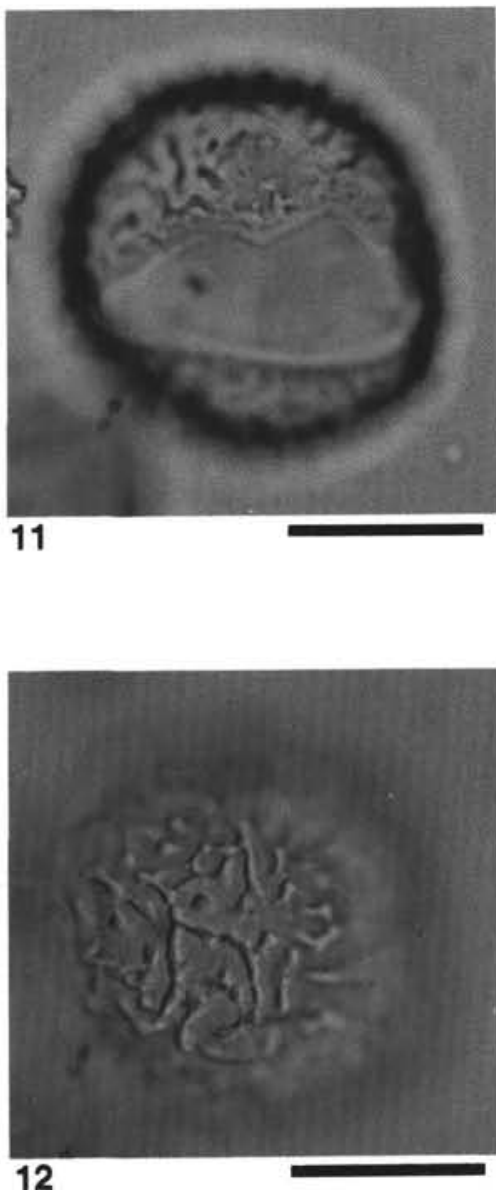

Plate 4. (Scale bars $=30 \mu \mathrm{m} ; \mathrm{Ph}=$ phase, $\mathrm{I}=$ interference, $\mathrm{B}=$ bright field). 1-2. Batiacasphaera micropapillata; 104-643A-41-1, 18-20 cm (I). 3-4. B. micropapillata; $104-643 \mathrm{~A}-37-3,20-22 \mathrm{~cm}(\mathrm{Ph})$. 5. Cannosphaeropsis utinensis; 104-643A-32-1, 30-32 cm (Ph). 6. C. utinensis; 104643A-12-5, 31-33 cm (Ph). 7. Caligodinium amiculum; 104-643A-42-1, 19-21 cm (B). 8. Cannosphaeropsis sp. 1; 104-643A-57-4, 30-32 cm (I). 9-10. Cannosphaeropsis sp. 2; 104-643A-55-6, 30-32 cm (I). 11-12. ?Bitectatodinium sp. 1; 104-643A-32-1, 30-32 cm. 11: ventral lo. (B), 12: ventral, hi. (I). 13. Cannosphaeropsis sp. A of Costa and Downie 1979; 104-642D-9-7, 27-30 cm (Ph). 14. Cannosphaeropsis sp. A of Costa \& Downie 1979; 104-643A-32-1, 30-32 cm (Ph). 15. Corrudinium incompositum; 104-643A-54-1, 30-32 cm (B). 

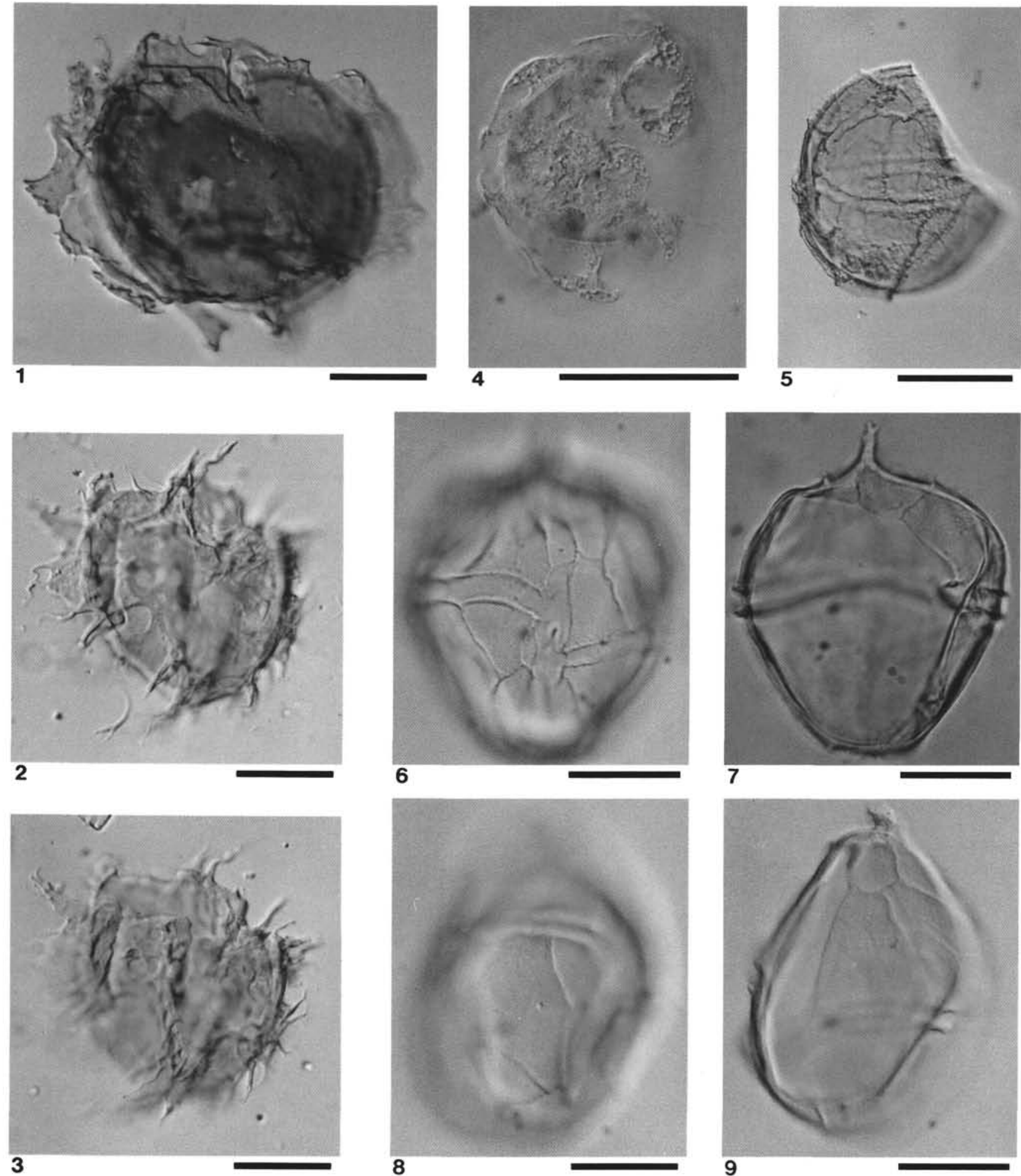

Plate 5. (Scale bars $=30 \mu \mathrm{m} ; \mathrm{Ph}=$ phase, $\mathrm{I}=$ interference, $\mathrm{B}=$ bright field). 1 . Chiropteridium lobospinosum; 104-643A-47-4, 90-92 $\mathrm{cm}$ (I). 2-3. C. mespilanum; 104-643A-44-2, 30-32 cm (I). 4. Cordosphaeridium sp. I of Manum 1976; 104-643A-15-6, 28-30 cm (I). 5. Cribroperidinium giuseppei; 104-643A-54-1, 30-32 cm (B). 6-7. C. giuseppei major; 104-643A-25-6, 30-32 cm (I). 8-9. C. tenuitabulatum; 104-643A-25-3, $30-32 \mathrm{~cm}(\mathrm{I})$. 

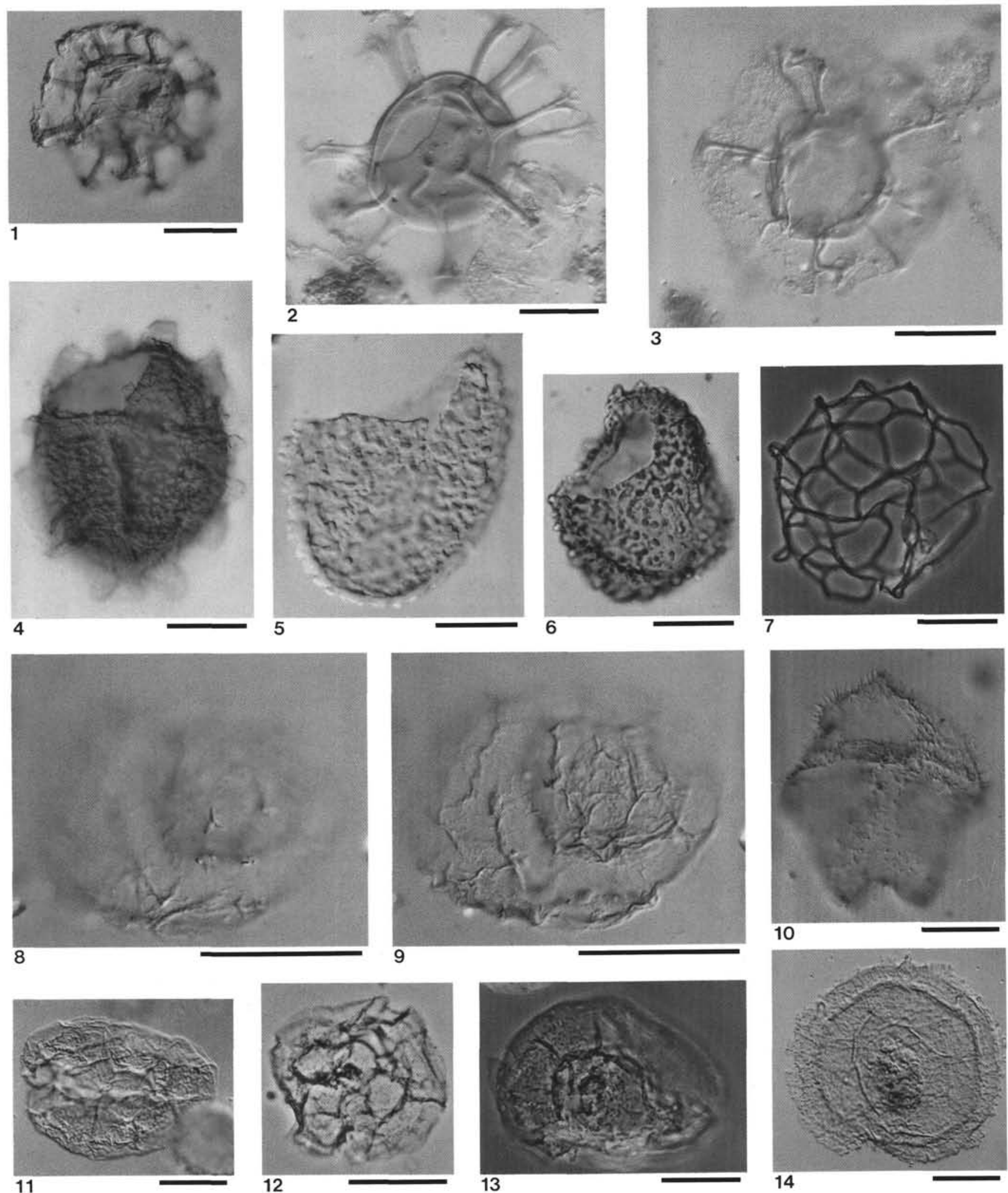

Plate 6. (Scale bars $=30 \mu \mathrm{m}, \mathrm{Ph}=$ phase, $\mathrm{I}=$ interference, $\mathrm{B}=$ bright field). 1 . Cordosphaeridium cantharellum; 104-643A-44-1, 30-32 cm (I). 2. C. inodes; 104-643A-60-2, 31-33 cm (B). 3. Eatonicysta ursulae; 104-643A-60-2, 31-33 cm (B). 4. Danea manicata; 104-643A-55-5, 30-32 $\mathrm{cm}$ (B). 5-6. Dinocyst 2; 104-643A-55-5, 30-32 cm (B). 7. Evittosphaerula paratabulata; 104-643A-29-6, 30-32 cm (Ph). 8-9. Gelatia sp. 1; 104643A-48-6, 90-92 cm (I). Note trifurcate processes on presumed dorsal hypocyst. 10. Trinovantedinium cf. capitatum; 104-643A-12-5, 31-33 cm (I). 11. Heteraulacacysta campanula; 104-643A-46-5, 82-84 cm (I). 12. H. campanula; 104-643A-36-5, 30-32 cm (I). 13. H. campanula; 104643A-11-5, 30-32 cm (Ph). 14. H. porosa; 104-643A-51-1, 30-32 cm (I). 

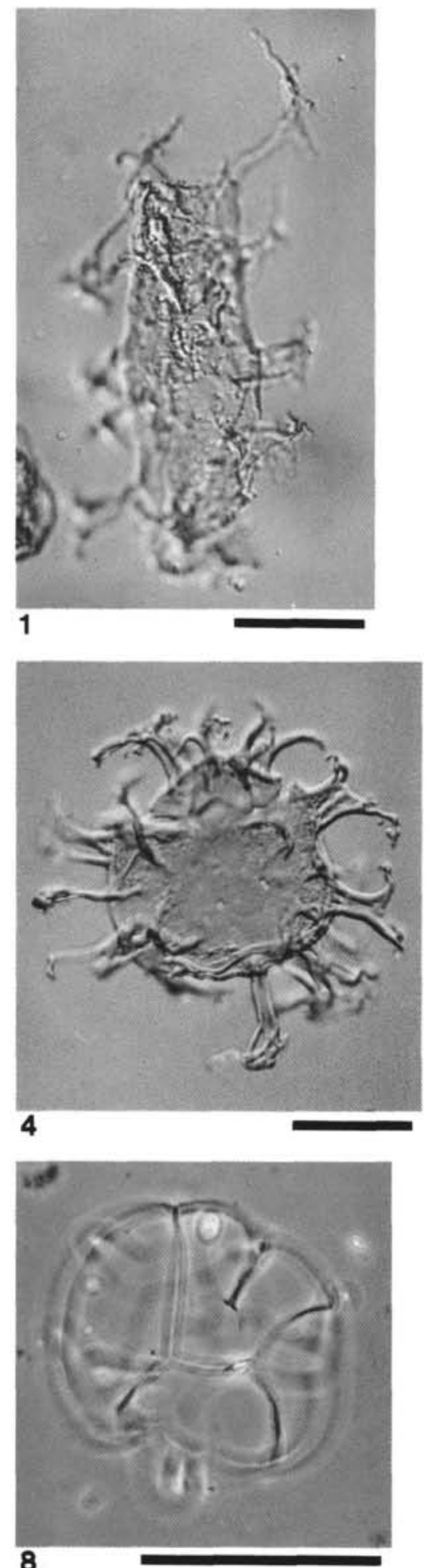

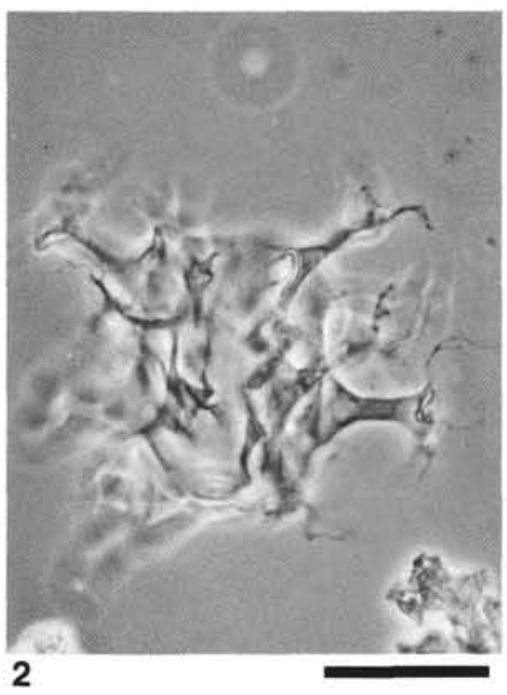

2
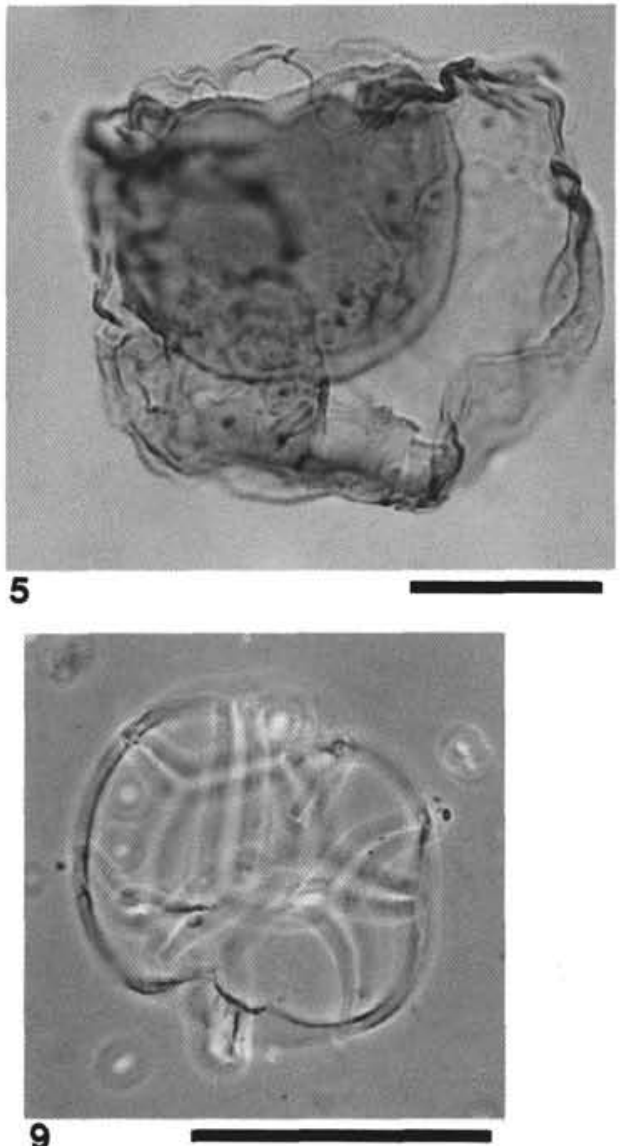

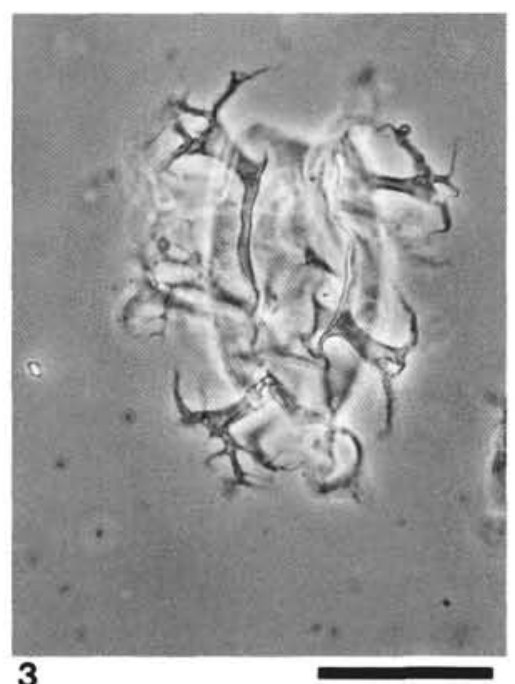

3
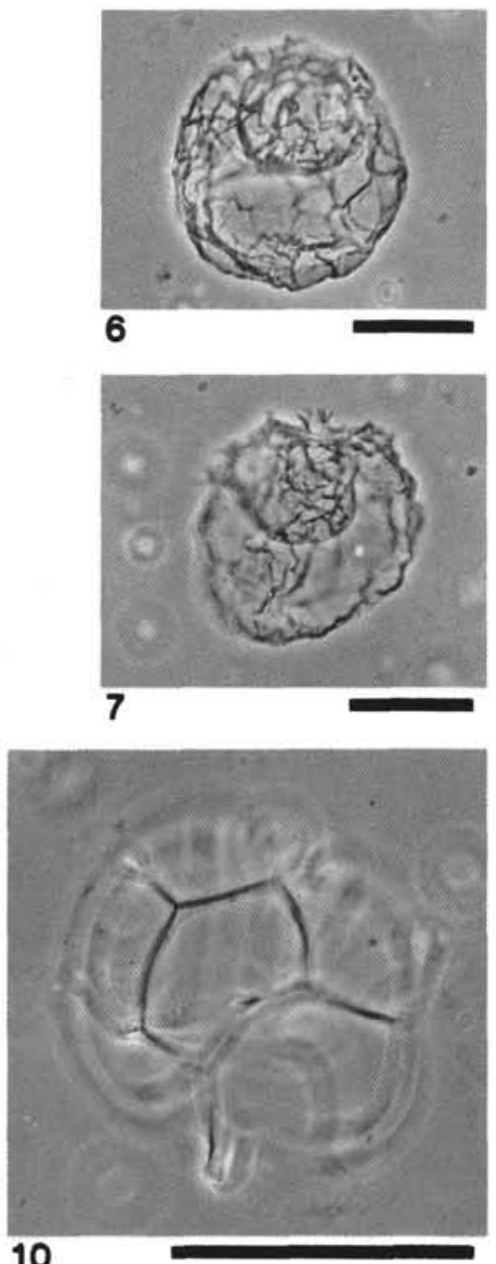

Plate 7. (Scale bars $=30 \mu \mathrm{m} ; \mathrm{Ph}=$ phase, $\mathrm{I}=$ interference, $\mathrm{B}=$ bright field). 1. Distatodinium ellipticum; 104-643A-51-1, 30-32 $\mathrm{cm}(\mathrm{I}) . \quad 2 . D$. craterum; 104-643A-32-1, 30-32 cm (Ph). 3. D. paradoxum (Brosius) Eaton 1976; 104-643A-33-1, 53-54 cm (Ph). 4. Glaphyrocysta intricata; 104-643A-47-1, 90-92 cm (I). 5. Glaphyrocysta cf. vicina; 104-643A-52-4, 28-30 cm (B). 6-7. Gelatia sp. 1; 104-643A-48-6, 90-92 cm (Ph). dorsal side up. 8-10. ?Evittosphaerula sp. 2; 104-642C-15-1, 79-81 cm (PH). 8: antapical, hi. 9: equatorial. 10: antapical, 10. 

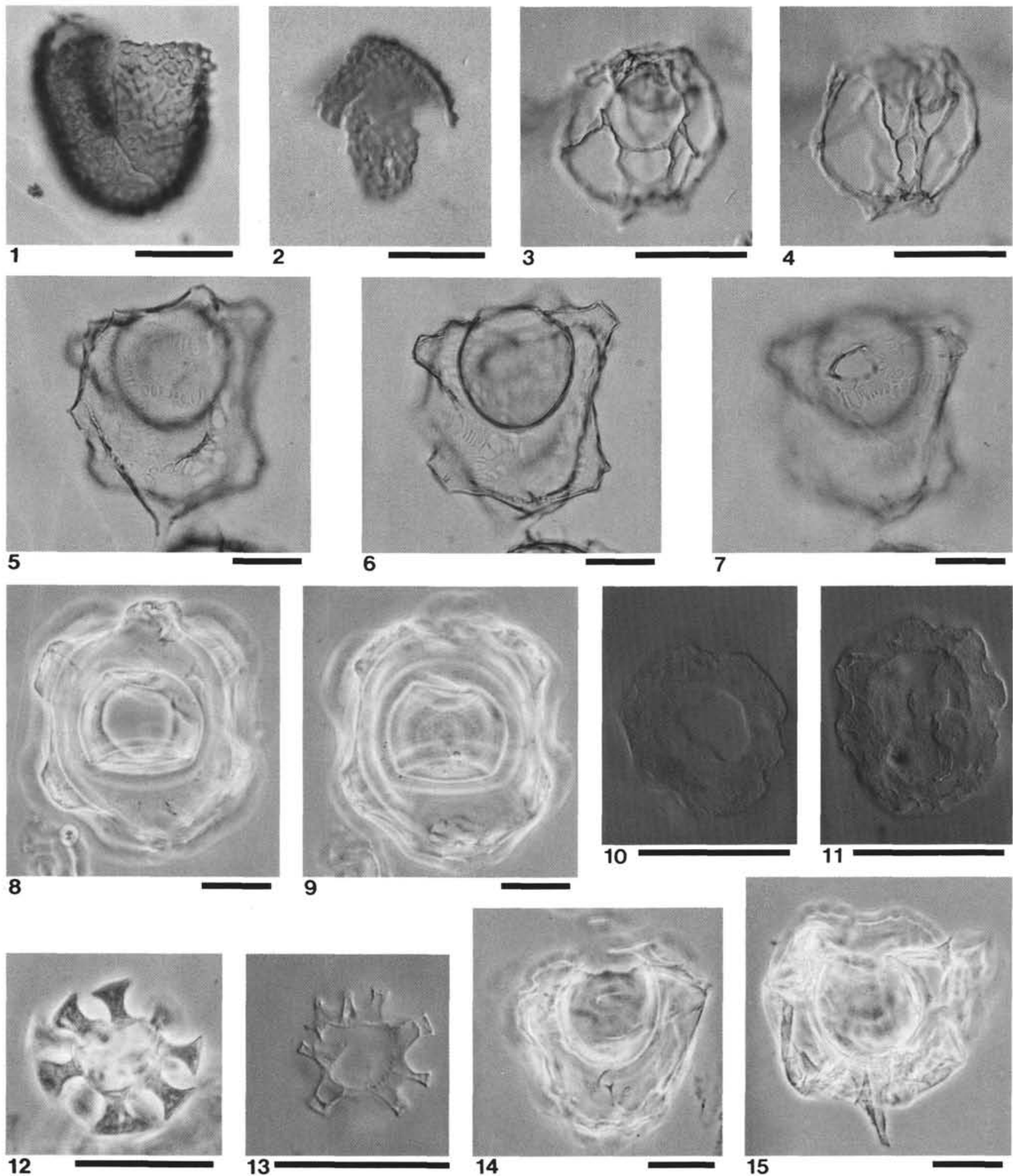

Plate 8. (Scale bars $=30 \mu \mathrm{m} ; \mathrm{Ph}=$ phase, $\mathrm{I}=$ interference, $\mathrm{B}=$ bright field). 1-2. Dinocyst $1 ; 104-643 \mathrm{~A}-57-4,30-32 \mathrm{~cm}$ (B). 2: shows the operculum. 3-4. Dinocyst 3 (?Evittosphaerula sp. 1); 104-643A-48-6, 90-92 cm (I). 5-7. Dinocyst 4; 104-643A-24-5, 30-32 cm (B). 5: left lateral, hi. 6: equatorial. 7: left lateral, lo. 8-9. Dinocyst 6; 104-643A-23-2, 81-84 cm (Ph). 10-11. Dinocyst 7; 104-643A-12-5, 31-33 cm (I). 10: antapical, lo. 11: hi. 12. Dinocyst II of Manum 1976; 104-642C-21-6, 30-32 cm (Ph). 13. Dinocyst IV of Manum 1976; 104-643A-32-1, 30-32 cm (I). 14. Dinocyst 5; 104-643A-24-5, 30-32 cm. Dorsal, hi. (Ph) 15. Dinocyst 5; 104-643A-27-5, 31-33 cm. Equatorial. (Ph). 


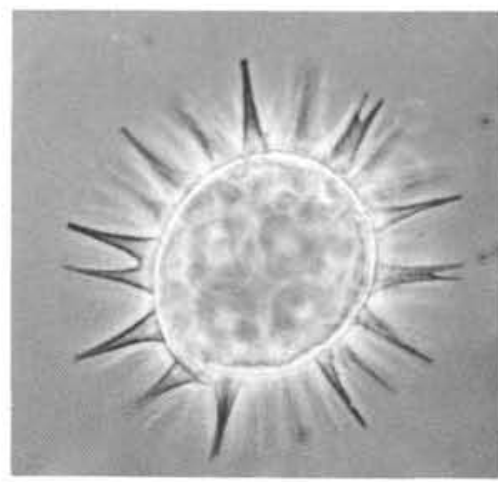

1
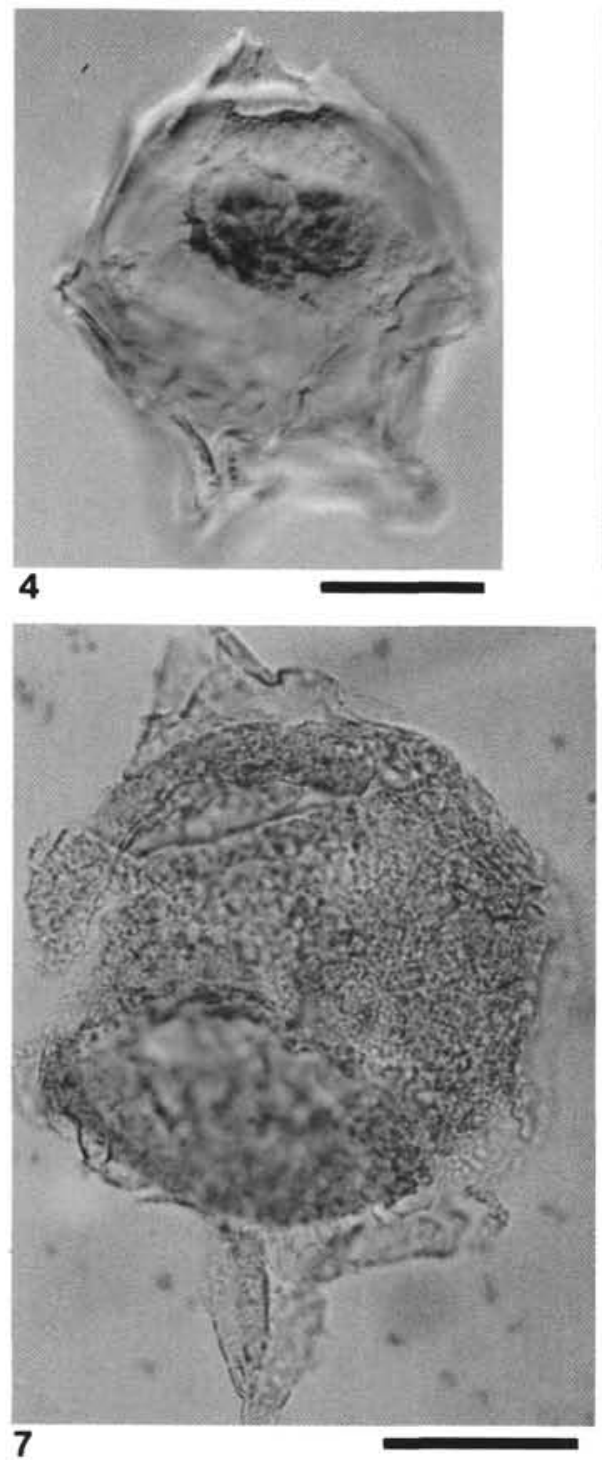

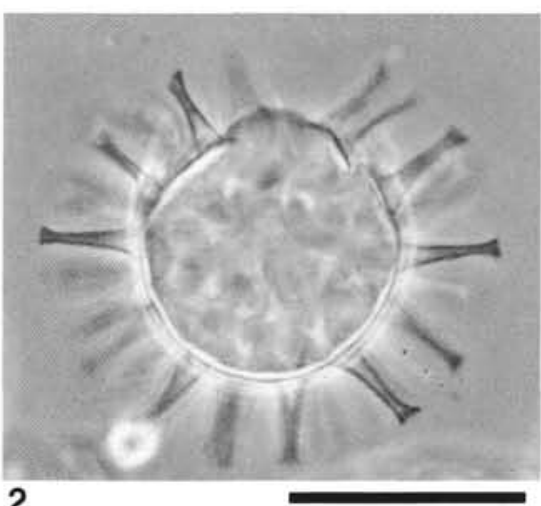

2
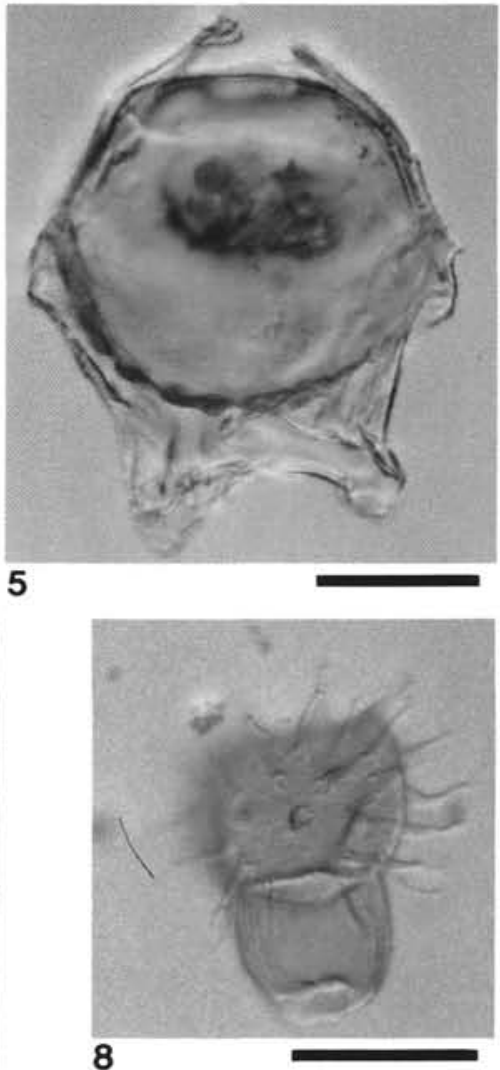

8

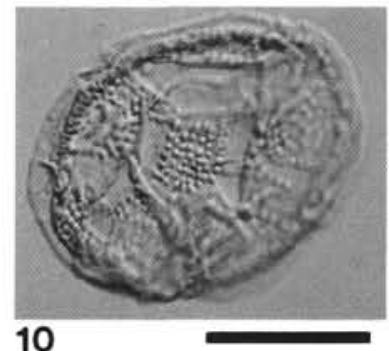

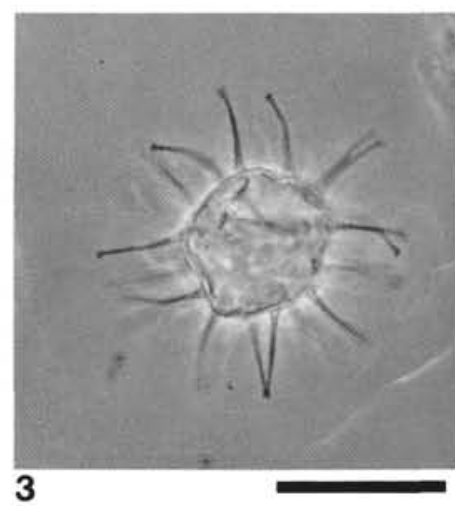

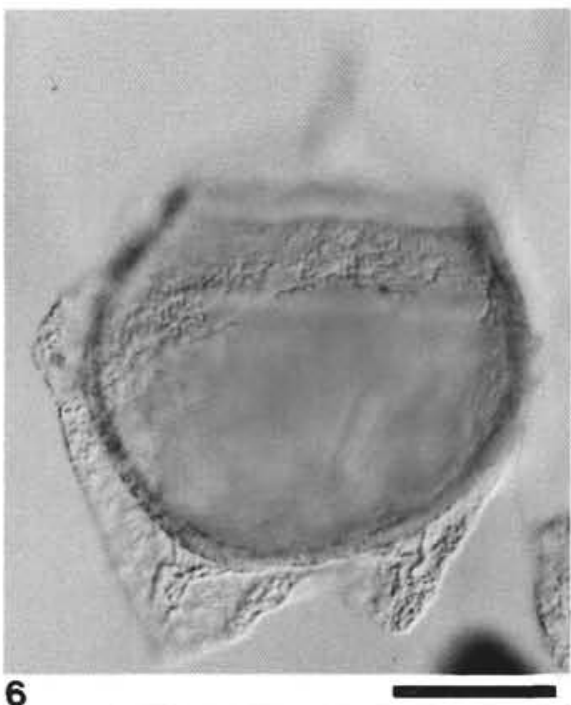

6

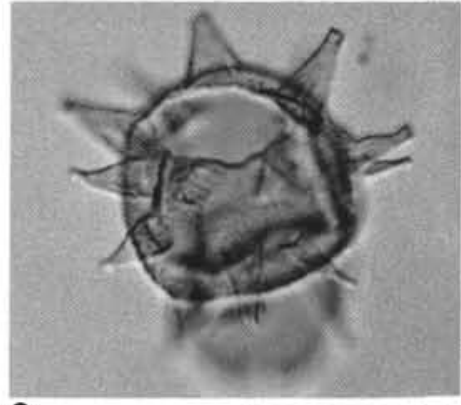

9
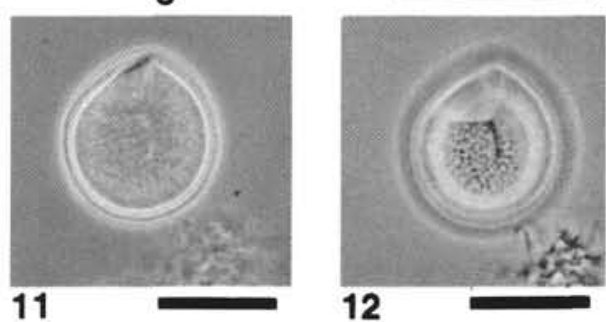

Plate 9. (Scale bars $=30 \mu \mathrm{m} ; \mathrm{Ph}=$ phase, $\mathrm{I}=$ interference, $\mathrm{B}=$ bright field). 1. Dapsilidinium pastielsii; $104-643 \mathrm{~A}-8-6,48-50 \mathrm{~cm}(\mathrm{Ph}) . \quad 2 . D$. pseudocolligerum; 104-643A-32-1, 30-32 cm (Ph). 3. Dapsilidinium sp. 1; 104-643A-16-1, 30-32 cm (Ph). 4-5. Deflandrea phosphoritica; 104643A-48-5, 90-92 cm (I). 6. D. cf. phosphoritica; 104-643A-53-3, 30-33 cm (I). 7. Deflandrea sp. B of Powell 1986a; 104-643A-50-1, 30-32 cm (B). All specimens in state of bad preservation; this one is among the best preserved. 8. Diphyes cf. colligerum; 104-643A-60-2, 31-33 cm (B). 9. Diphyes sp. 1; 55-5, 30-32 cm (B). 10. Dinopterygium cladoides sensu Morgenroth 1966; 104-643A-51-3, 30-32 cm (I). 11-12. Filisphaera filifera; 104-643A-12-4, 31-33 cm (Ph). 

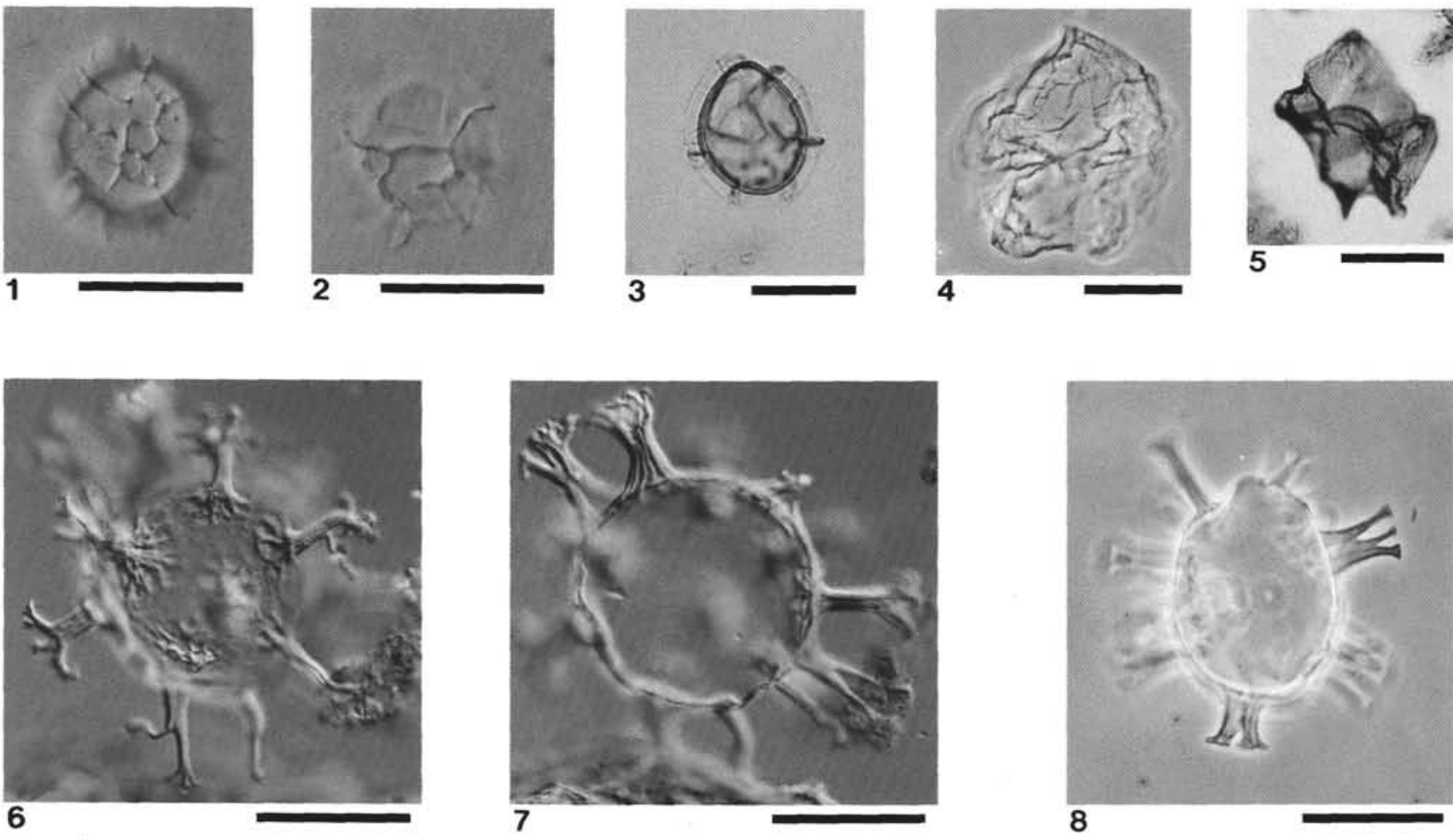

6

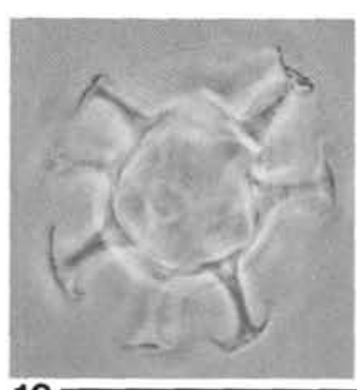

10
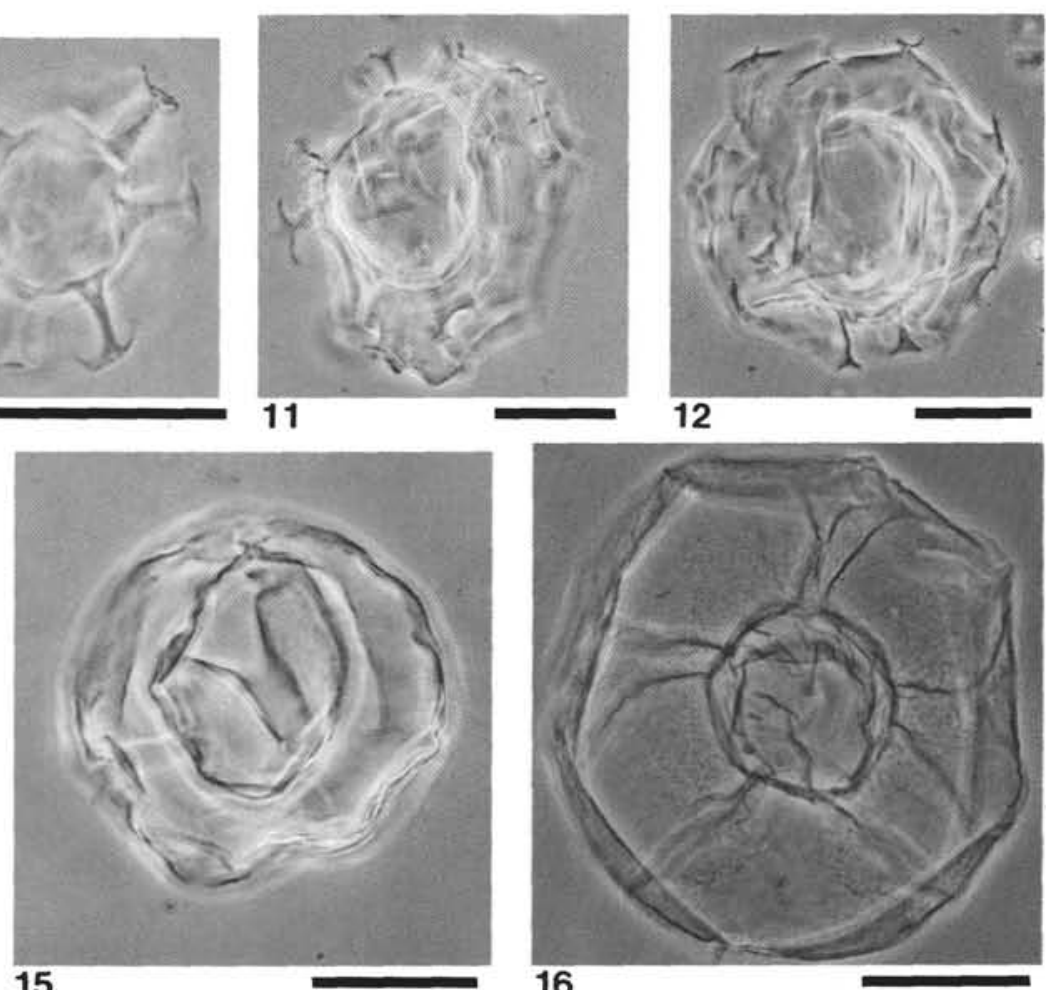

16

Plate 10. (Scale bars $=30 \mu \mathrm{m} ; \mathrm{Ph}=$ phase, $\mathrm{I}=$ interference, $\mathrm{B}=$ bright field). 1-2. Gen. et sp. indet. of Piasecki 1980; 104-643A-11-5, 30-32 cm (I). 1: dorsal, lo. 2: dorsal, hi. 3. Gen. et sp. indet. of Piasecki 1980; 104-642C-22-5, 67-70 cm (B). Probably a Corrudinium sp. Equatorial. 4. Lejeunecysta cf. hyalina; 104-643A-15-6, 28-30 cm (Ph). 5. L. fallax; 104-643A-12-1, 31-33 cm (B). 6-7. Homotryblium floripes; 104-643A-46-5, 82-84 cm (I). 8. H. vallum; 104-643A-11-5, 30-32 cm (Ph). 9. Hystrichosphaeridium latirictum; 104-643A-46-5, 82-84 cm (I). 10. H. latirictum; 104-643A-25-2, 30-32 cm (Ph). 11. Hystrichostrogylon cf. membraniphorum; 104-643A-12-1, 31-33 cm (Ph). 12. Hystrichostrogylon sp. of Edwards 1984; 104-643A-12-1, 31-33 cm (Ph). 13. Hystrichosphaeridium sp. 1; 104-643A-18-1, 31-33 cm (Ph). Left lateral, hi. 14. Hystrichosphaeridium sp. $1 ; 104-643 \mathrm{~A}-20-6,30-32 \mathrm{~cm}(\mathrm{Ph})$. Equatorial. 15. Invertocysta lacrymosa; 104-643A-13-6, 31-33 cm (Ph). 16. I. tabulata; 104-643A-13-4, 31-33 cm (Ph). 

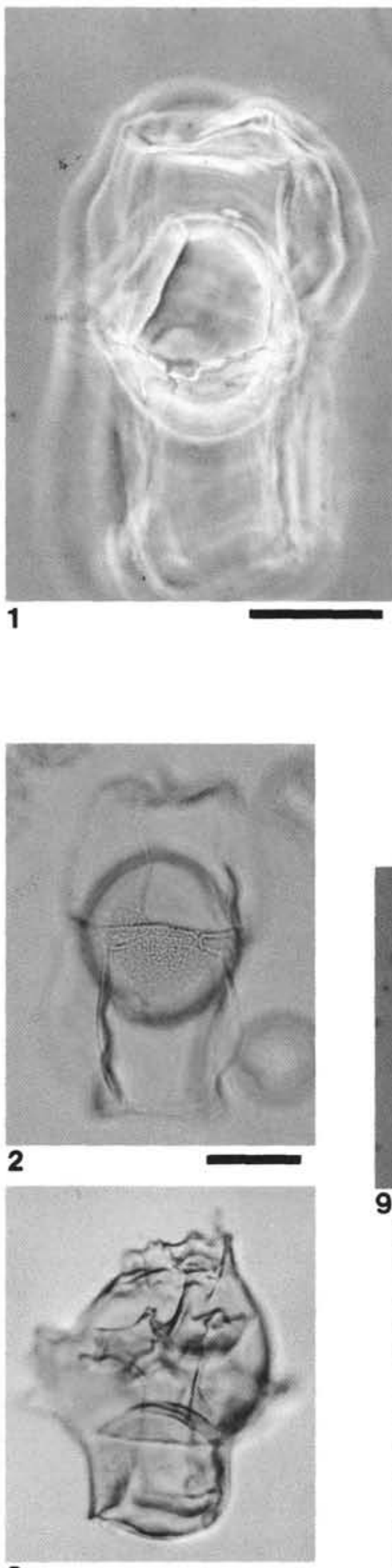

3
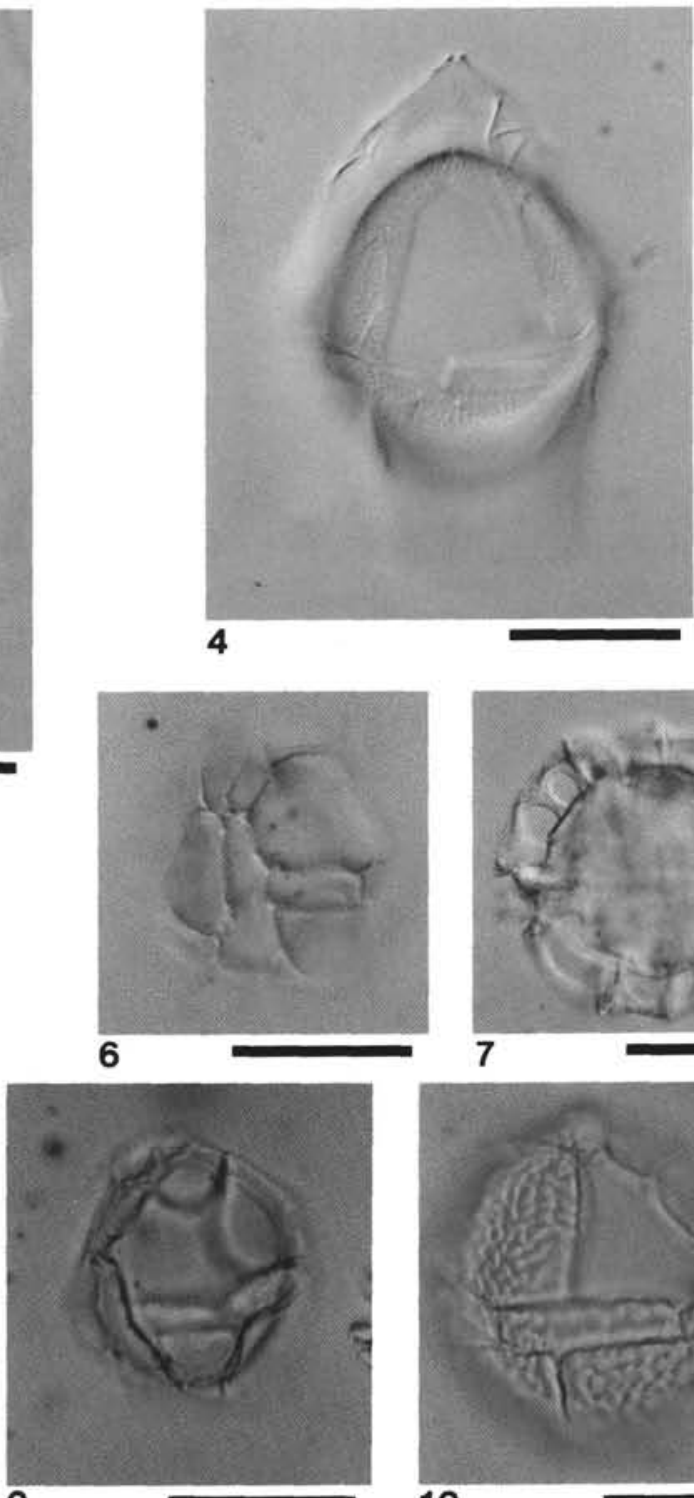

9

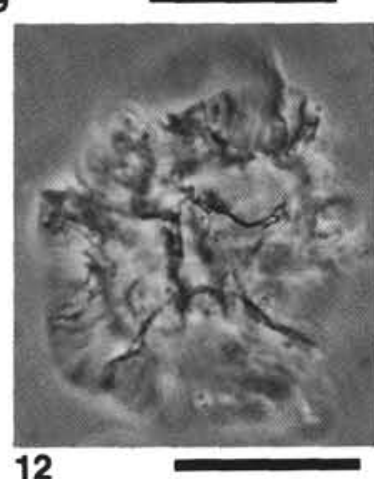

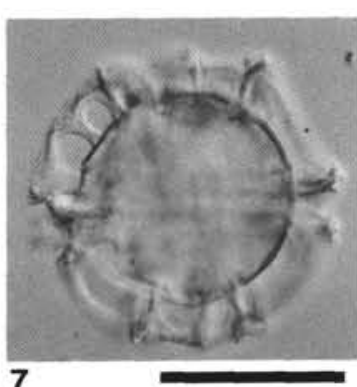

7

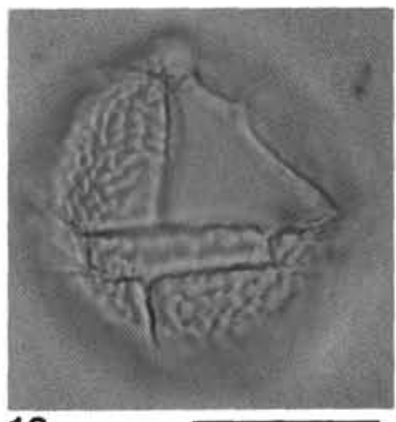

10

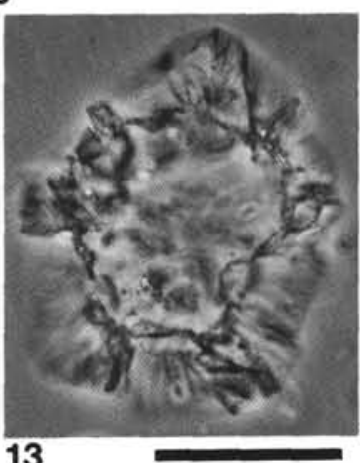

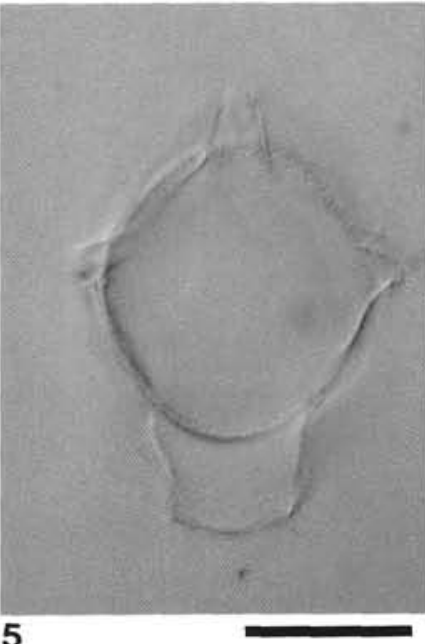

5
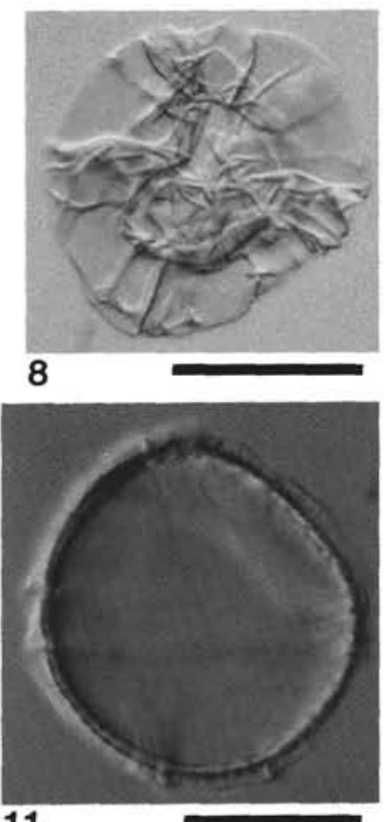

11

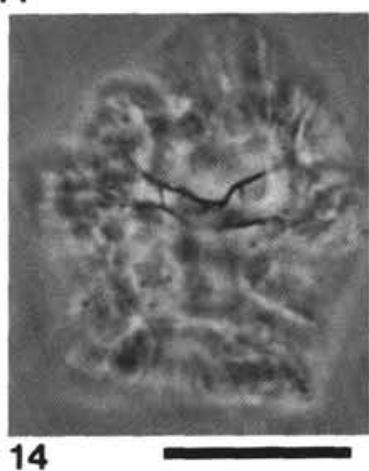

Plate 11. (Scale bars $=30 \mu \mathrm{m} ; \mathrm{Ph}=$ phase, $\mathrm{I}=$ interference, B = bright field). 1. Hystrichosphaeropsis obscura; 104-643A-15-6, 28-30 $\mathrm{cm}(\mathrm{Ph})$. With smooth endophragm. 2. H. obscura; 104-643A-12-4, 31-33 cm (I). With granular endophragm. 3. Hystrichosphaeropsis sp. 1; 104-643A-555, 30-32 cm (B). 4-5. H. cf. complanata; 104-643A-16-1, 30-32 cm (I). 6-7. Impagidinium aquaeductum; 104-643A-12-5, 31-33 cm (I). 8. I. velorum; 104-643A-55-5, 30-32 cm (B). 9. I. paradoxum; 104-643A-12-5, 31-33 cm (I). 10-11. I. maculatum; 104-643A-13-6, 31-33 cm (I). $12-$ 14. Impagidinium sp. 2; 104-643A-12-5, 31-33 cm (Ph). 12: ventral, hi. 13: equatorial. 14: ventral, lo. 

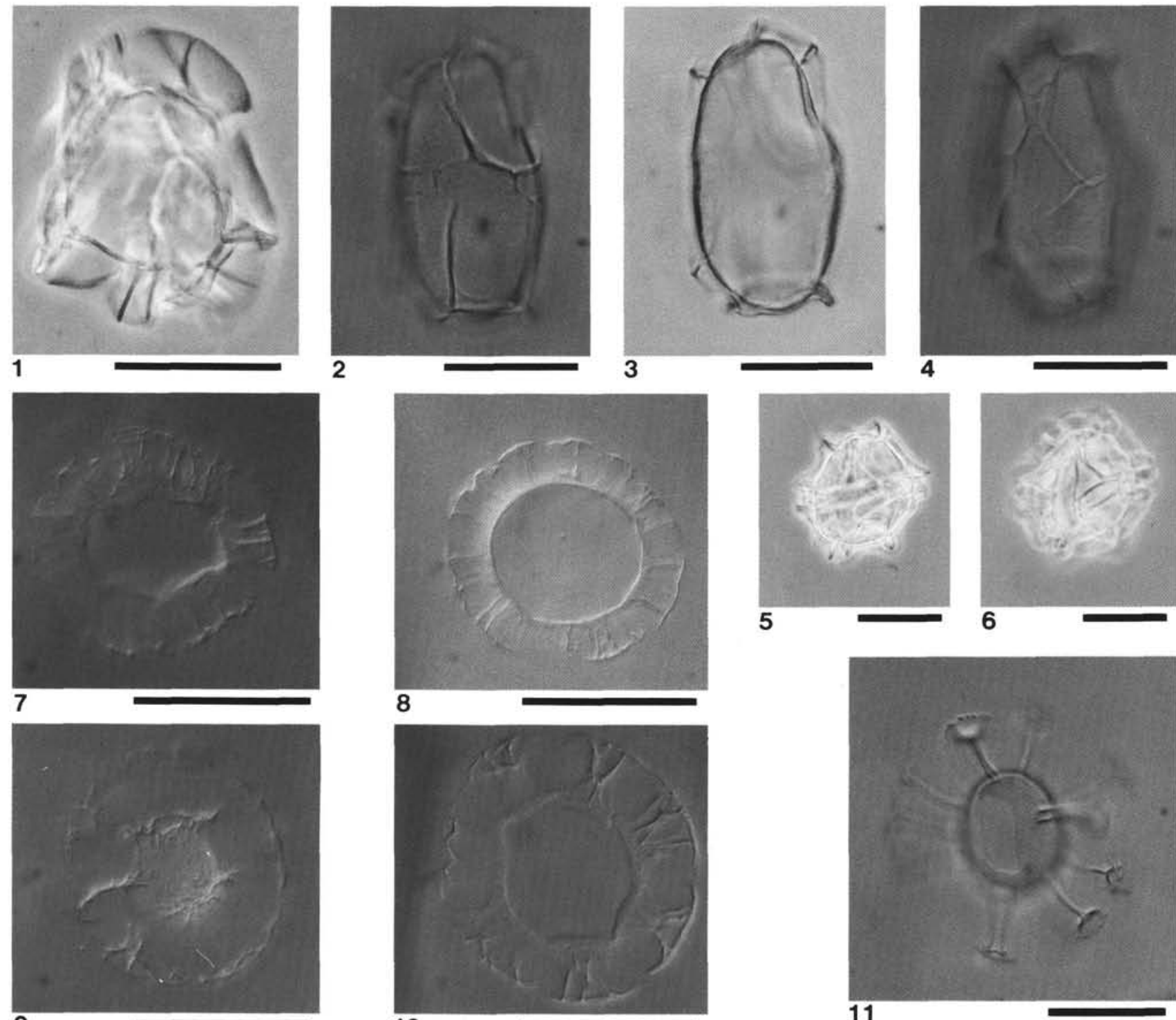

8

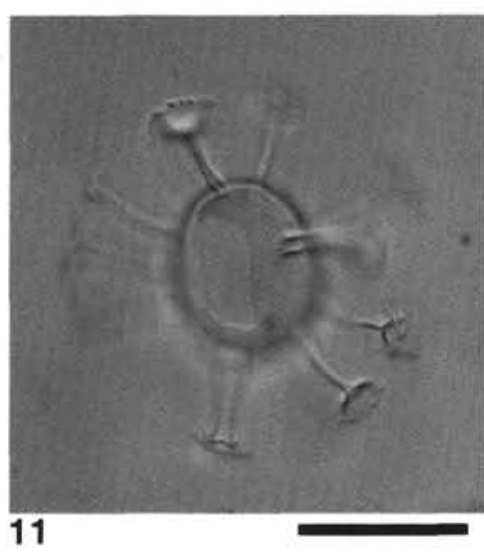

9

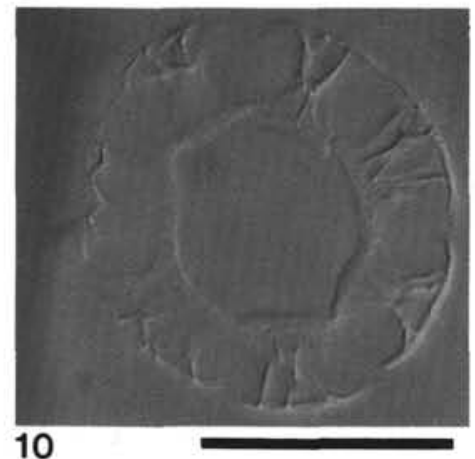

5
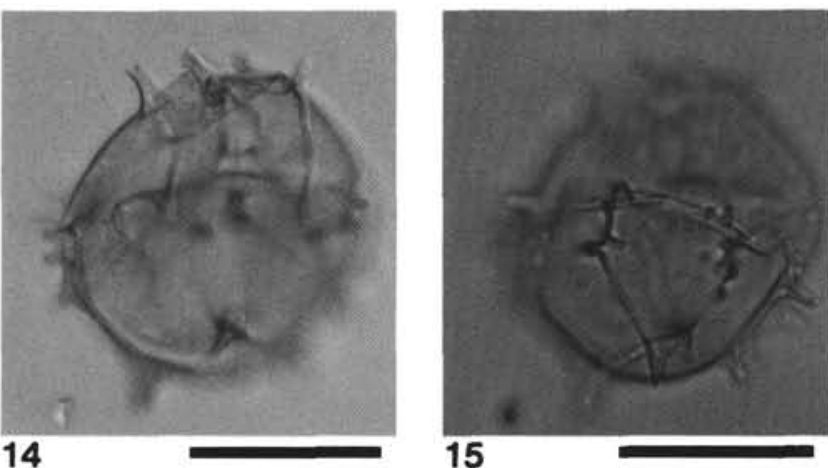

12

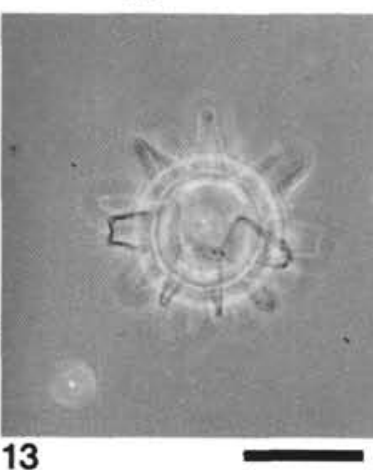

Plate 12. (Scale bars $=30 \mu \mathrm{m} ; \mathrm{Ph}=$ phase, $\mathrm{I}=$ interference, $\mathrm{B}=$ bright field). 1. Impagidinium japonicum; 104-643A-20-6, 30-32 $\mathrm{cm}(\mathrm{Ph})$. 2-4. Impagidinium sp. 3; 104-643A-10-5, 31-33 cm. 2: oblique dorsal, hi. (I). 3: equatorial. (B). 4: oblique dorsal, lo. ( $\mathrm{Ph}$ ). 5-6. Impagidinium sp. 4; 104-643A-24-5, 30-32 cm (Ph). 5: equatorial. 6: dorsal, lo. 7-8. Labyrinthodinium truncatum; 104-643A-11-5, 30-32 cm (I). 9-10. L. cf. truncatum; 104-643A-11-5, 30-32 cm (I). 9: apical, hi. 10: apical, lo. 11. Melitasphaeridium choanophorum; 104-643A-11-5, 30-32 cm (I). 12-13. Litosphaeridium sp. 1; 104-642C-17-1, 69-72 cm (I). 12: equatorial. 13: antapical, lo. 14-15. ?Leptodinium sp. III of Manum 1976; 104-643A-32-1, 30-32 cm (I). Probably a Impagidinium sp. 

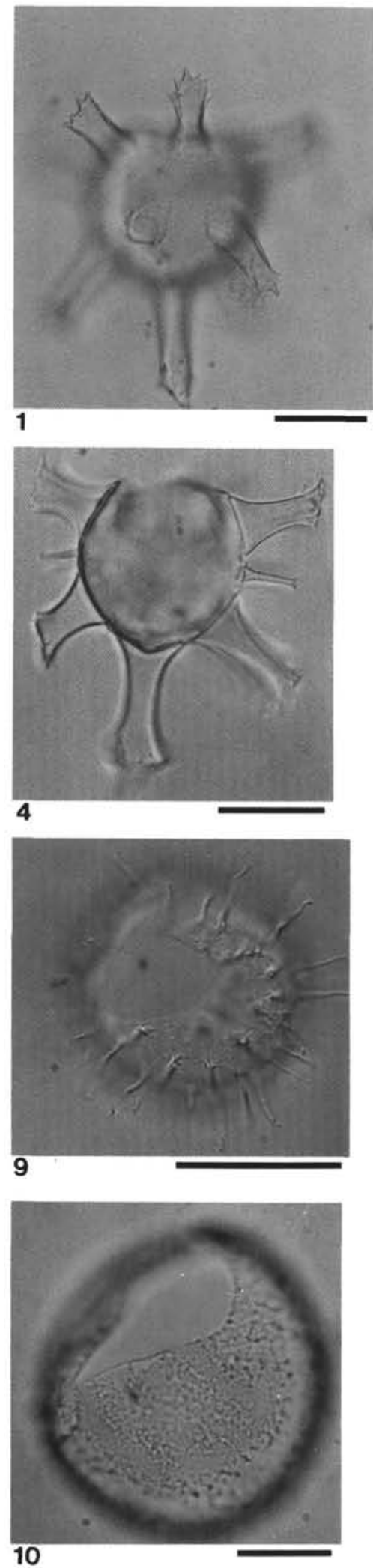
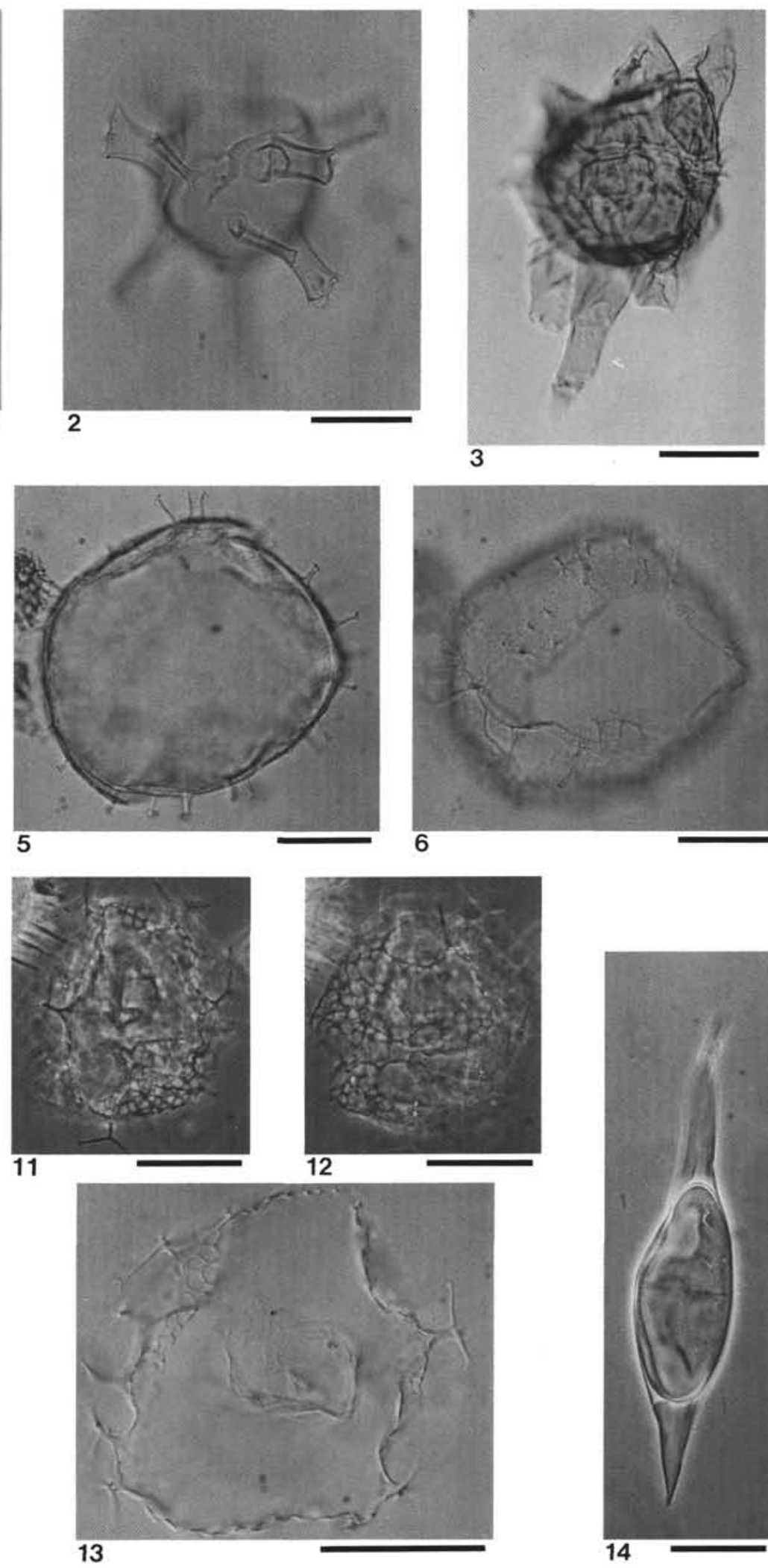

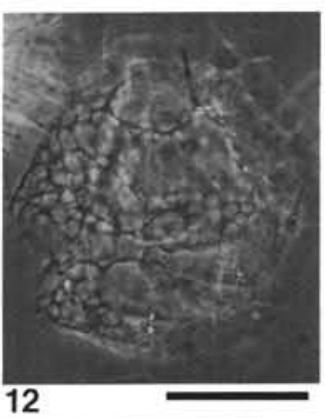

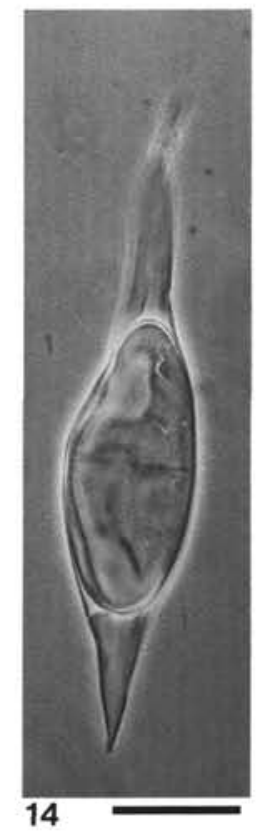

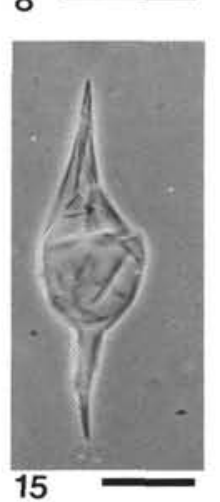

Plate 13. (Scale bars $=30 \mu \mathrm{m} ; \mathrm{Ph}=$ phase, $\mathrm{I}=$ interference, $\mathrm{B}=$ bright field). 1-2. ?Hystrichokolpoma sp. 2; 104-643A-28-7, 30-31 cm (I). The species lacks paracingular processes, but shows affinity to $H$. rigaudiae. 1 : ventral, lo. 2: ventral, hi. 3. Hystrichokolpoma cinctum; 104-643A-45-2, 29-31 cm (B). 4. H. rigaudiae; 104-643A-11-5, 30-32 cm (I). 5-6. Operculodinium sp. 3; 104-643A-10-5, 31-33 cm (I). 5: equatorial. 6: dorsal, hi. 7-8. Palaeocystodinium sp. 1; 104-643A-37-3, 31-33 cm (I). 7: equatorial. 8: ventral, lo. 9. Operculodinium centrocarpum; 104-643A-16-1, 30-32 cm (I). 10. Operculodinium sp. 2; 104-643A-13-6, 31-33 cm (I). 11-13. Hystrichostrogylon sp. 1; 104-643A-16-1, 30-32 cm. 11: oblique dorsal, medium hi. ( $\mathrm{Ph})$ 12: oblique dorsal, hi. $(\mathrm{Ph})$ 13: left lateral, medium hi. (I) 14. Palaeocystodinium sp. 3; 104-643A-29-6, 30-32 cm (Ph). Similar to Svalbardella hampdenensis. 15. Palaeocystodinium sp. A of Costa and Downie 1979; 104-643A-12-5, 31-32 cm (Ph). 

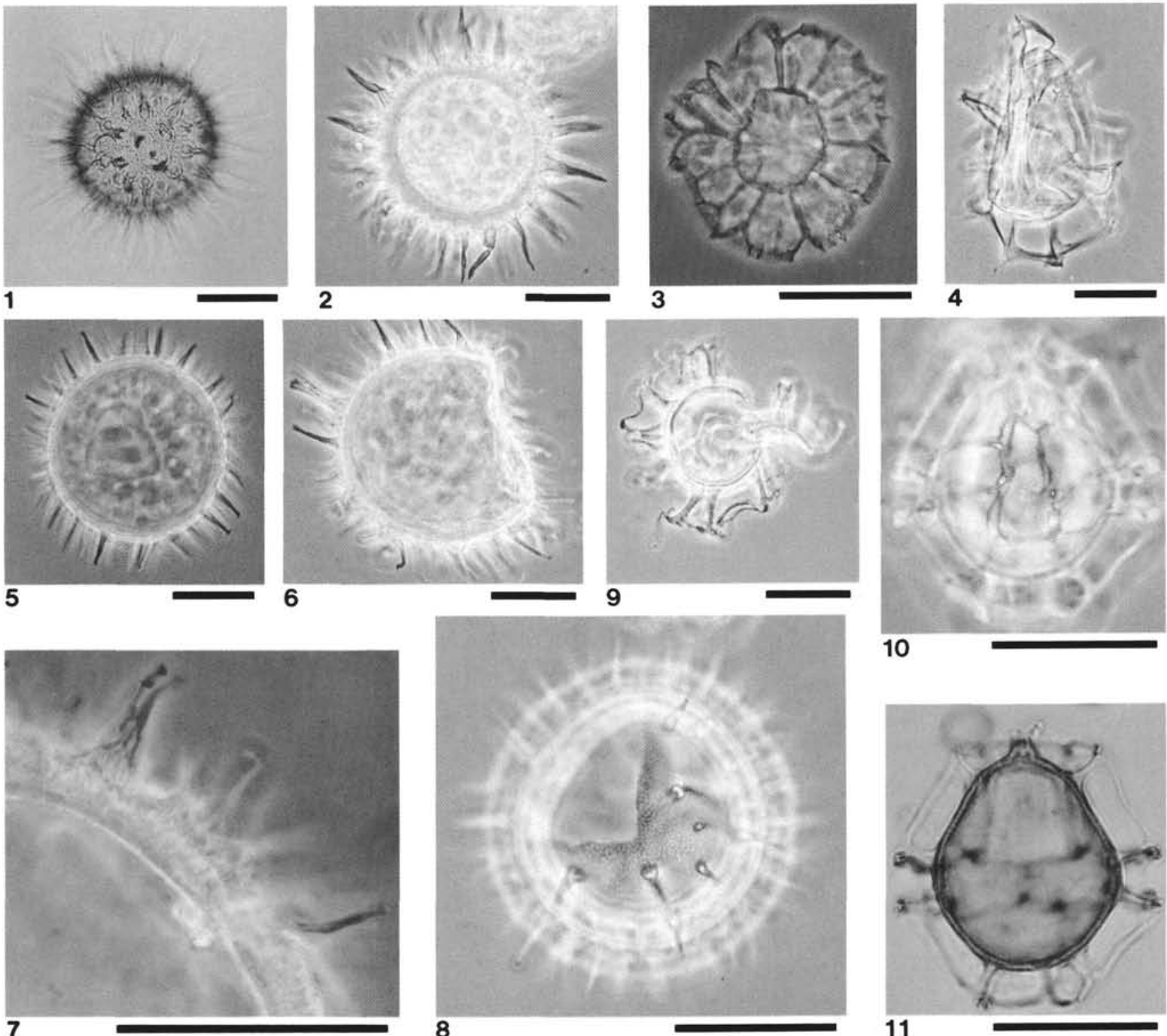

10
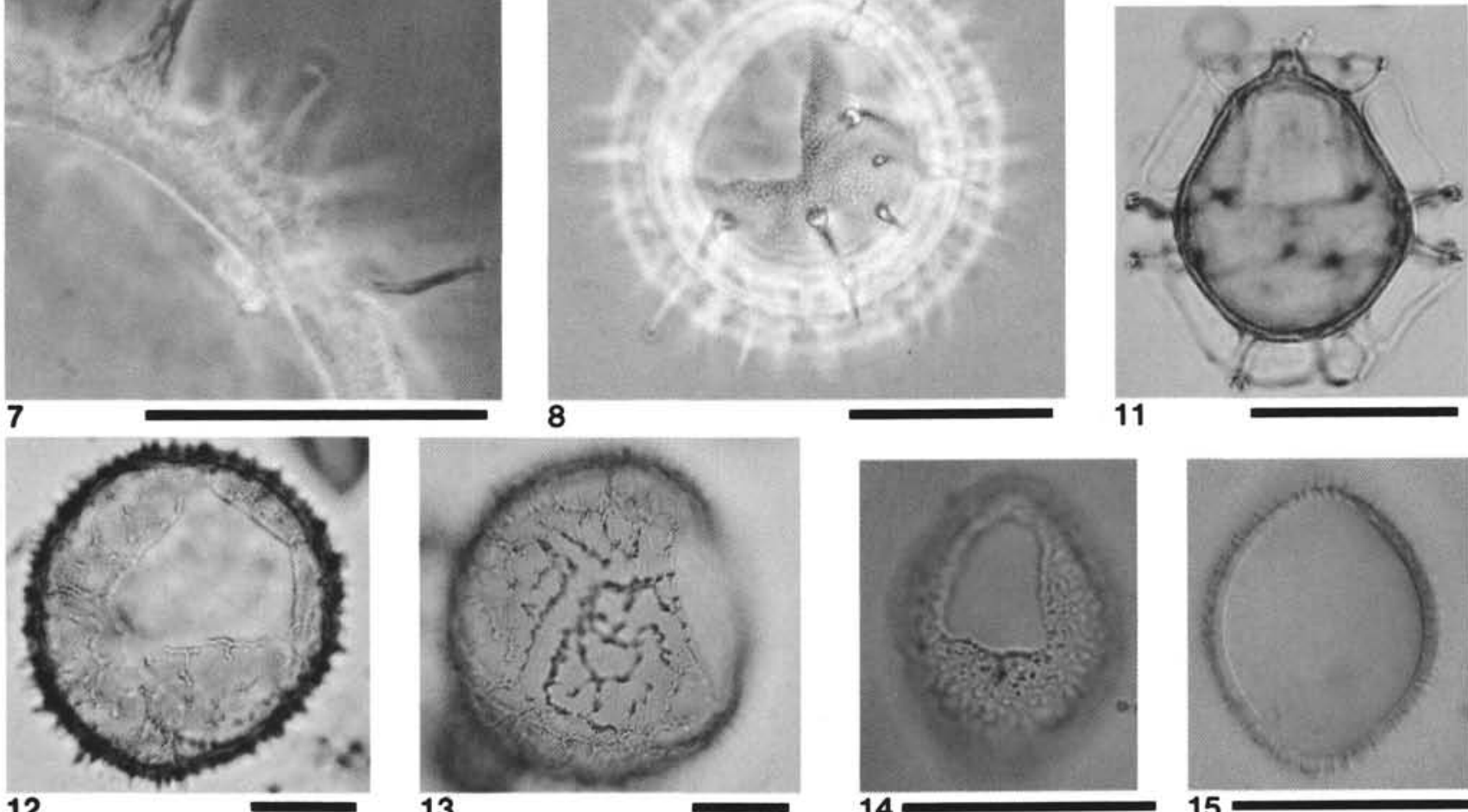

11
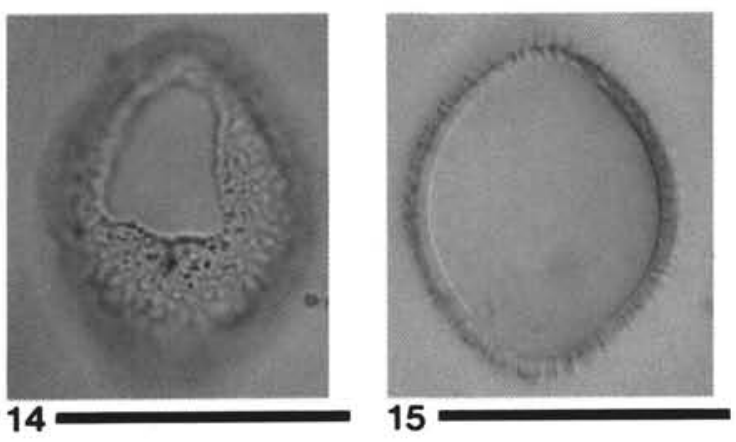

Plate 14. (Scale bars $=30 \mu \mathrm{m} ; \mathrm{Ph}=$ phase, $\mathrm{I}=$ interference, $\mathrm{B}=$ bright field). 1-2. Lingulodinium sp. 1; 104-643A-18-1, 31-33 cm (1:B, 2:Ph). Epicystal archeopyle. 3. Nematosphaeropsis lemniscata; 104-643A-16-1, 30-32 cm (Ph). 4. N. downii; 104-643A-20-6, 30-32 cm (Ph). 5. Operculodinium crassum; 104-643A-9-5, 30-32 cm (Ph). 6. O. crassum; 104-643A-26-5, 30-32 cm (Ph). 7. O. crassum; 104-643A-16-1, 30-32 cm (Ph). Detail showing processes. 8. O. longispinigerum; 104-642C-12-1, 79-80 cm (Ph). 9. Nematosphaeropsis sp. 2; 104-643A-8-6, 48-50 cm. Equatorial $(\mathrm{Ph})$. Rare type with long processes. 10-11. Nematosphaeropsis sp. 2; 104-643A-12-1, 31-33 cm. 10: ventral, hi. (Ph). 11: equatorial. (B). 1213. Operculodinium cf. giganteum; 104-642C-17-1, 69-72 cm (B). 12: ventral, lo. 13: left lateral. 14-15. O. placitum; 104-643A-16-1, 30-32 cm (I). 

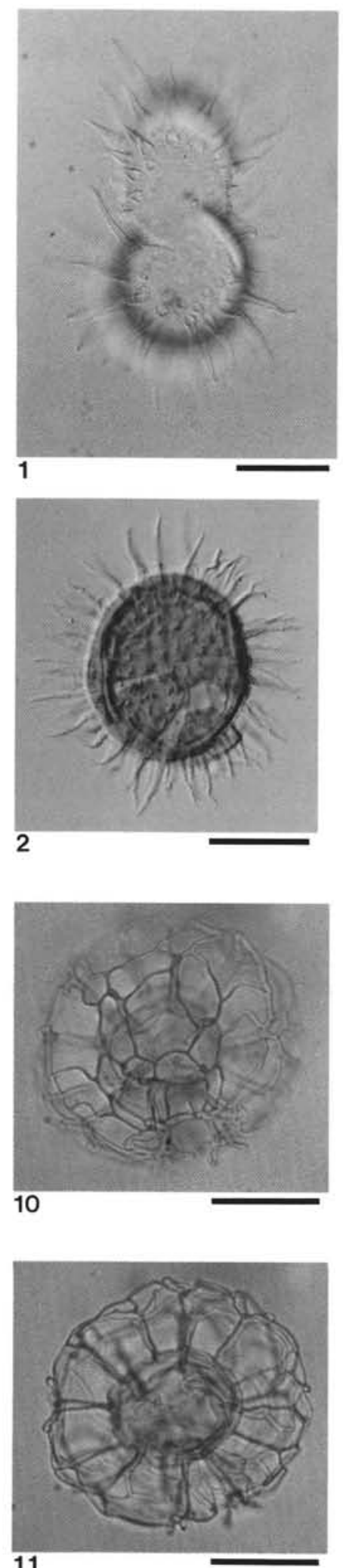

11

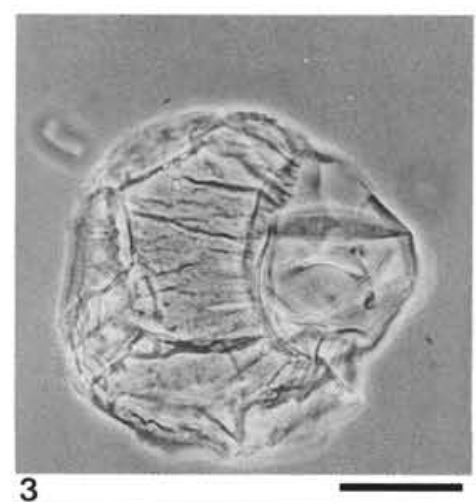

3
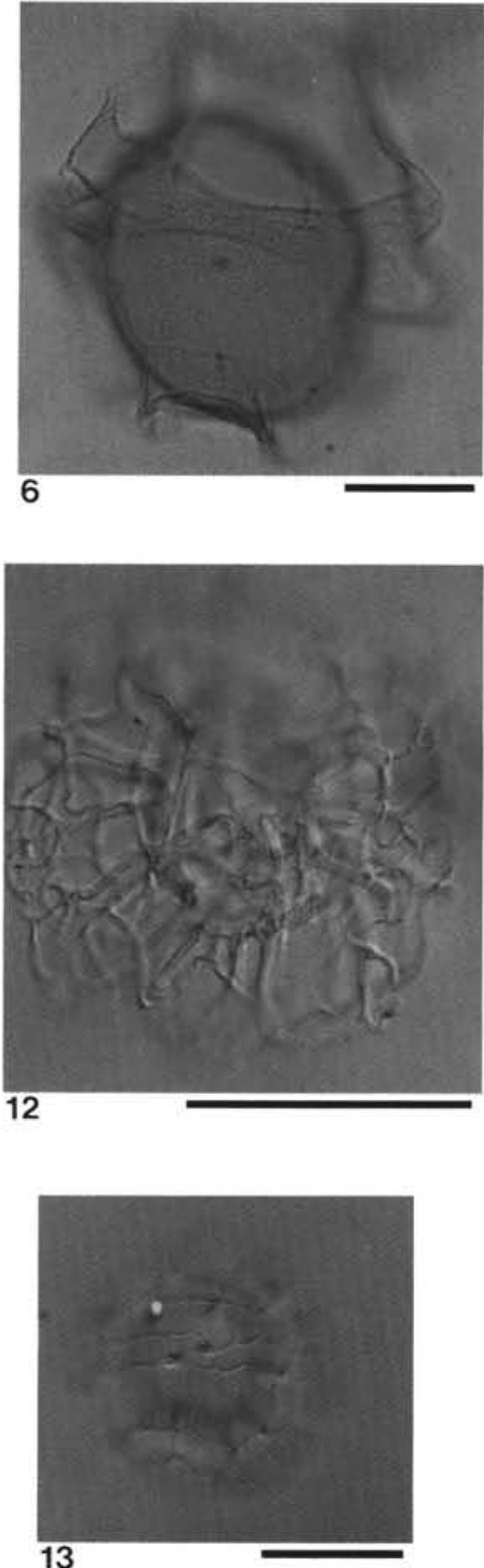
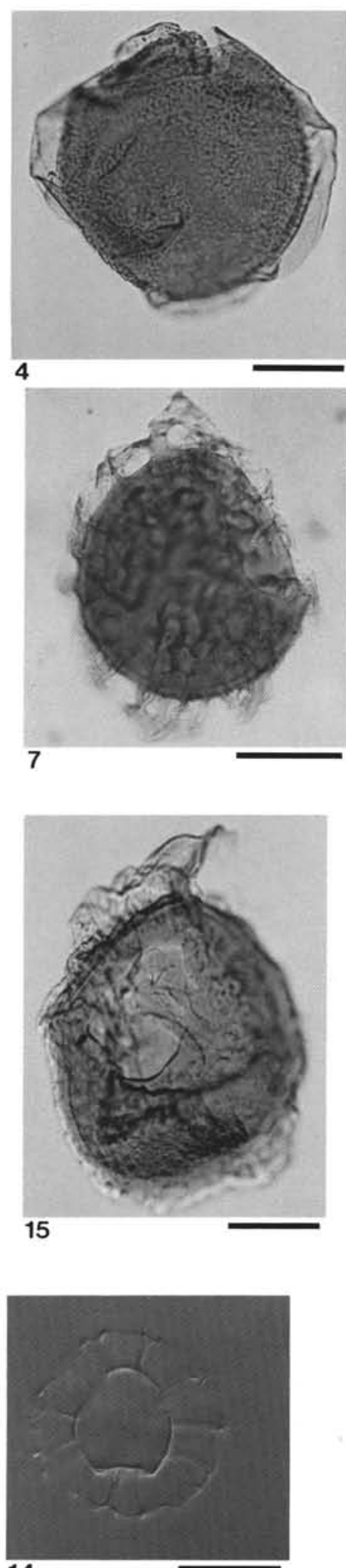

14
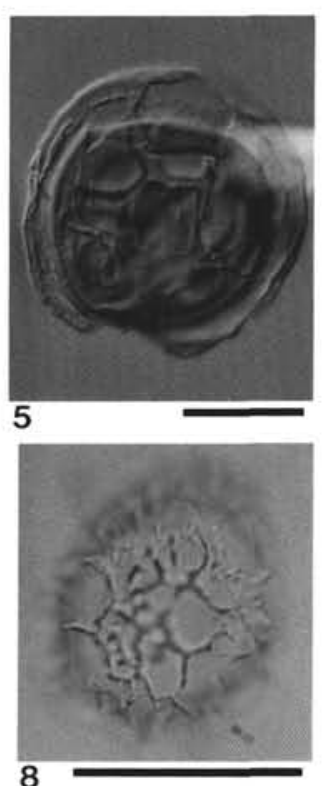

8
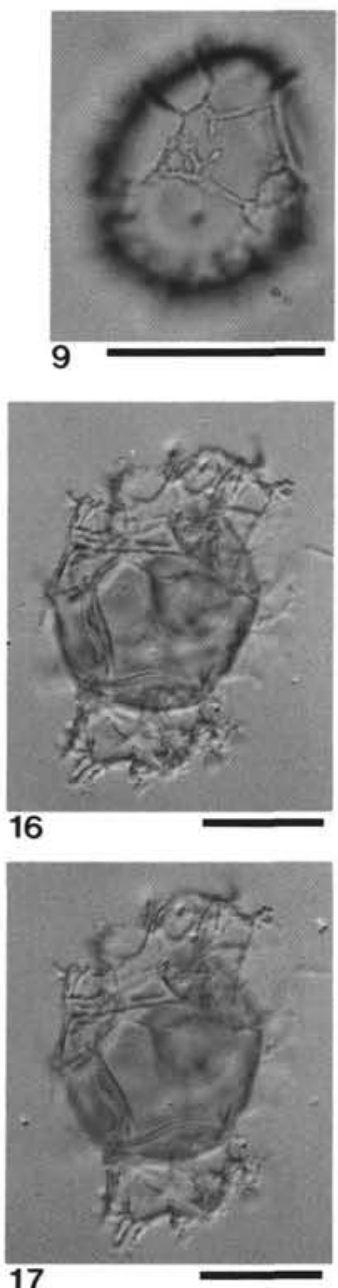

Plate 15. (Scale bars $=30 \mu \mathrm{m} ; \mathrm{Ph}=$ phase, $\mathrm{I}=$ interference, $\mathrm{B}=$ bright field). 1. Lingulodinium machaerophorum; 104-643A-13-6, 31-33 cm (I). 2. L. machaerophorum; 104-643A-45-2, 29-31 cm (I). 3. Lophocysta sulcolimbata; 104-643A-26-5, 30-32 cm (Ph). 4. Pentadinium laticinctum granulatum; 104-643A-45-2, 29-31 cm (I). 5. P. laticinctum laticinctum; 104-643A-49-1, 30-32 cm (B). 6. P. laticinctum imaginatum; 104643A-29-6, 30-32 cm (I). 7. Samlandia chlamydophora; 104-643A-51-4, 30-32 cm (B). 8-9. Corrudinium sp. 1; 104-643A-13-6, 31-33 cm (I). 8: left lateral/ventral, hi. 9: left lateral/ventral, lo. 10-11. Nematosphaeropsis sp. 1; 104-643A-51-4, 30-32 cm (B). 12. Nematosphaeropsis labyrinthea; 104-643A-44-4, 30-32 cm (I). 13-14. N. labyrinthea; 104-643A-15-6, 28-30 cm (I). 15. Samlandia sp. 1; 104-643A-48-1, 90-92 cm (I). Typical is the incomplete ectophragm. 16-17. Rottnestia borussica; 104-643A-60-2, 31-33 cm (I). 

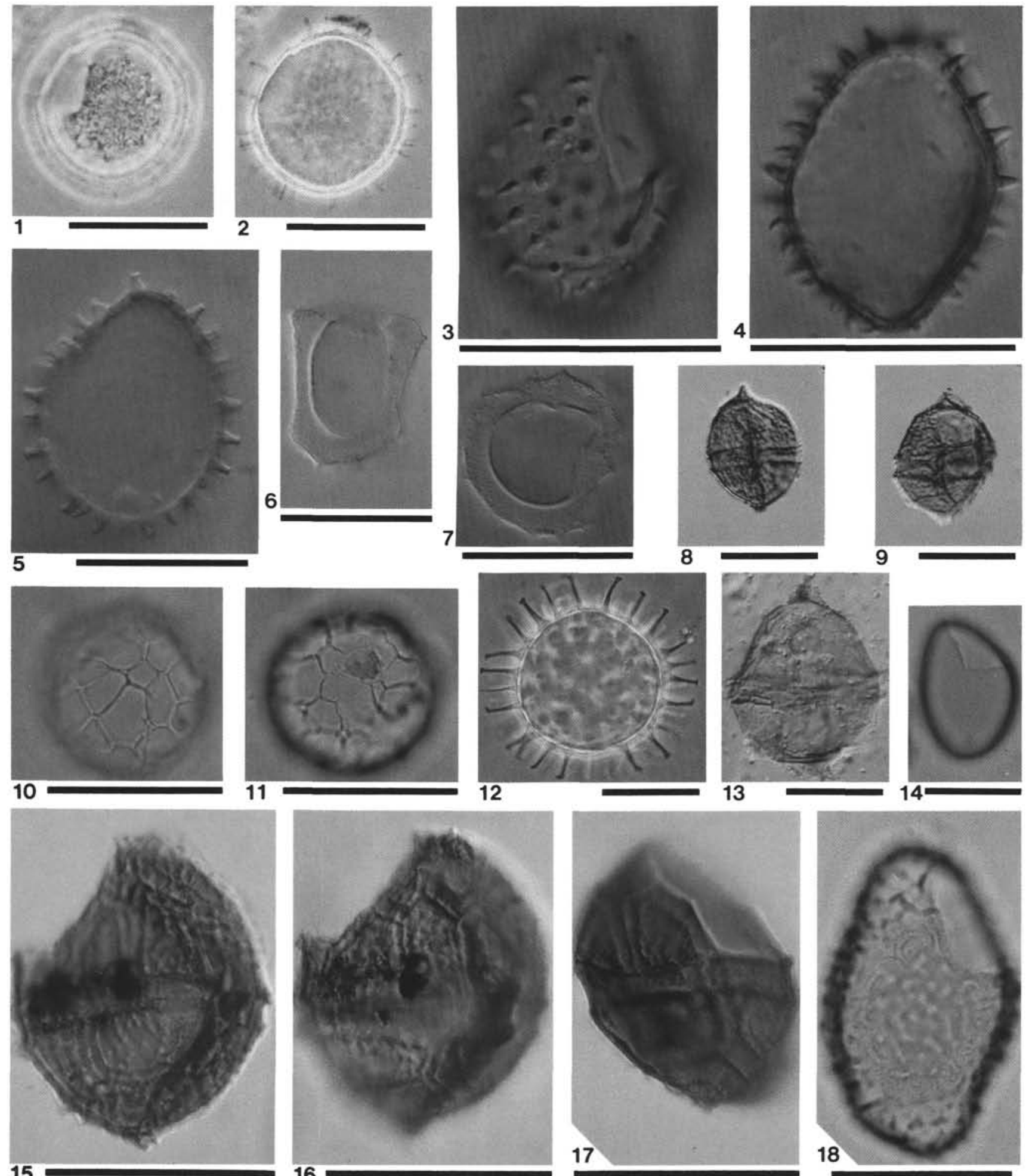

Plate 16. (Scale bars $=30 \mu \mathrm{m} ; \mathrm{Ph}=$ phase, $\mathrm{I}=$ interference, $\mathrm{B}=$ bright field). $1-2$. Operculodinium israelianum; 104-642C-12-1, 78-80 $\mathrm{cm}$ (Ph). 3-4. Operculodinium sp. 1; 104-643A-42-3, 19-21 cm (I). 5. Operculodinium sp. of Piasecki 1980; 104-643A-20-6, 30-32 cm (I). 6. Platycystidia sp. II of Manum 1976; 104-643A-29-6, 30-32 cm (I). 7. Platycystidia sp. II of Manum 1976; 104-643A-11-6, 30-32 cm (I). 8-9. Phthanoperidinium stockmansii; 104-643A-54-1, 30-32 cm (I). 10-11. Problematicum IV of Manum 1976; 104-643A-32-1, 31-32 cm (I). 10: apical, hi. 11: apical, lo. 12. Polysphaeridium cf. subtile; 104-643A-14-5, 32-34 cm (Ph). 13. Phthanoperidinium cf. eocenicum; 104-643A-51-1, 30-32 cm (I). 14. Pyxidiella sp. 1; 104-643A-22-5, 30-32 cm (B). 15-16. Phthanoperidinium geminatum; 104-643A-54-1, 30-32 cm (I). 17. P. geminatum; $104-$ 643A-56-4, 30-32 cm (I). Two plates are lost in the archeopyle, one intercalary and one precingular. 18. ?Pyxidiella simplex; 104-642D-3-2, 80-82 $\mathrm{cm}(\mathrm{I})$. 

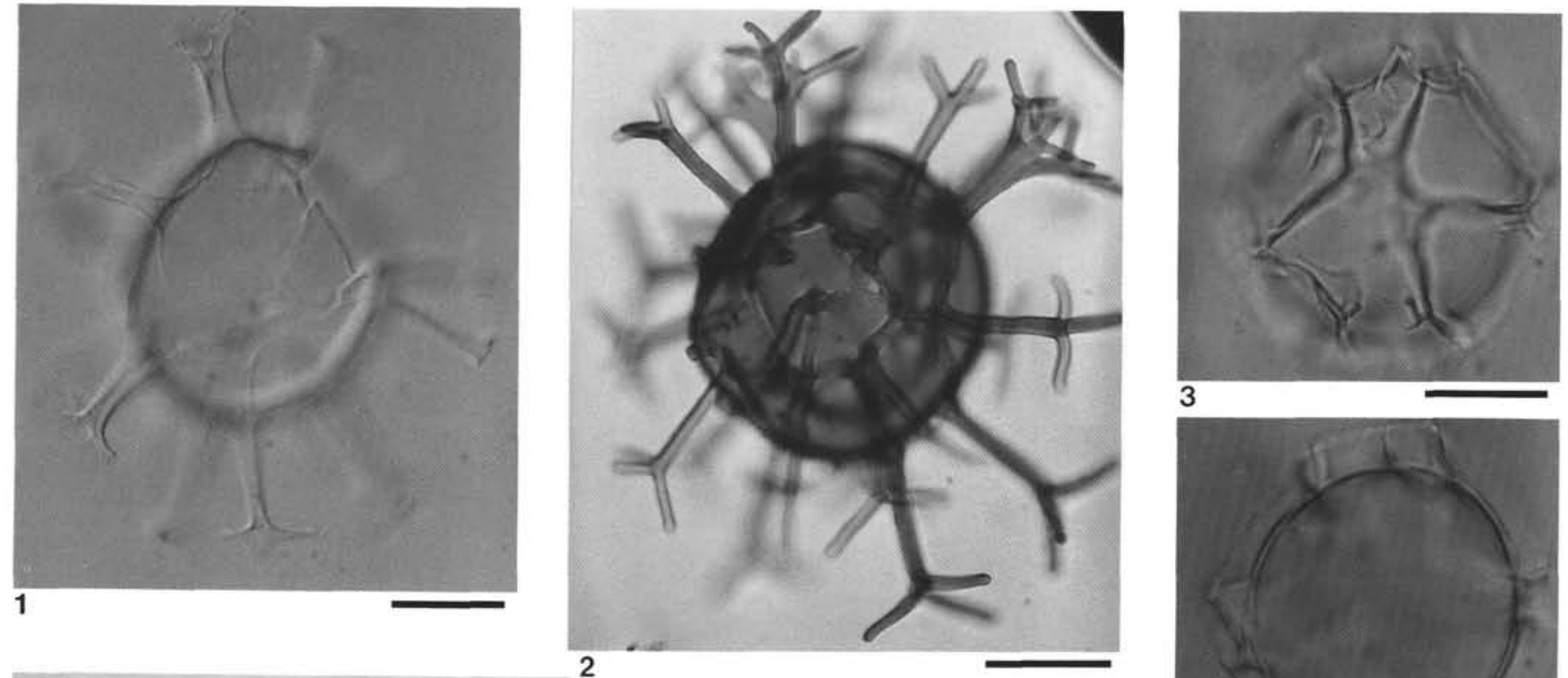

2
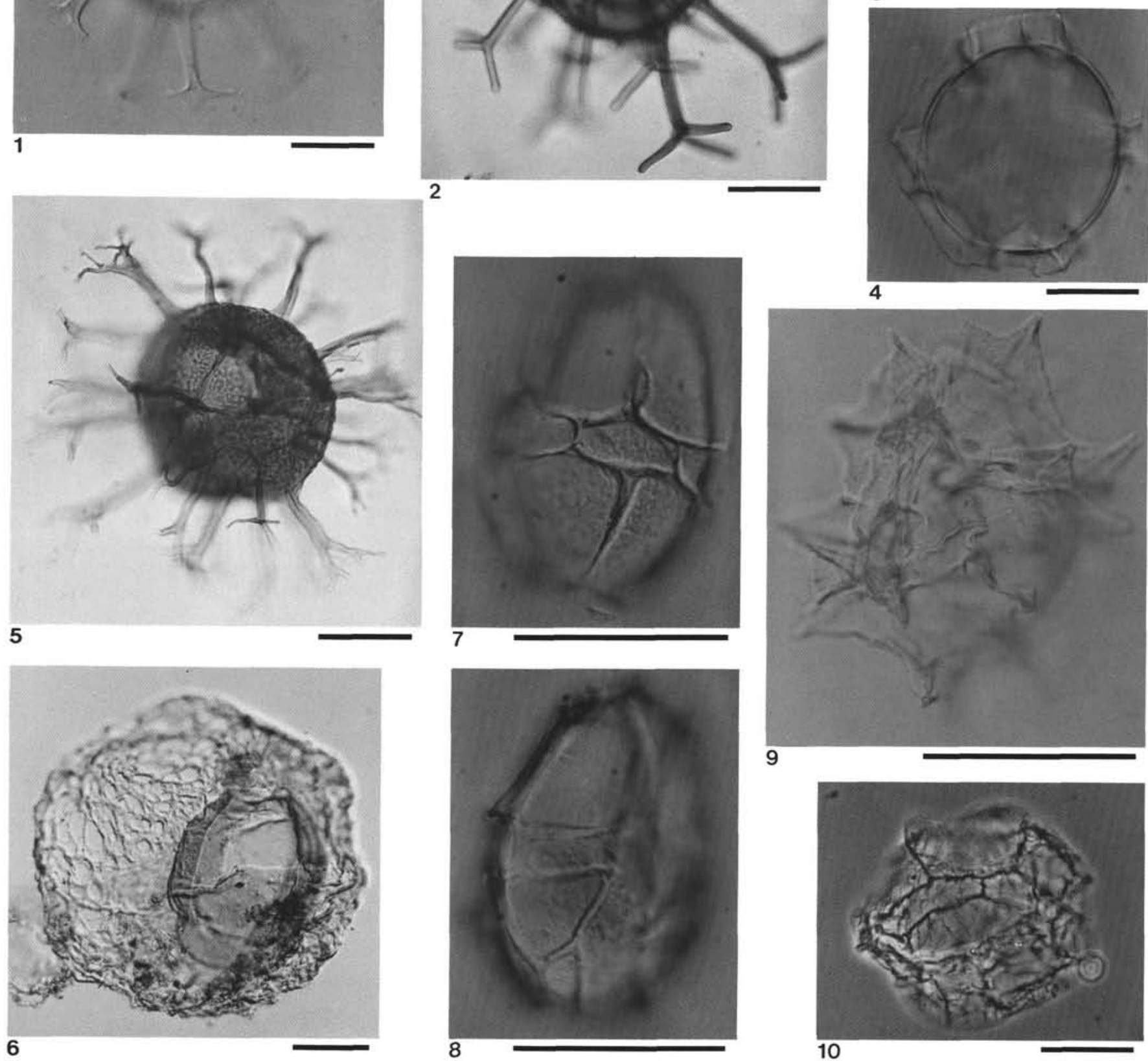

Plate 17. (Scale bars $=30 \mu \mathrm{m} ; \mathrm{Ph}=$ phase, $\mathrm{I}=$ interference, $\mathrm{B}=$ bright field). 1. Spiniferites pseudofurcatus; 104-643A-9-5, 30-32 $\mathrm{cm}$ (I). 2. Spiniferites sp. 2; 104-643A-49-1, 30-32 cm (B). 3-4. Impagidinium patulum; 104-643A-25-6, 30-32 cm (I). 5. Spiniferites sp. 1; 104-643A-49-4, 30-32 cm (B). 6. Thalassiphorafenestrata; 104-643A-51-3, 30-32 cm (I). 7-8. Impagidinium sp. 1; 104-643A-44-6, 30-32 cm (I). 9. Impagidinium aculeatum; 104-643A-44-6, 30-32 cm (I). 10. I. pallidum; 104-643A-27-5, 31-33 cm (Ph). 


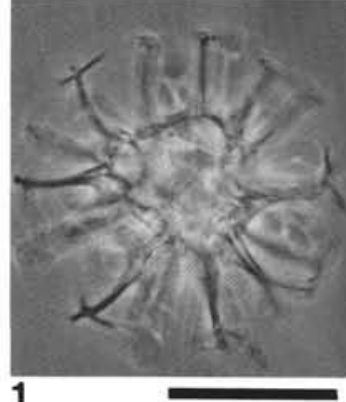

1
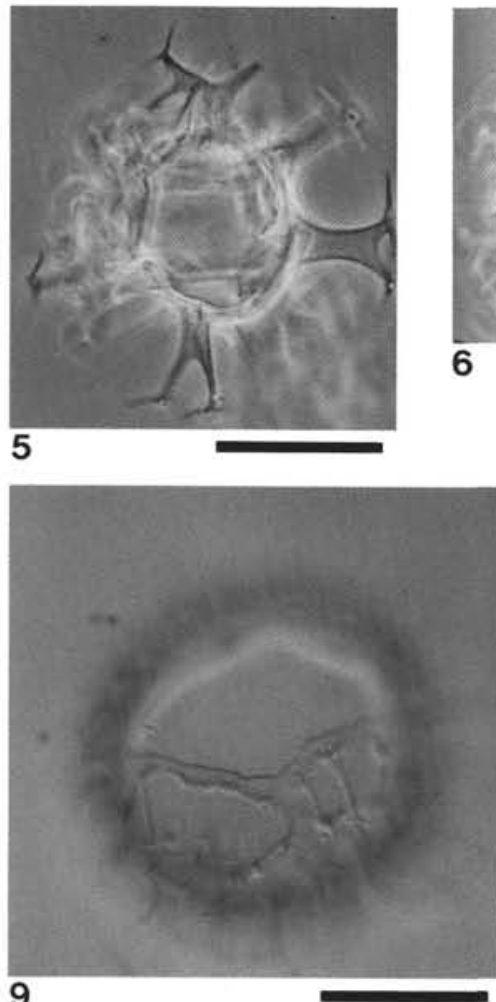

9

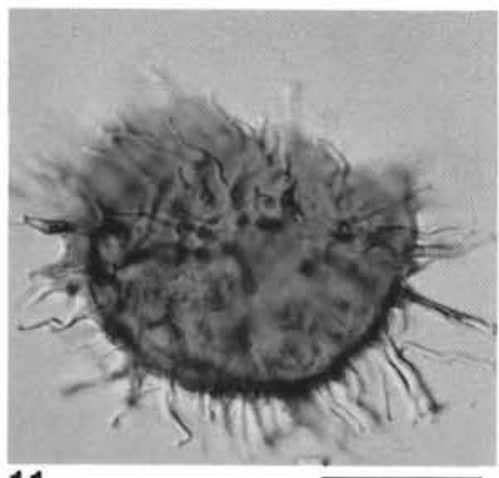

11

6

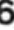

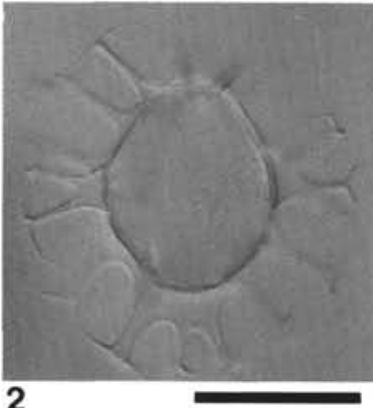
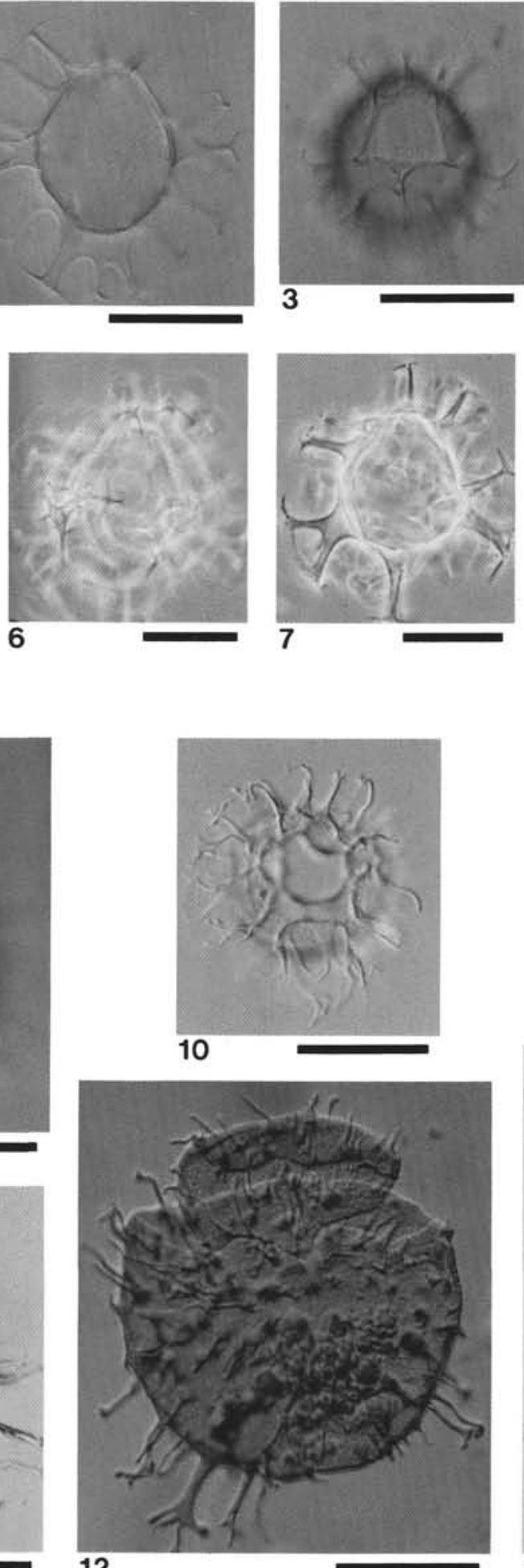

12

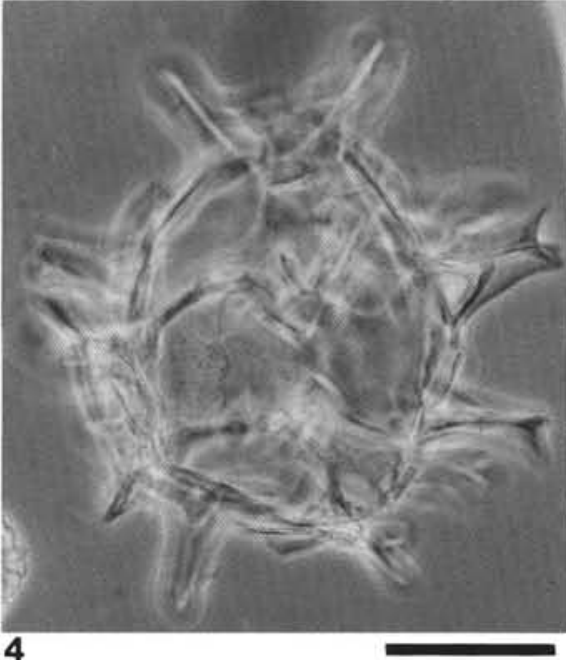

4
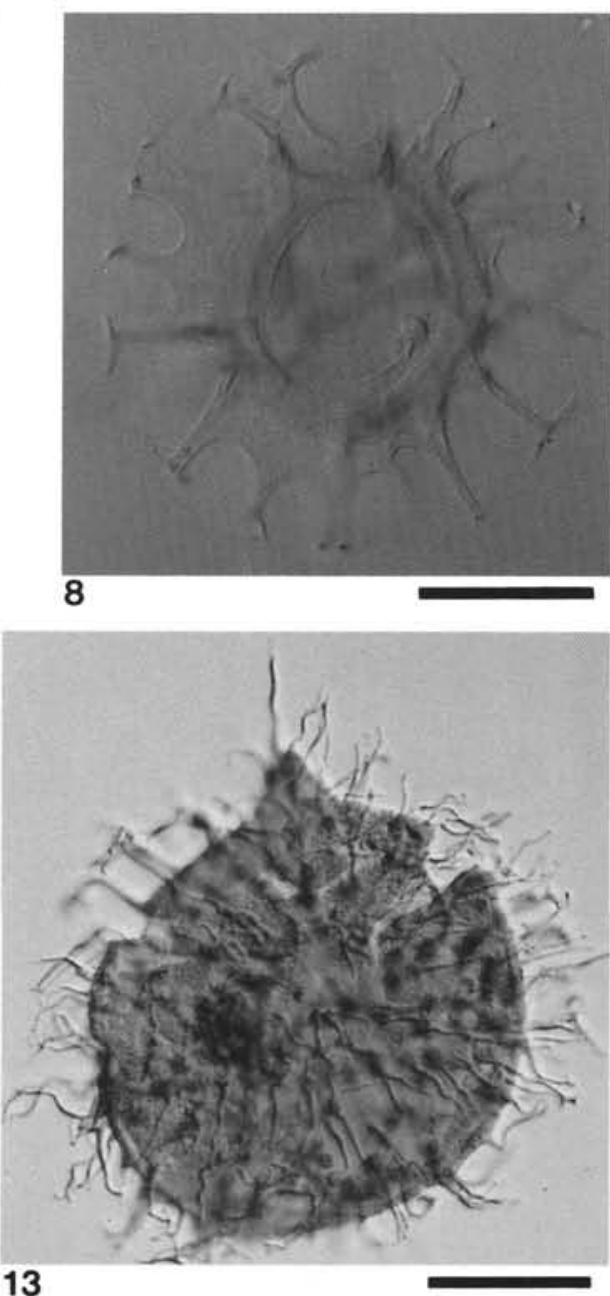

Plate 18. (Scale bars $=30 \mu \mathrm{m}, \mathrm{Ph}=$ phase, $\mathrm{I}=$ interference, $\mathrm{B}=$ bright field). 1 . Spiniferites ramosus-group; 104-643A-11-5, 30-32 $\mathrm{cm}$ ( $\mathrm{Ph}$ ). 2. S. ramosus-group; 104-643A-11-5, 30-32 cm (I). 3. S. ramosus-group; 104-643A-20-6, 30-32 cm (I). 4. S. ramosus-group; 104-643A-18-1, 31$33 \mathrm{~cm}(\mathrm{Ph})$. 5-7. Spiniferites sp. 4; 104-643A-11-5, 30-32 cm (Ph). 5: equatorial. 6: left lateral, hi. 7: equatorial. 8. Spiniferites ramosus-group; 104643A-8-6, 48-50 cm (I). 9. Systematophora placacantha; 104-643A-15-6, 28-30 cm (I). 10. S. placacantha; 104-643A-41-1, 18-20 cm (I). $11-13$. Systematophora sp. 1; 104-643A-45-4, 29-31 cm (I). Note the great variability, ring-structures at the process-bases more or less distinct. 


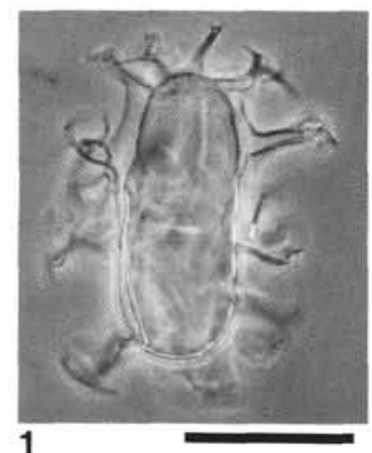

1
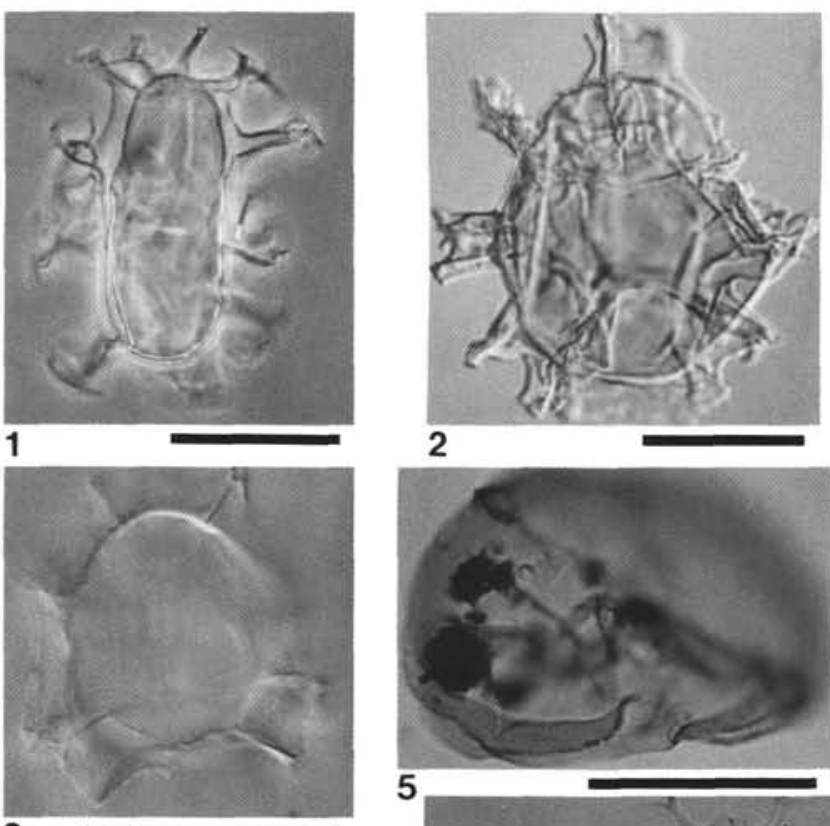

3
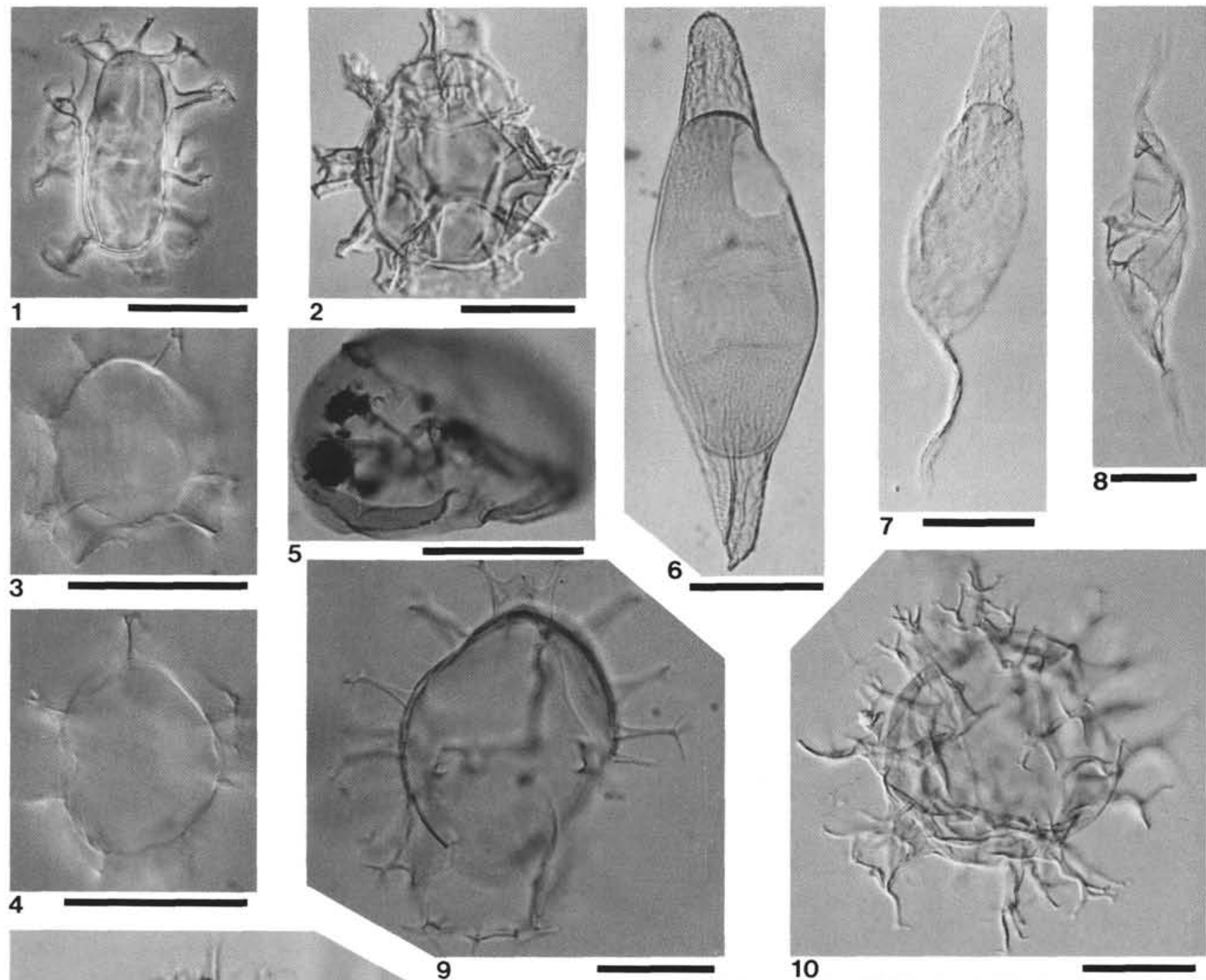

7
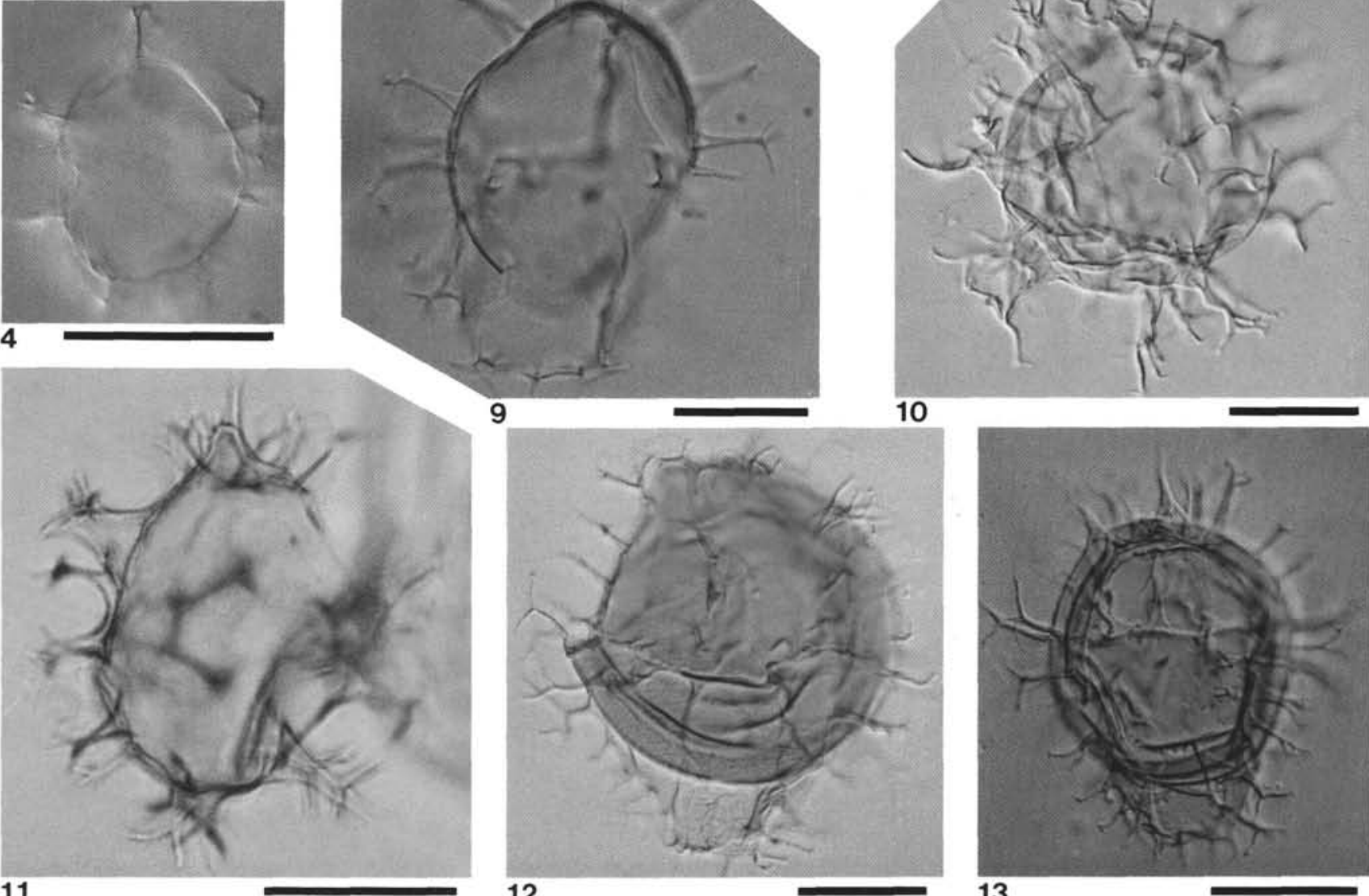

9
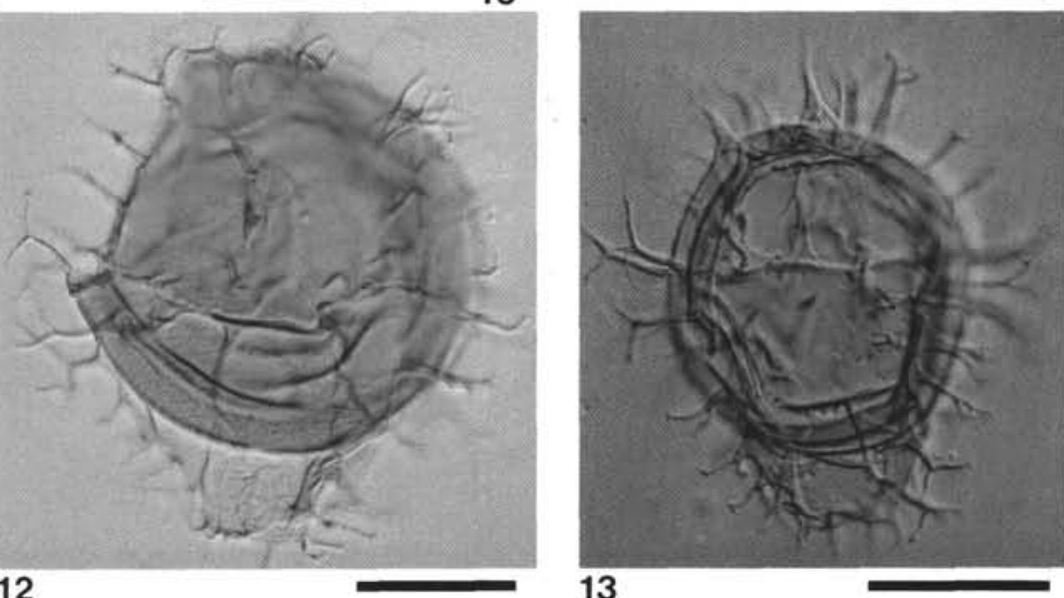

Plate 19. (Scale bars $=30 \mu \mathrm{m}, \mathrm{Ph}=$ phase, $\mathrm{I}=$ interference, $\mathrm{B}=$ bright field). 1. Spiniferites elongatus; 104-643A-8-6, 48-50 $\mathrm{cm}(\mathrm{Ph}) . \quad 2$. Pterodinium cf. premnos; 104-643A-55-5, $30-32 \mathrm{~cm}$ (I). 3-4. P. cingulatum cingulatum; 104-643A-11-5, $30-32 \mathrm{~cm}$ (I). 5. Selenopemphix nephroides; 104-643A-12-5, 30-32 cm (I). 6. Svalbardella cooksoniae; 104-643A-50-1, 30-32 cm (B). 7. Palaeocystodinium sp. 2; 104-643A-39-1, $30-32 \mathrm{~cm}(\mathrm{Ph})$. All specimens badly preserved. 8. Palaeocystodinium golzowense; 104-643A-25-2, 30-32 cm (Ph). 9. Spiniferites cf. mirabilis; $104-$ 643A-11-5, 30-32 cm (I). Note the apical "crown". 10. S. hyperacanthus; 104-643A-44-4, 30-32 cm (I). 11. S. bentorii; 104-643A-8-6, 48-50 cm (B). 12-13. Spiniferites sp. 3; 104-643A-45-2, 29-31 cm (I) resembles $S$. mirabilis, but have more processes participating in the antapical fringe. 


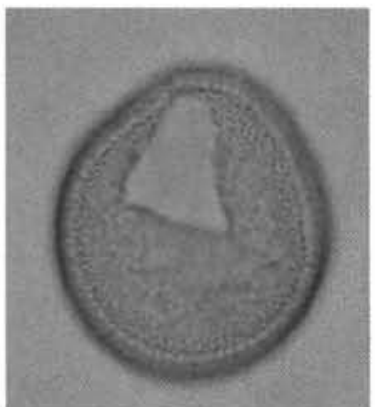

1
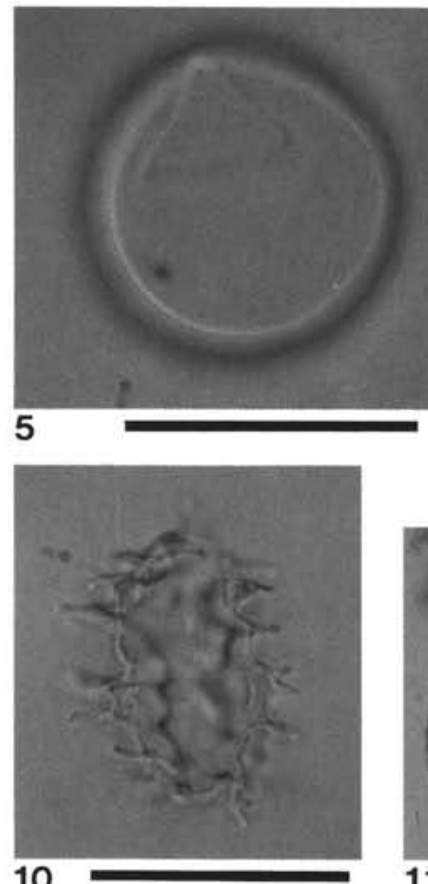

10

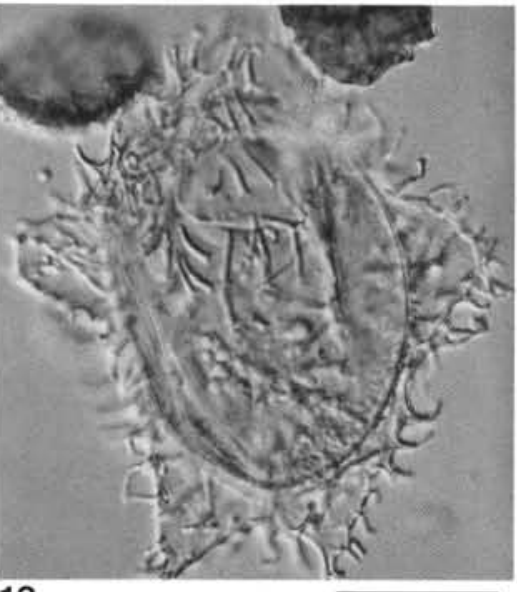

13

6

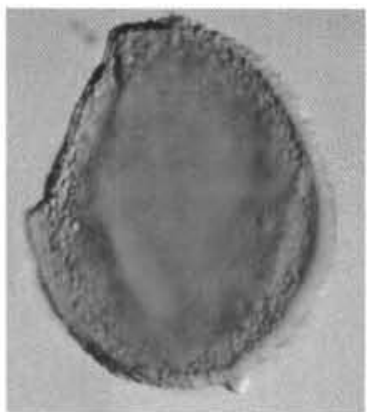

2

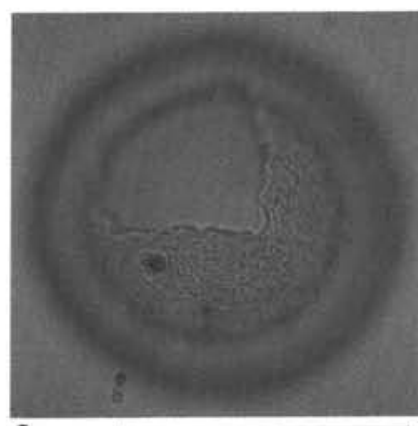

3
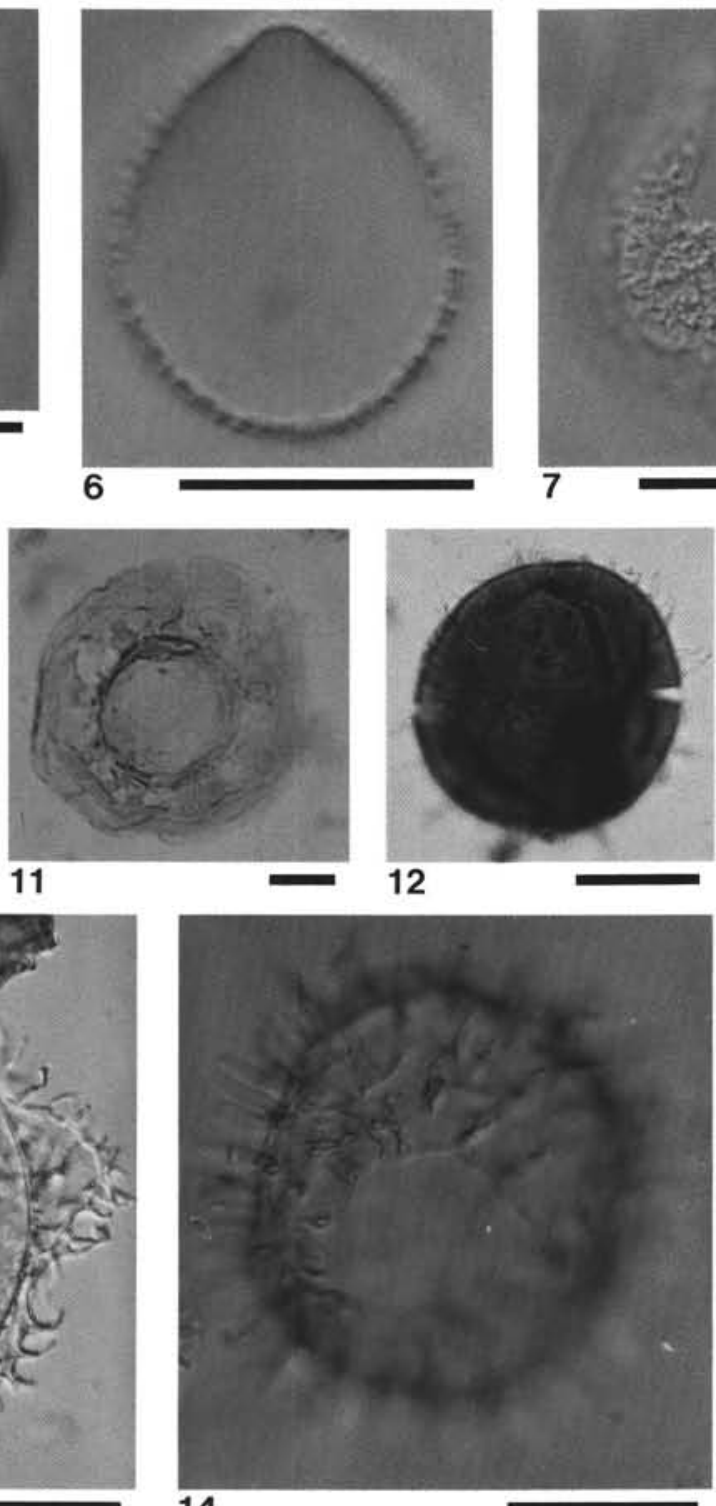

14

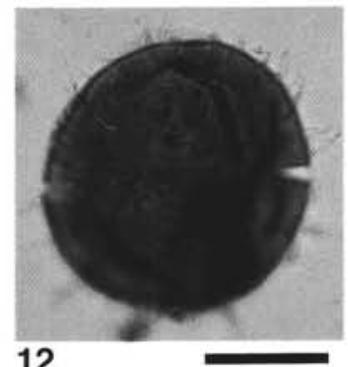

12

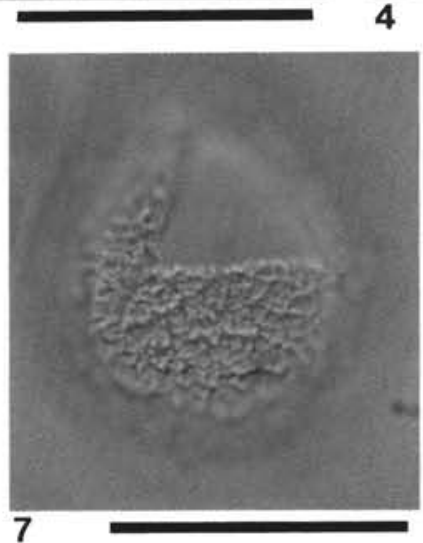

4
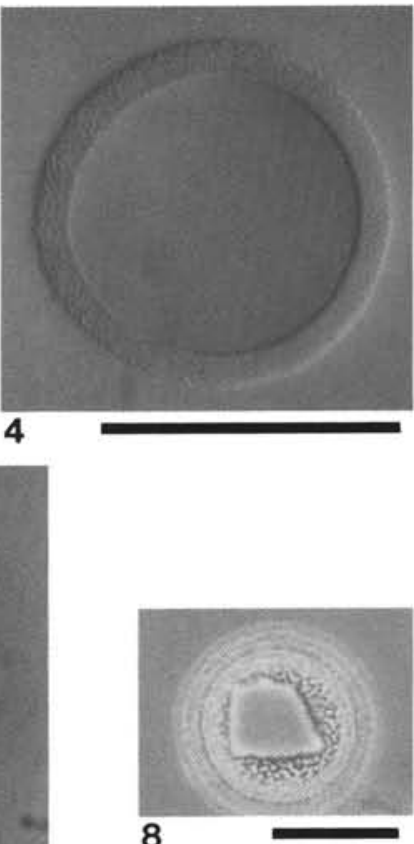

8

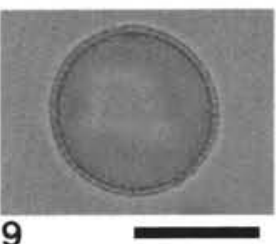

9

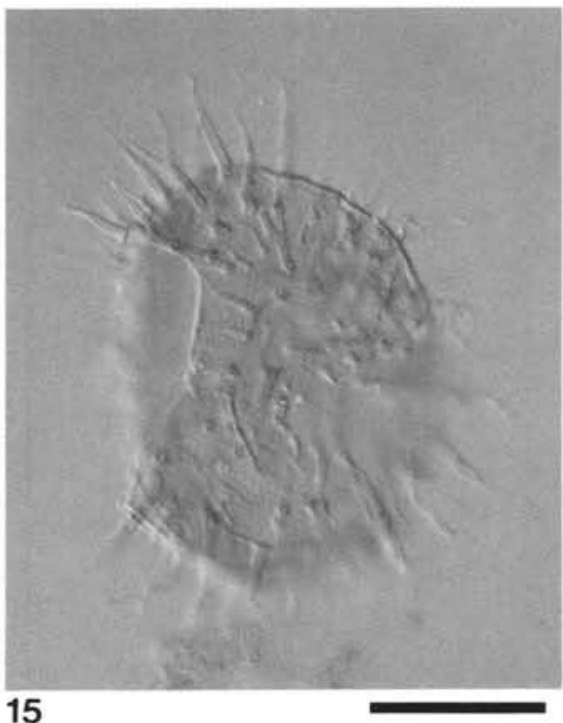

Plate 20. (Scale bars $=30 \mu \mathrm{m} ; \mathrm{Ph}=$ phase, $\mathrm{I}=$ interference, $\mathrm{B}=$ bright field). 1. Tectatodinium psilatum; 104-643A-11-5, 30-32 $\mathrm{cm}$ (I). Scabrate type. 2. Tectatodinium sp. 1; 104-643A-55-5, 30-32 cm (B). 3-4. Tectatodinium sp. 2; 104-643A-8-6, 48-50 cm (I). 3: dorsal, hi. 4: equatorial. 5. Tectatodinium psilatum; 104-643A-22-5, 30-32 cm (I). Psilate type. 6-7. Tectatodinium sp. 4; 104-643A-11-5, 30-32 cm (I). 6: equatorial. 7: dorsal, hi. 8-9. Tectatodinium sp. 3; 104-643A-15-6, 28-30 cm. 8: dorsal, hi. (Ph) 9: equatorial (I). 10. Tanyosphaeridium sp. I of Manum 1976; 104-643A-33-1, 53-54 cm (I). 11. Tuberculodinium vancampoae; 104-643A-29-1, 30-32 cm (I). 12. ?Sumatradinium sp. C of Powell 1986a; 104-642D-6-5, 80-82 cm (B). Specimen from unoxidized sample. 13. Wetzeliella articulata; 104-643A-60-2, 31-33 cm (B). 14. ?Sumatradinium sp. D of Powell 1986a; 104-643A-11-5, 30-32 cm (I). 15. ?Sumatradinium sp. C of Powell 1986a; 104-643A-28-7, 30-31 cm (I). Specimen from oxidized sample. 


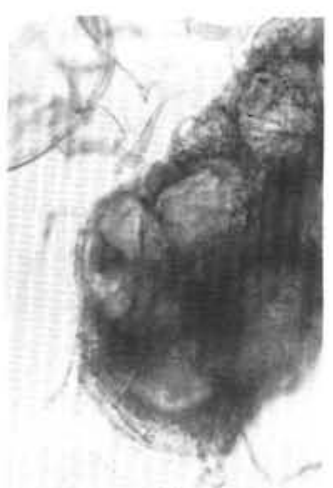

1

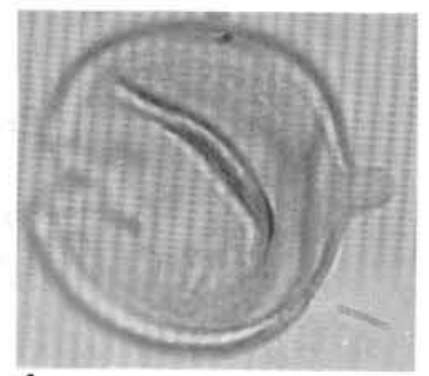

4

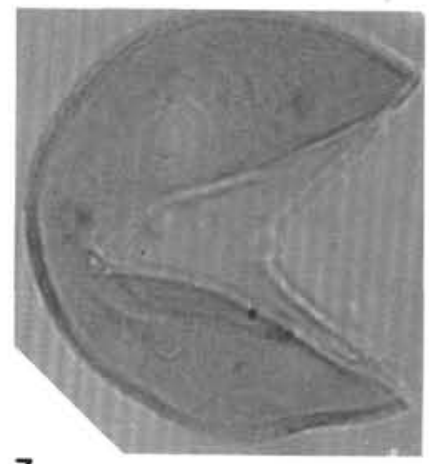

7

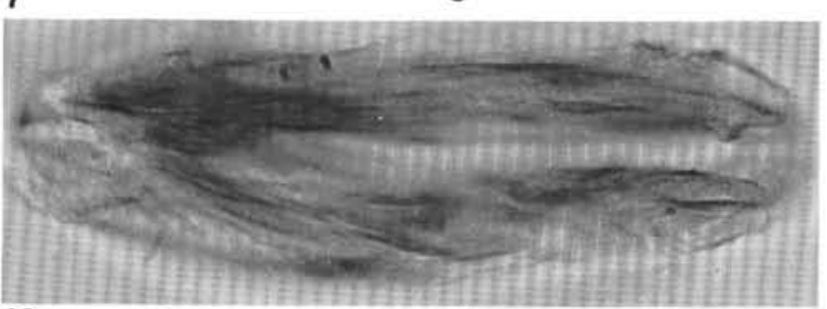

10

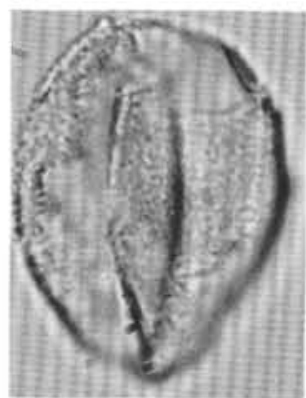

12

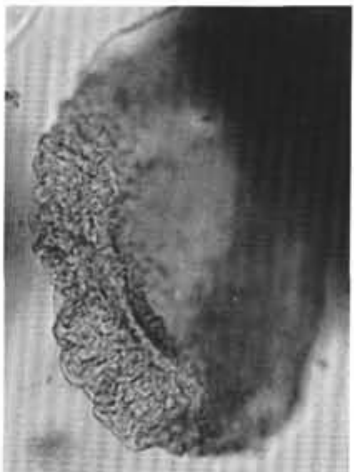

2

5

8
13

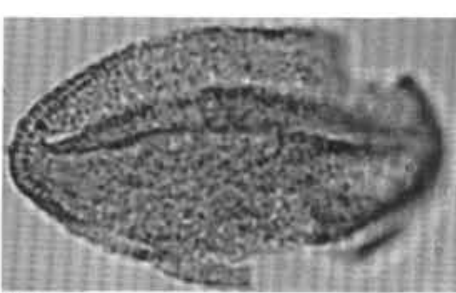

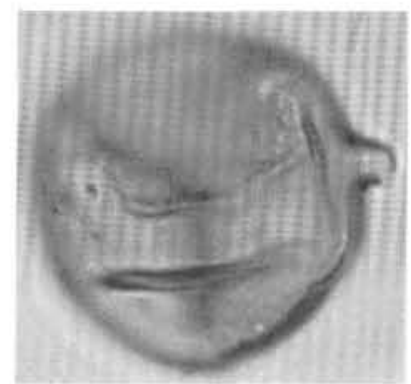
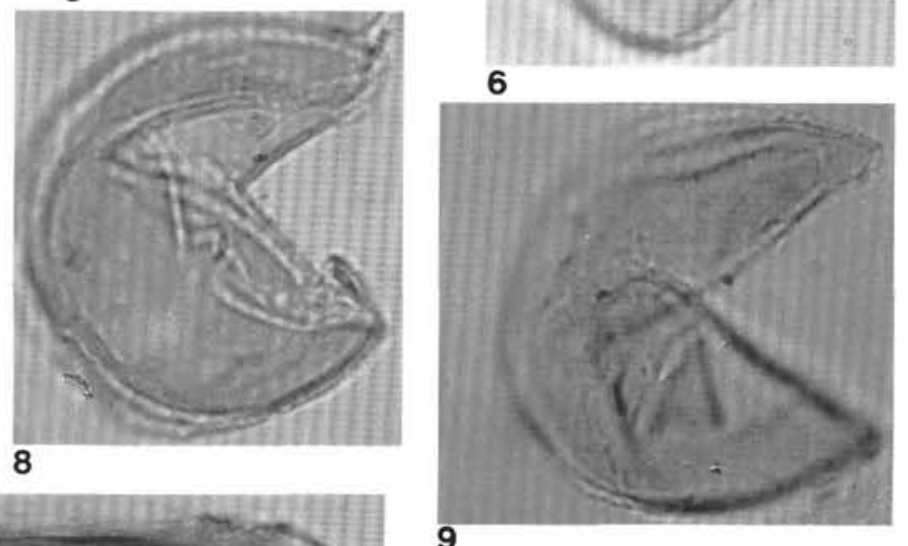

9

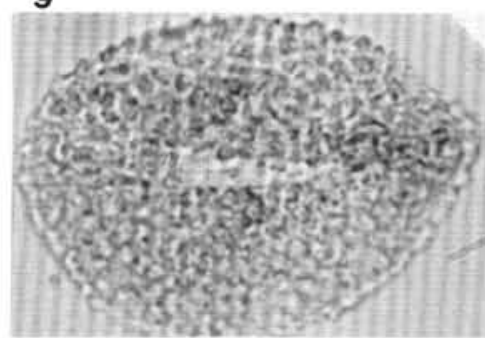

11
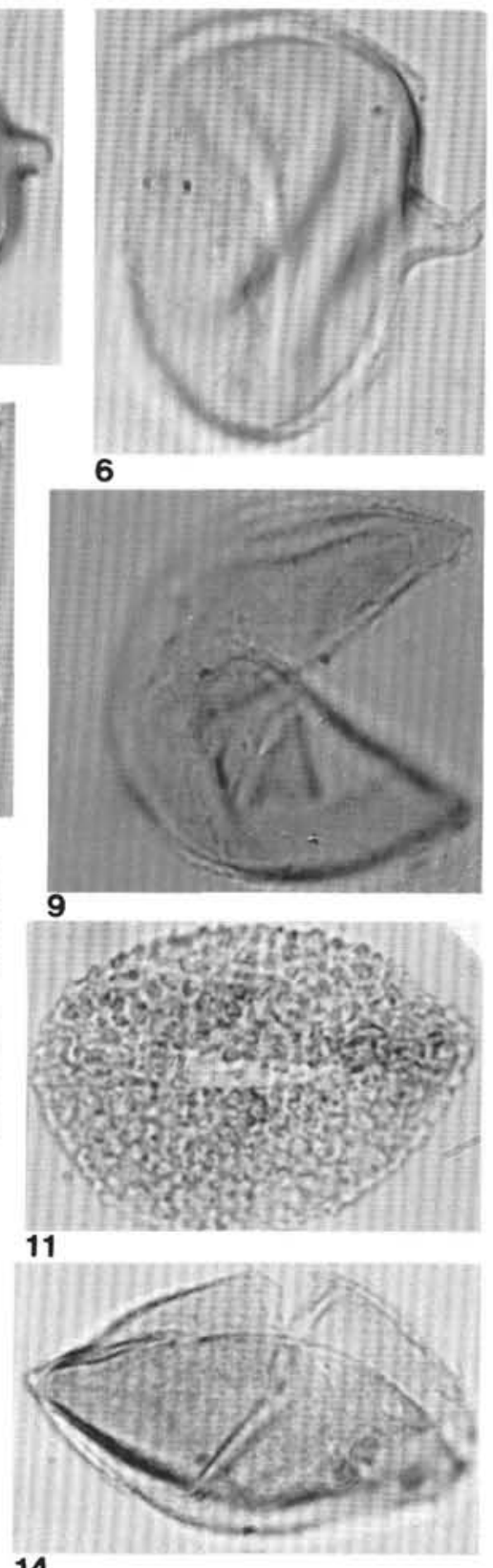

6

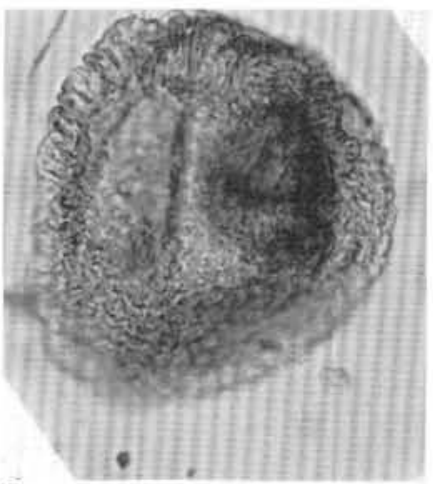

3

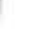




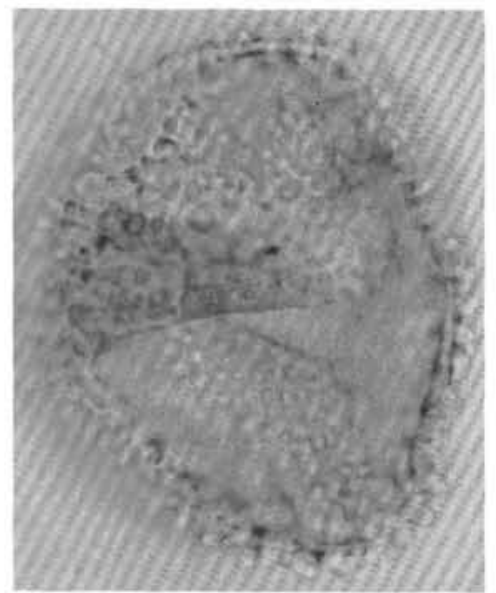

1

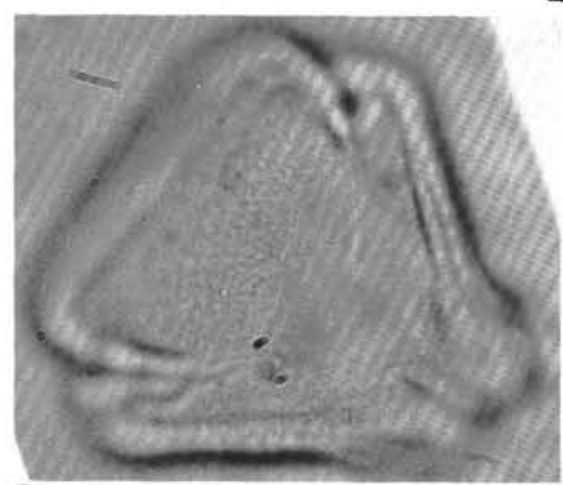

6

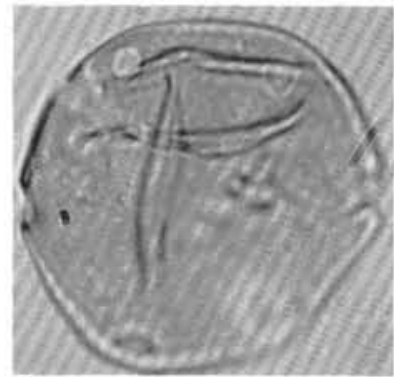

9

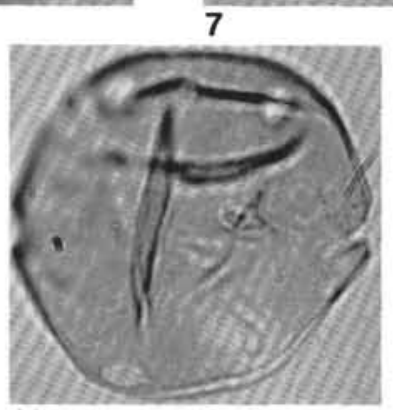

10

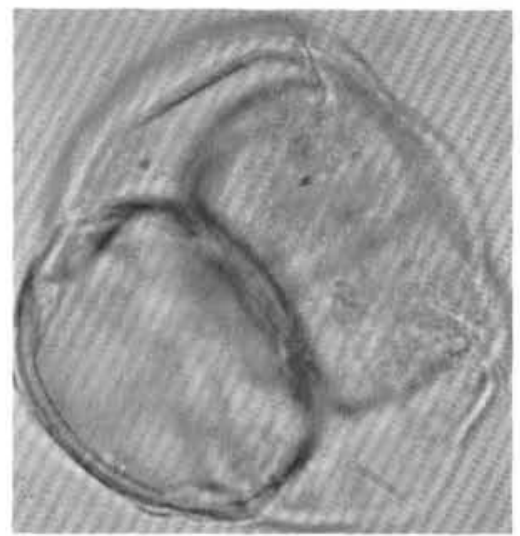

13

2
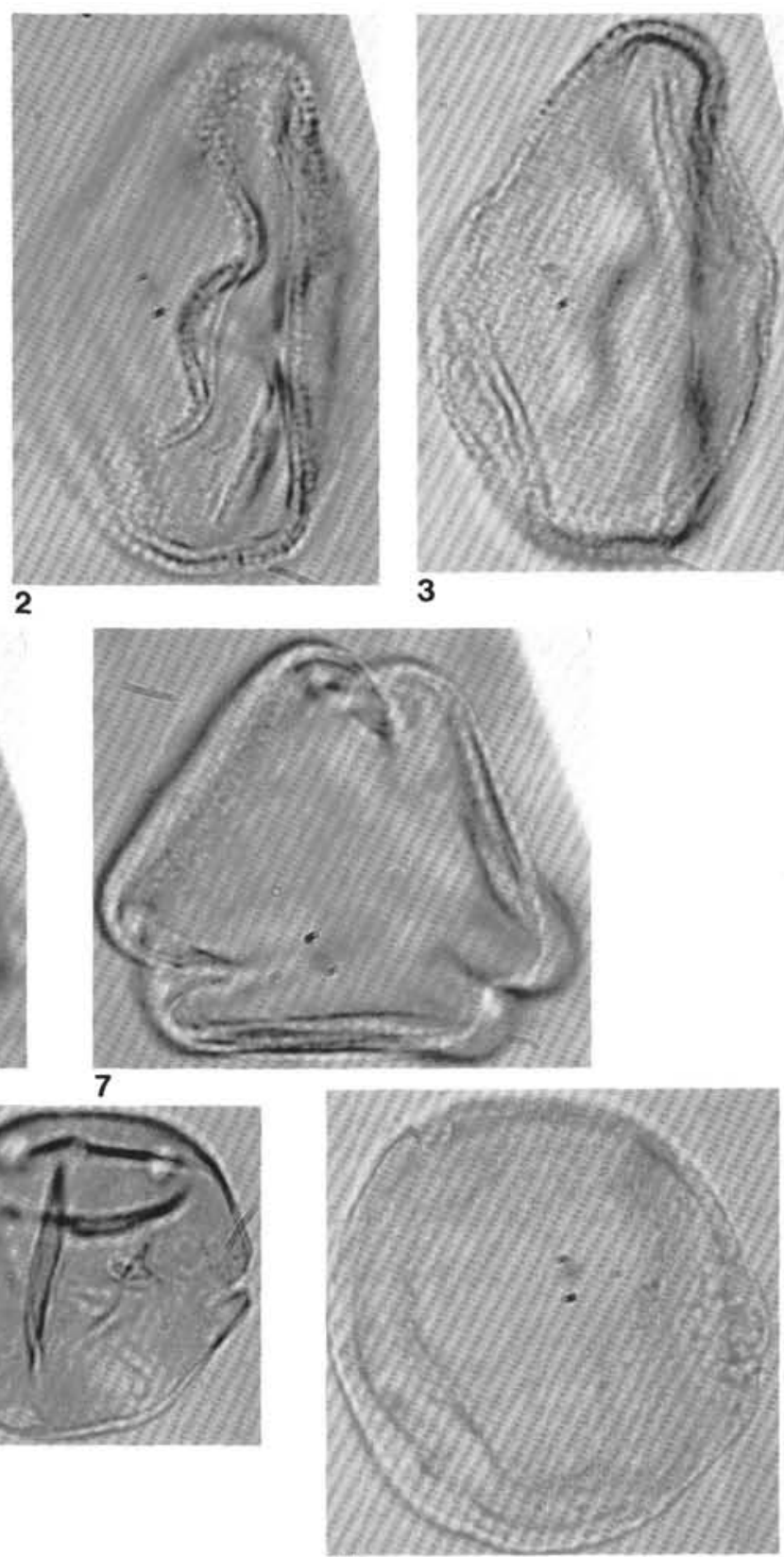

3

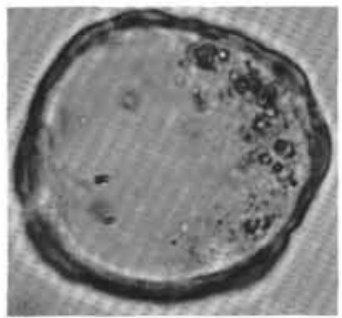

4

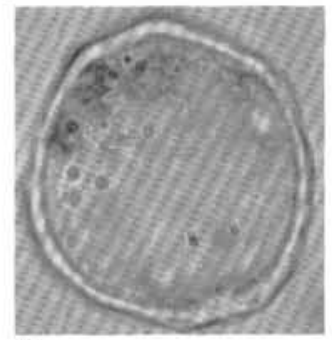

5

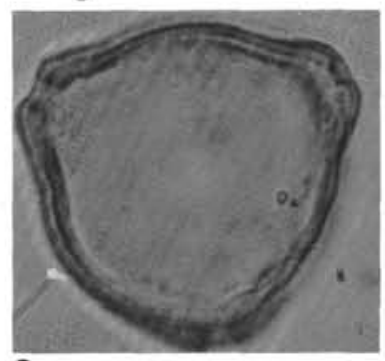

8

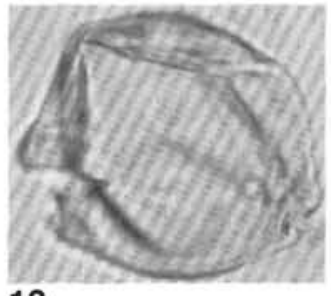

12

$25 \mu \mathrm{m}$
11

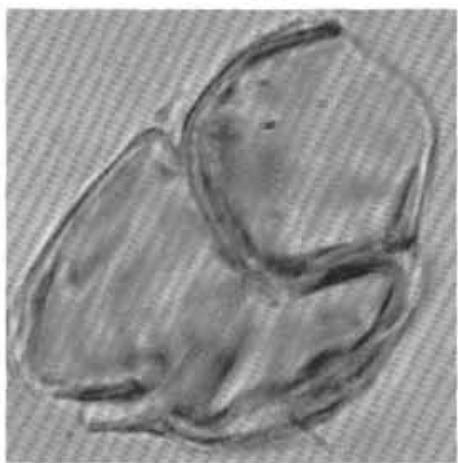

14

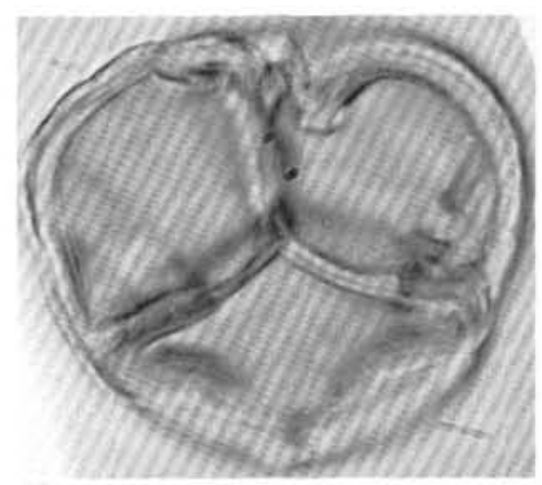

15

Plate 22. (Scale bars $=25 \mu \mathrm{m}$ ) 1. BACULATE TRILETE; 104-643A-25-3, $30 \mathrm{~cm}$. 2-3. RETICULATE MONOCOLPATE; 104-643A-22-1, 30 $\mathrm{cm}$. 4-5. RUGULATE MULTIPORATES; 104-642C-20-7, $67 \mathrm{~cm}$. 6-7. LARGE TRICOLPATE; 104-642C-21-6, 84 cm. 8. THICKPORE TRIPORATE; 104-642B-13-5, $68 \mathrm{~cm}$. 9-10. RUGULATE MULTIPORATE; 104-642C-20-7, $67 \mathrm{~cm}$. 11. THINPORE TRIPORATE; 104-643A-15-5, $28 \mathrm{~cm}$. 12. SMALLPORE TRIPORATE; 104-643A-44-7, $40 \mathrm{~cm}$. 13-15. TETRADS; 104-643A-24-5, $30 \mathrm{~cm}$. 


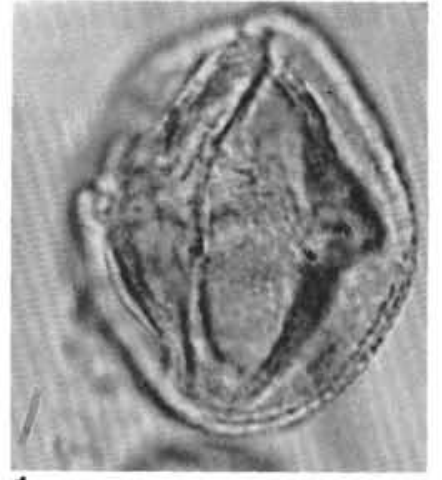

1

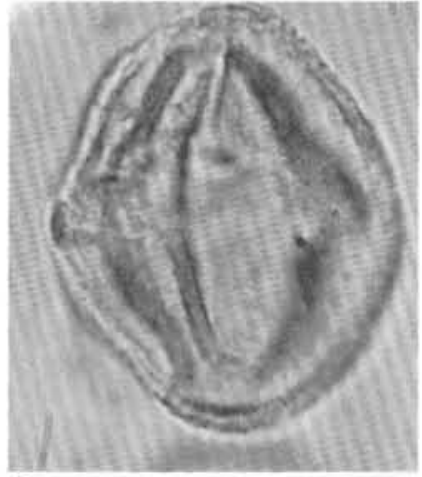

2

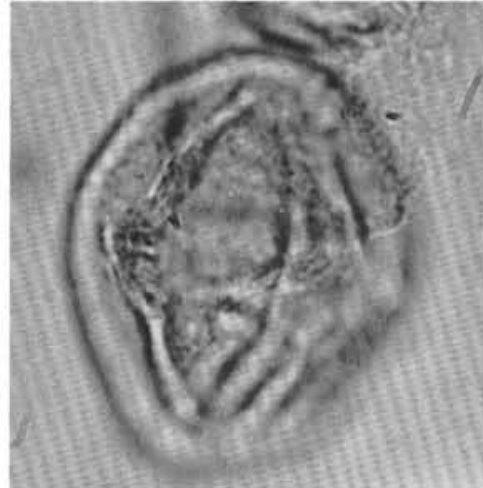

3

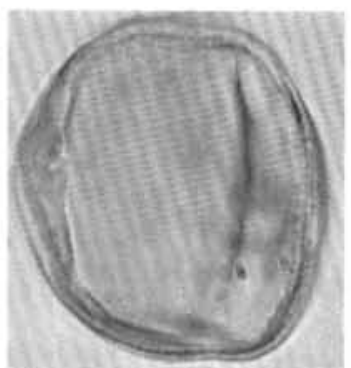

4

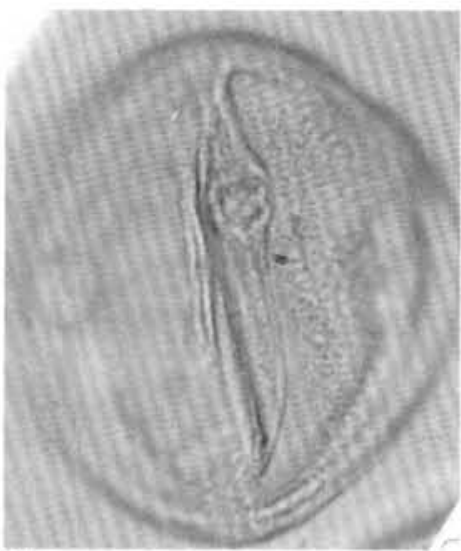

8

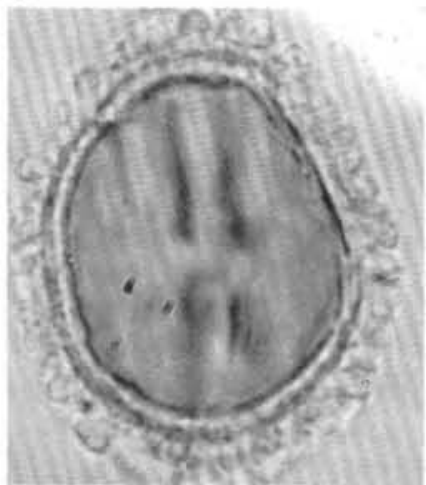

11

5
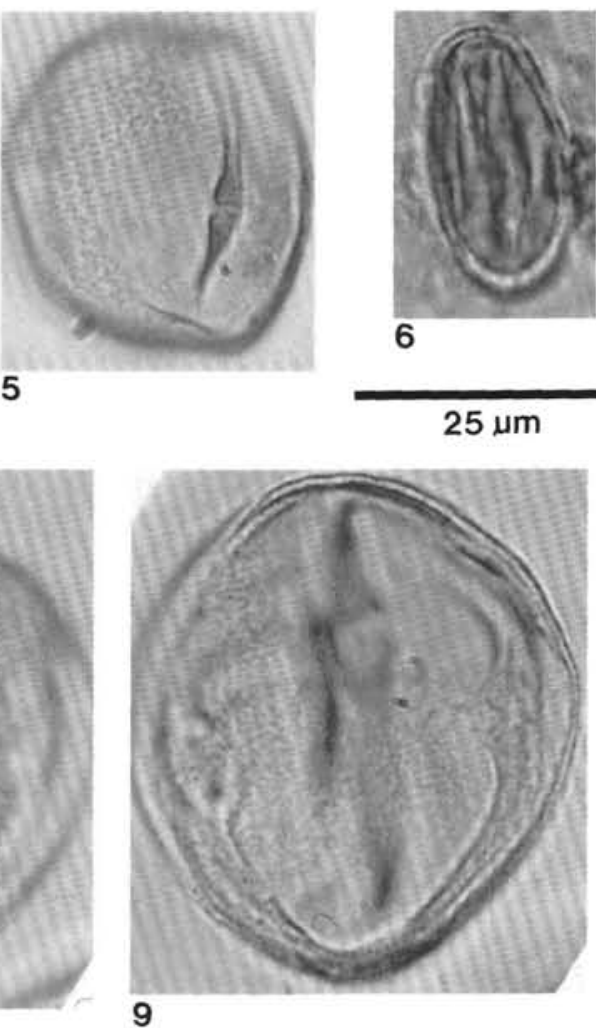

9

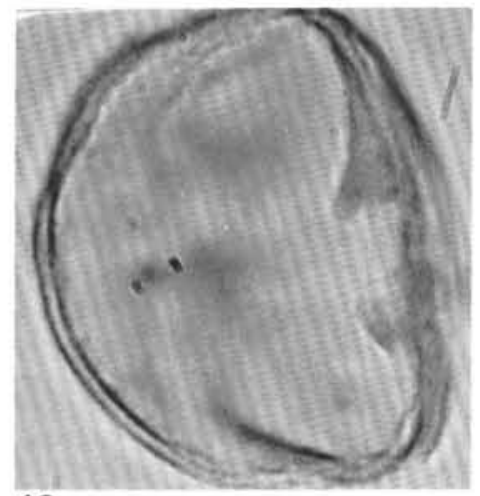

12

6

$25 \mu \mathrm{m}$
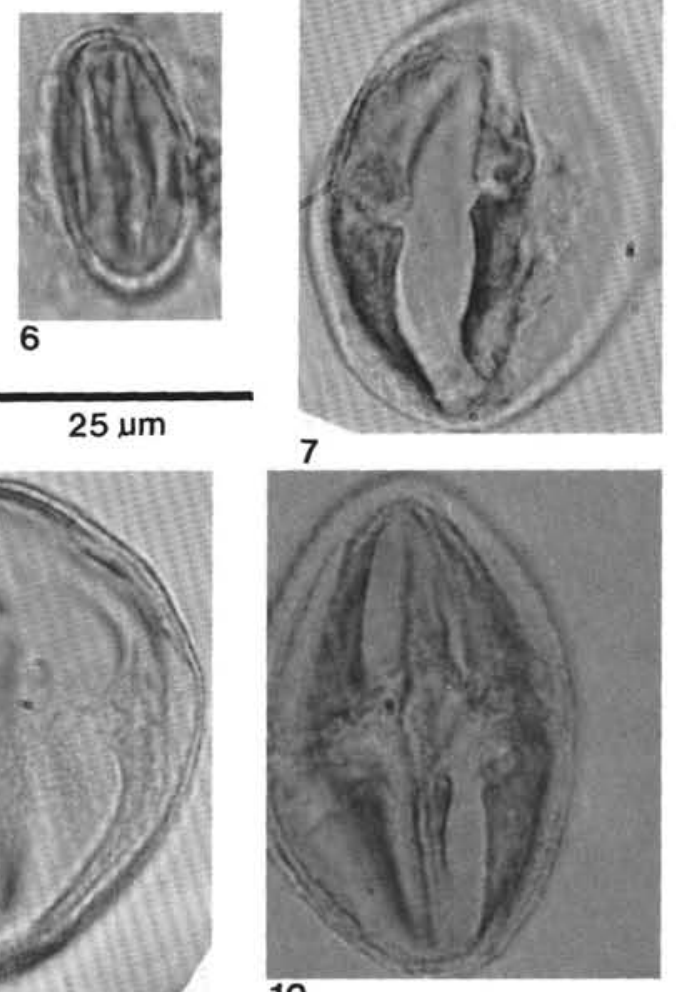

10

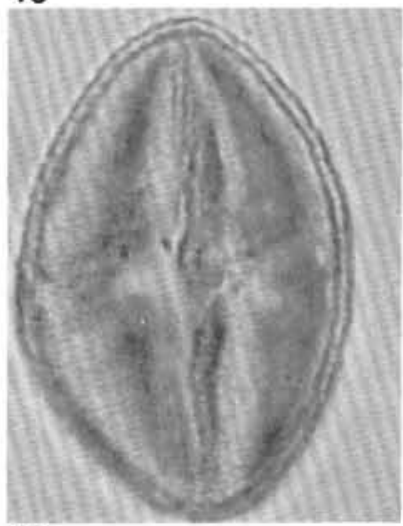

13

Plate 23. (Scale bars $=25 \mu \mathrm{m}$ ) 1-3. LARGE TRICOLPORATES; 104-643A-10-1, $35 \mathrm{~cm}$. 4-5. ROUND TRICOLPORATE; 104-642C-20-7, 67 $\mathrm{cm}$. 6. SMALL TRICOLPATE; 104-642B-21-6, $84 \mathrm{~cm}$. 7-10. LARGE TRICOLPORATES; 104-642B-21-6, $84 \mathrm{~cm}$. 11. CLAVATE TRICOLPORATE; 104-642B-20-6, $84 \mathrm{~cm}$. 12-13. LARGE TRICOLPORATES; 104-642B-21-6, $84 \mathrm{~cm}$. 